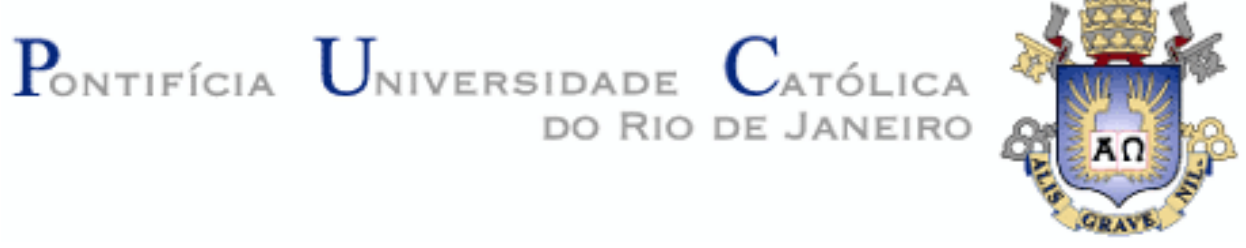

Viviane Aparecida Moreira Silva

"Quando o Espírito de Deus soprou...": A Experiência do Espirito de Deus nas Comunidades

Eclesiais de Base

Dissertação apresentada como requisito parcial para obtenção do grau de Mestre pelo Programa de Pós-graduaçao em Teologia do Departamento de Teologia da PUC-Rio.

Orientador: Prof. Abimar Oliveira de Moraes 
Viviane Aparecida Moreira Silva

\section{"Quando o Espírito de Deus soprou...": A Experiência do Espirito de Deus nas Comunidades Eclesiais de Base}

Dissertação apresentada como requisito parcial para obtenção do grau de Mestre pelo Programa de Pós-Graduação em Teologia do Departamento de Teologia do Centro de Teologia e Ciências Humanas da PUC-Rio. Aprovada pela Comissão Examinadora abaixo assinada.

Prof. Abimar Oliviera de Moraes

Orientador

Departamento de Teologia - PUC-Rio

Prof. Teresa Maria Pompéia Cavalcanti

Departamento de Teologia - PUC-Rio

Prof. Francisco Rodrigues Orofino

ITF

Profa. Monah Winograd

Coordenadora Setorial de Pós-Graduação e Pesquisa do

Centro de Teologia e Ciências Humanas - PUC-Rio

Rio de Janeiro, 25 de agosto de 2016. 
Todos os direitos reservados. É proibida a reprodução total ou parcial do trabalho sem a autorização da universidade, da autora e do orientador.

\section{Viviane A. Moreira Silva}

Bacharel em Teologia pela Pontifícia Universidade Católica do Rio de Janeiro. Foi tutora do curso de iniciação teológica da Pontifícia Universidade Católica do Rio de Janeiro. Foi professora na FAVALE/UEMG, coordenadora de Extensão no NUPEX (Núcleo de Pesquisa e Extensão da FAVALE). Trabalha no Instituto Interdisciplinar de Leitura e Cátedra Unesco de Leitura PUC -Rio no Setor de Comunicação e Tecnologia da Informação e Comunicação. Tem experiência como assessora de CEBs, Pastoral da Juventude e na área de Educação, com ênfase em Educação à Distância, atuando principalmente no seguinte tema: Transdisciplinariedade, Feminismo, Religião e Tecnologia de Informação e Comunicação.

Ficha Catalográfica

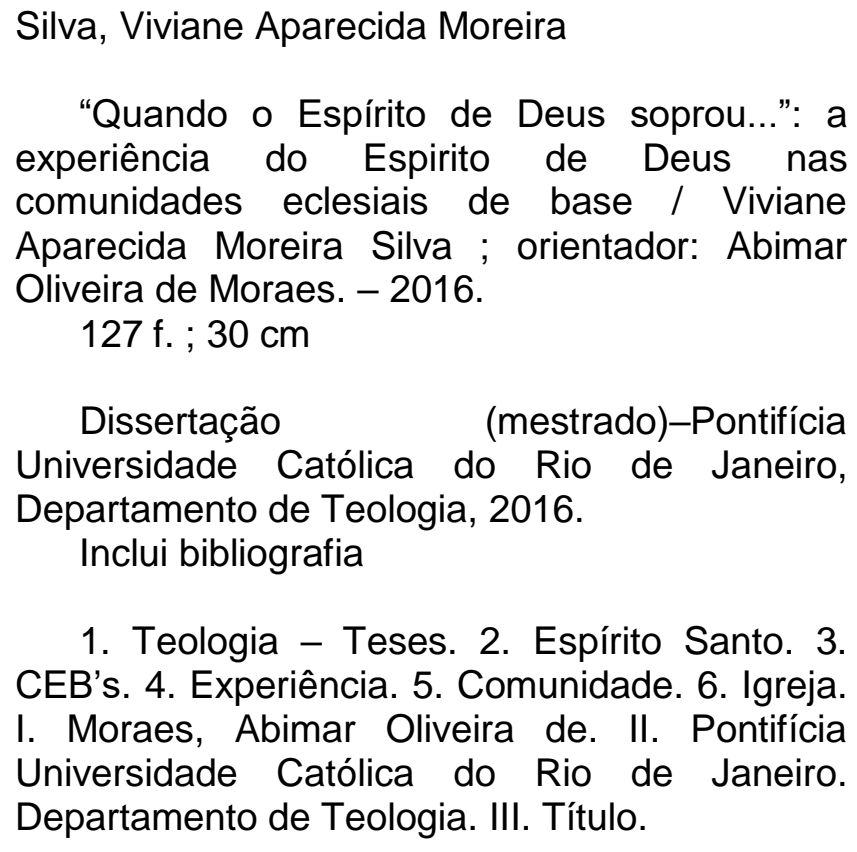

1. Teologia - Teses. 2. Espírito Santo. 3. CEB's. 4. Experiência. 5. Comunidade. 6. Igreja. I. Moraes, Abimar Oliveira de. II. Pontifícia Universidade Católica do Rio de Janeiro. Departamento de Teologia. III. Título. 


\section{Agradecimentos}

Ao orientador, Professor Abimar Oliveira de Moraes pela confiança e por não ter desistido de mim, mesmo quando eu mesma tentei desisitir;

Aos meus irmãos e irmãs, Sérgio Albuquerque, Alexandre Rangel, Alessandro Rocha, Cristiane Sanches e Cristina Furtado, Michele Amaral que me sustentaram na fé, no amor e na vida;

Aos meus pais do coração: José Carlos e Orys; Mãe: valeu pela teimosia e pelos puxões de orelha!

Aos companheiros e companheiras da Cátedra Unesco de Leitura e do iiLer PUCRio, o carinho de vocês que me empoderou e me devolveu a confiança em minha competência.

À Eliana Yunes, amiga, irmã, companheira na fé, na vida e nos projetos, por um mundo melhor,obrigada por ser firme quando eu precisei de força, ser doce quando precisei de consolo e ser sinal quando me perdi no caminho.

À Diocese de Leopoldina onde nasci e cresci, que me enviou ao mundo em missão e me fez conhecer as CEB's pelo Brasil a fora; que me deu a oportunidade de conhecer e conviver com tantos profetas e profetizas; Dom Luciano Mendes, Frei Beto, Leonardo Boff, Carlos Mesters, Teresa Cavalcanti, Julieta Amaral, Nancy Cardoso, Neli de Almeida e tantos outros homens e mulheres cujo testemunho da força no Espírito me conduziu até aqui.

Ao Paráclito, meu companheiro de caminhada, só ele sabe o que foi a experiência de compor este texto, pois foi nele, por ele e com ele que tenho feito essa travessia perigosa e apaixonante que é a vida.

Que Ele permaneça sempre conosco e nós Nele! 


\section{Resumo}

Silva, Viviane Aparecida Moreira; Moraes, Abimar Oliveira de. "Quando o Espírito de Deus soprou...": A Experiência do Espirito de Deus nas Comunidades Eclesiais de Base. Rio de Janeiro, 2016. 127p. Dissertação de Mestrado - Departamento de Teologia, Pontifícia Universidade Católica do Rio de Janeiro.

O presente trabalho tem como objeto de pesquisa as Comunidades Eclesiais de Base (CEB's) a partir de uma perspectiva pneumatológica, considerando a vida cotidiana como o Locus Theologicus da experiência no Espírito de Deus. Sendo o Espirito Santo, sujeito da Palavra, ele é quem possibilita fazer uma experiência cujo início está na proclamação da vida que é revelada por Deus. As CEB's são aqui apresentadas, como espaços onde a experiência do Espírito Santo é vivida sob a luz da justiça, do direito e da igualdade; por isso, como nas comunidades lucanas, ele é a força que fortalece a caminhada, dá coragem na luta (cf. At 2,1-6); é a unção que faz proclamar a libertação dos cativos e o Ano da Graça do Senhor (Lc 4,18-20). Investigam-se os movimentos que prepararam a chegada das CEB's, pois fundam um momento histórico da Igreja do Brasil e propiciam experiências que mudaram a vida de muitos católicos. Destaca-se como as pessoas que estão nas CEB's vivenciam suas experiências de vida à luz do Espírito pela dinâmica do seguimento de Jesus Cristo. Trata-se de uma espiritualidade marcada por um tríplice movimento: êxodo, compromisso e proximidade. Uma dinâmica que começa na sua dimensão histórica, no auto identificação com um Povo; passa pela dimensão comunitária, criando laços de comunhão no seguimento de Jesus e termina na dimensão pessoal, na experiência amorosa de um Deus que nos ama na nossa pobreza. A pesquisa não quis ser um estudo de pneumatologia, mas uma tentativa de uma "eclesiologia da experiência", considerando como ação do Espírito de Deus, dentro desta experiência eclesial, tudo que a move e transforma.

\section{Palavras-chave}

Espírito Santo; CEB's; experiência; comunidade; Igreja; vida cotidiana. 


\section{Résumè}

Silva, Viviane Aparecida Moreira; Moraes, Abimar Oliveira de (Conseiller). “Quand l'Esprit de Dieu insuffla...": L'expérience de l'esprit de Dieu dans les petites communautés chrétiennes. Rio de Janeiro, 2016. 127p. Thèse de Maîtrise - Departamento de Teologia, Pontifícia Universidade Católica do Rio de Janeiro.

Le présent travail a comme objet de recherche les base communautés ecclésiales (CECB) d'un point de vue pneumatológica, compte tenu de la vie quotidienne comme le Locus Theologicus d'expérience dans l'esprit de Dieu. Faisant l'objet de l'Esprit Saint, mot, il est celui qui permet de faire une expérience dont la maison est dans la proclamation de la vie qui nous est révélée par Dieu. Le CECB est présenté ici, en tant qu'espaces où l'expérience de l'Esprit Saint est vécue par la lumière de la Justice, le droit et l'égalité; donc, comme dans les communautés, il est Lucane qui fortifie la marche, prendre le courage dans la lutte (voir 2,1 -6); est l'onction qui proclame la libération des captifs et l'année de grâce du Seigneur (LC. 4.18 -20). Enquêter sur les mouvements qui a préparé l'arrivée du CEB's, se trouvent un moment historique dans l'église du Brésil et fournir des expériences qui ont changé la vie de beaucoup de catholiques. Se distingue comme les gens qui sont dans l'expérience de CECB que les expériences de leur vie à la lumière de l'esprit par la dynamique de suivre le Christ Jésus. Il est d'une spiritualité marquée par un triple mouvement: Exode, engagement et proximité. Une dynamique qui commence dans sa dimension historique, l'identification automatique avec un peuple ; passe par la dimension communautaire, en créant des liens de communion dans la suite de Jésus et se termine par la dimension personnelle, aimer l'expérience d'un Dieu qui nous aime dans notre pauvreté. La recherche ne voulait pas être une étude de pneumatologie, mais une tentative d'une ecclésiologie «d'expérience», vu comment l'esprit de Dieu, dans cette expérience ecclésiale, tout ce qui bouge et se transforme.

\section{Mots clefs}

Esprit-Saint; CECB; l'expérience; Communauté; Église; vie quotidienne. 


\section{Sumário}

1 Introdução 11

2 Gênese das Comunidades Eclesiais de Base (CEB's) 15

$\begin{array}{ll}2.1 \text { A gestação } & 17\end{array}$

2.1.1 A catequese popular de Barra do Pirai $\quad 18$

2.1.2 O Movimento de Natal $\quad 19$

2.1.3 Experiência pastoral de Nísia Floresta 22

2.1.4 Movimento por um Mundo Melhor $\quad 25$

2.1.5 Ação Católica Brasileira 27

2.1.6 Planos de Pastoral da CNBB 32

2.1.6.1 Plano de Emergência (PE) 32

2.1.6.2 Plano de Pastoral de Conjunto (PPC) 33

2.2 Os primeiros passos e aproximação com a Teologia da Libertação 35

2.2.1 A caminhada das CEB's na América Latina 37

2.2.2 A crítica feita pelo Magistério da Igreja 39

2.3 $\mathrm{O}$ que são hoje as Comunidades Eclesiais de Base e seu processo

2.3.1 O amadurecimento 43

3 Experiência no Espírito de Deus $\quad 46$

3.1 Experiência como ponto de partida 46

3.1.2 A Montanha é a Montanha (saber, imanência, identificação) $\quad 47$

3.1.3 A Montanha não é a Montanha (não saber, transcendência, desindentificação) 47

3.1.4 A Montanha é a Montanha (sabor - transparência- identidade) 48

3.2 A experiência de Deus - experiência de vida 49

3.2.1 As múltiplas dimensões da experiência 50

3.2.2 Experiências de situações - limites (dimensão pessoal) 51

3.2.3 Experiências que criam comunhão (dimensão relacional) 53

3.2.4 Experiências que perpassam gerações (dimensão histórica) 54

3.2.5 O Espírito de Deus nas experiências de vida 55

3.3 Experiência do Espírito na Bíblia 57

$\begin{array}{ll}\text { 3.3.1 No Antigo Testamento } & 57\end{array}$

$\begin{array}{ll}\text { 3.3.2 O termo Ruah } & 57\end{array}$

3.3.3 Êxodo - O Espírito que faz ser livre $\quad 59$

3.3.4 Juízes e Juízas - O Espírito que faz a Justiça 61

3.3.5 O Espírito que falou pelos Profetas 62

3.3.6 O Espírito de Deus e sua Shekiná 65

3.4 Experiências do Espírito no Novo Testamento 66

3.4.1 A experiência do Espírito em Jesus 66

$\begin{array}{ll}\text { 3.4.2 A espiritualidade de Jesus } & 68\end{array}$

3.4.3 A Experiência das comunidades primitivas $\quad 70$ 
3.4.3.1 Na dimensão pessoal $\quad 70$

3.4.3.2 Na dimensão coletiva $\quad 71$

3.4.4 A Experiência da comunidade do Discípulo Amado 73

4 A experiência do Espírito de Deus nas CEB's 76

4.1 Dimensão histórica - Povo de Deus congregado pela Palavra $\quad 76$

4.1.1 O Espirito e a Palavra: a leitura da Bíblia como identificação histórica $\quad 79$

4.2 Dimensão comunitária - A comunidade dos seguidores de Jesus 81

4.2.1 A Missão - seguir Jesus 82

4.2.2 A celebração 87

4.3 Dimensão pessoal - O Espírito que liberta 89

4.3.1 Os destinatários do Reino - a libertação dos pobres 90

4.3.2 A espiritualidade da cruz 91

4.3.3 O Espírito e a libertação das mulheres 93

4.4 Os desafios de hoje $\quad 95$

4.4.1 O que e como são as CEB's hoje 96

4.4.2 A Linguagem e a comunicação nas CEB's hoje $\quad 97$

đ 4.4.3 A opção preferencial pelos pobres hoje 99

4.4.4 São ou não as CEB's uma Igreja pneumatológica 101

5 Conclusão 105

6 Referências Bibliográficas $\quad 111$

6.1 Documentos 111

6.2 Livros $\quad 112$

6.3 Artigos 115

Anexo I - Cartilha Mutirão 119

Anexo II - Cartilha Viver é Lutar 123

Anexo III - Jornal de Nízia Floresta (1964) 127 


\section{Listas de Figura}

Figura 1 - Espiral da Ruah por Viviane Moreira 


\section{Abreviaturas}

CEBI Centro de Estudos Bíblicos

CEB's Comunidade Eclesial de Base

CELAM Conselho Episcopal Latino Americano

CNBB Conferência Nacional dos Bispos do Brasil

DA Documento de Aparecida

EG Evangelii Gaudium

ES Espírito Santo

LG Documento Lumen Gentium

MMM Movimento por um Mundo Melhor

QE Quarto Evangelho 


\section{1 \\ Introdução}

Acredito que grande parte dos estudantes de Teologia, quando decidem o tema de sua dissertação, optam por algo que Ihes fale ao coração, ou um assunto que durante o curso despertou sua atenção. Não é o meu caso.

Desde que iniciei o curso de Teologia, sempre houve por parte de professores, colgas de curso e amigos, a expectativa de um dia escrevesse sobre as Comunidades Eclesiais de Base. Não que estas não me fosse caras, mas sempre soube que falar sobre as CEB's seria, na verdade, falar sobre mim mesma.

Nasci na Comunidade Eclesial de Base São Benedito, na Diocese de Leopoldina, Minas Gerais. Já na adolescência, participava dos encontros diocesanos das CEB's, com 19 era da Equipe de Animação Diocesana e logo em seguida da coordenação das CEB's do Leste II (Minas, Rio e Espirito Santo).

Fui da Equipe de Publicação do Cebi-Minas, participei de muitas Assembleias da Ampliada Nacional das CEB's e estive presente em 4 Intereclesiais. Tudo isto me deu a possibilidade de conhecer de perto, Comunidades Eclesiais de Base em todo o país nas décadas de 80 e 90.

Mas esta dissertação não é sobre mim. É sobre estas comunidades que me acolheram, me ensinaram a ser cristã e que, de uma certa forma, me libertaram.

Falar das CEB's aqui e revisitar meu verdadeiro Locus teológicus, é voltar àquela experiência que deu sentido a tudo que sou hoje. Por isso, esta dissertação para mim, é mais que um discurso sobre, é meu atestado de gratidão à todas as comunidades que, com sua luta, sua profecia, sua beleza, me ensinaram a ser igreja viva, a entender que é o Espírito de Deus presente nestas comunidades que liberta as pessoas.

É, portanto, a experiência do Espírito, o lócus teológicus deste trabalho, e isso significa uma ampliação dos espaços onde a vida se faz. Significa que o Espírito de Deus vem ao nosso encontro em muitos momentos de nossas vidas e nos toma sem aviso prévio ou possibilidade de controle, pois não fazemos experiências, nós as vivemos, somos tomados por elas e algumas vezes ao invés de expressá-las, elas é que fazem de nós sua expressão. 
Se somos cristãos, os espaços da experiência do Espírito de Deus em nós, são ainda mais ampliados, pois a vivemos numa via de mão dupla: como Corpo de Cristo e como cristãos que possuem o Espírito de Cristo.

Fazemos a experiência do Espírito "como comunidade", na vida cotidiana, nas lutas pela causa do Reino, na vida sacramental, nas obras de caridade, em tudo que nos faz sentir um "nós". Como comunidade - Corpo de Cristo, organismo vivo que sente as experiências que transformam, edificam, ou dilaceram e estratificam, expressamos ou nós fazemos expressão destas, através da teologia, dos documentos, da reflexão pastoral, do discurso episcopal, por todas as formas onde "nós" comunidade-corpo, se manifeste. Ali onde somos um todo, "sentimos como Igreja" e experienciamos a unidade nos dadas pelo Espírito para viver em comunhão.

Por outro lado, somos pessoas, nossa vida é marcada pelas dores, alegrias, ódios, amores, morte e nascimento, e por estas fazemos uma experiência pessoal no Espírito de Deus. E a Igreja que é cada um de nós, experimenta tudo isso à luz da nossa fé, da nossa individualidade, nossa subjetividade e liberdade. Como não podemos separar quem somos do que somos, nossa leitura da vida e das experiências que vivemos estão submetidas à nossa fé em Jesus Cristo morto e ressuscitado.

Podemos dizer então, que neste momento, sentimos "na comunidade", e quando assim o dizemos não nos referimos a um lugar, mas sim a um estar. Viver essa via de mão dupla, não é tão simples, principalmente para os leigos/as, somente o Espírito Santo de Deus, que move a Igreja e que inhabita em nossos corações pode realizar esta comunhão.

Essa junção entre o sentir da pessoa - sujeito, com sua história e liberdade; com o sentir da comunidade, que carrega consigo o manto da missão, só pode ser costurada pelo Espírito. É ele que une as pessoas nas CEB's e faz do eu de cada um, o nós que segue pelo mundo proclamando a libertação.

Para tentar compreender essa costura, precisamos conhecer os sujeitos que se encontram: O Espírito de Deus e as Comunidades Eclesiais de Base, depois verificar os frutos deste encontro.

O método aqui utilizado não poderia ser outro, além da que mais comum as CEB's: ver, julgar e agir.

No primeiro capitulo, meu leitor e eu nos encontramos com o protagonista desse encontro: o Espirito de Deus.

Vamos ver... 
... como nascem as CEB's, que vendavais o Espirito fez para que estas pudessem existir. Chamamos este capítulo de Gênese das CEB's, pois entendemos que o código genético destas comunidades possui a força de uma série de movimentos, processos históricos que implodiram num caldeirão de mudanças que transformaram não só o panorama eclesial mais também social do nosso país.

... este é um convite a olhar com atenção para o exercício histórico que o Espírito faz para mudar a Igreja e criar condições de possiblidade para que esta se transforme e as CEB's nasçam ...

No segundo capitulo, vamos julgar...

... a luz da pneumatologia de Moltmann vamos encontrar um conceito de experiência que nos ajude a entender as dimensões da experiência do Espírito de Deus na vida humana e na Igreja.

No terceiro capítulo, vamos sentir...

... sentir a ação do Espírito de Deus nessas comunidades, sentir a ação transformadora que liberta e impela a comunidade a luta pela justiça, pela igualdade e o direito. No agir das CEB's um jeito novo de ser Igreja no mundo.

Nas CEB's aprendi a ver luz na escuridão, a ter uma espiritualidade martirial, capaz de enxergar na noite escura a claridade da lua. A viver os desafios cotidianos da comunidade esperando sempre o entardecer. Pois o entardecer traz ao céu, cores e nuances imagináveis. É a hora da conversa com Deus. É então nesse diálogo de suprema e efêmera beleza, que se superam as dores da caminhada. Pois o trajeto do caminho é longo, às vezes os passos são lentos, mais a chegada ao Reino é certa.

Por outro lado, academicamente falando, o tema desta dissertação ainda poderia se abrir a outras frentes de reflexão e pesquisa.

Por exemplo, o desafio das CEB's de falar ao mundo plural e globalizado. Apesar de sua realidade ser ainda substancialmente rural, muitas comunidades de base hoje estão nas periferias dos grandes centros, vivenciando realidades multiculturais diversas, onde a linguagem utilizada nas décadas de 70, 80 e 90, não comunicam mais. Que natureza deveria ter hoje esta linguagem para seguir como catalizadora desta experiência da Ruha?

A questão da opção pelos pobres, ainda é uma temática as ser aprofundada com mais atenção e abertura nas CEB's. Hoje, esta categoria abrange uma gama maior de pessoas vivendo às margens da estrutura social. A dimensão da pobreza passa hoje por camadas ainda mais profundas do tecido social. À multidão dos que nada tem, juntam-se os transexuais, os migrantes, os sem-terra, os exilados 
e tantos outros. Como falar de opção, se muitos descartados nem se veem como pobres?

Por fim há uma problemática com a qual me deparei neste trabalho de pesquisa: a ausência documental. O número de teólogos, padres e bispos que acompanham as CEB's é grande; no entanto, a produção teológica sobre uma experiência que marcou a história eclesiológica da Igreja do Brasil é mínima. Produz-se muito: material de formação de lideranças, subsídios para caminhada, cartilhas para círculos bíblicos e tantos outros materiais populares. Entretanto, poucos fazem uma análise teológica do resultado destas leituras, das experiências registradas destas comunidades.

O tema das CEB's não se esgota nesta dissertação e mereceria que mais pesquisadores se debruçassem sobre o tema. 


\section{2 \\ Gênese das Comunidades Eclesiais de Base (CEB's)}

Um fenômeno novo cria sempre uma nova linguagem e instaura suas próprias categorias para se auto-expressar; assim também as CEB's (Comunidades Eclesiais de Base) deram e continuam dando origem a uma nova eclesiologia e formulando novas questões para a teologia. Mais de 5 décadas se passaram desde o surgimento das primeiras CEB's, mas tudo ainda é muito novo, uma "realidade inacabada". Elas nascem, crescem, se transformam e continuam se auto-transformando nos dias de hoje, de acordo com as realidades que vivem. ${ }^{1}$

Esse processo pluriforme é a dinâmica da história da Igreja, que não é apenas a atualização de uma antiga forma ou repetição de experiências históricas, mas é o vendaval da ação do Espírito que tudo mobiliza, desaloja e põe movimento, este movimento é condição de possibilidade para vivência de um "novo-ainda-não experimentado". ${ }^{2}$

Sob a sinergia do Espírito, vários movimentos surgem nos anos 60, em um contexto de rica fermentação popular onde os movimentos sociais e religiosos floresceram e apontaram para uma compreensão crítica da realidade e a um compromisso com a história. Em 1964, no Brasil, o golpe militar bloqueia este processo iniciado, mas não consegue impedir que as articulações e dinâmicas iniciadas através da Igreja fossem interrompidas.

Nos anos 70, a experiência das CEB's irradia-se por todo país, vivendo um momento de grande vitalidade. A partir dos anos 80, elas enfrentam novos desafios e ao mesmo tempo ampliam novos horizontes, incorporando temas como cultura, etnia, gênero, ecologia, ecumenismo, espiritualidade, etc.

Hoje, quando existem grupos e instituições que apontam o esgotamento das CEB's, Luiz Alberto Gómez de Souza, no seu artigo “As CEB's vão bem, obrigado", nega que as CEB's estejam em declínio e afirma sua vitalidade, pois o importante não é sua maior ou menor presença na mídia; nem elas se descobrem

\footnotetext{
${ }^{1}$ BOFF, Leonardo., Eclesiogênese, p. 19.

2 Tomo emprestado o termo de Leonardo Boff, no livro acima citado, quando este fala da experiência da Igreja como processo sempre em evolução e pluriforme, como será, a seu ver de Cristo à Parusia. Para Boff, a lgreja não vai em linha reta, mas passa pelas variações históricas e culturais "carregando consigo o mundo e ofertando-o a Deus". Ibid.
} 
numa leitura feita a partir das estruturas do poder eclesiástico, mas pela relevância de suas práticas. ${ }^{3}$

As CEB's recuperam, de certa forma, aquela liberdade que os fiéis gozavam no interior da Igreja antes do processo de romanização. ${ }^{4}$ Não surgem do nada. Reencontram as fontes tradicionais e profundas de um catolicismo tradicional naquilo que tinha de original, popular, autônomo, livre. Sob formas novas, respondendo a outras exigências e condições sócio-culturais, assistimos ao aparecimento de leigos líderes que assumem papel relevante na vida eclesial popular. ${ }^{5}$

A Conferência Nacional dos Bispos do Brasil, na $7^{a}$ reunião ordinária do Conselho Permanente, de 23 a 26 de novembro de 1982, em Brasília, DF, no Documento 25 afirma:

Constatamos com alegria que as CEB's abriram um novo e fecundo espaço de participação dos leigos na Igreja. Isso acontece não só pela participação mais ativa que as CEB's oferecem por sua dimensão mais humana e pela proximidade da vida da pessoa, mas também porque propicia uma nova e mais variada distribuição dos vários serviços e ministérios eclesiais. Essa maior participação dos leigos e o surgimento de novos ministérios são dois frutos da maior significação na vida da Igreja. ${ }^{6}$

São comunidades que vivem do espírito de Igreja. Crescem dentro da comunidade universal e recordando os inícios da Evangelização por parte dos Apóstolos, nas pegadas do Mestre Jesus. Não é uma experiência que nasce de uma invenção arbitrária, mas sim pelo Espírito de Deus que está na origem de toda vida. ${ }^{7}$

São espaços onde a experiência do Espírito Santo é vivida sob a luz da justiça, do direito e da igualdade; por isso, como nas comunidades lucanas, o ES é a força que vem do alto para fortalecer na caminhada, para dar coragem na luta

\footnotetext{
3 SOUZA, Luiz Alberto Gómez de. "As CEB's vão bem, obrigado!", p. 107.

${ }^{4}$ Antes do Brasil Império, vivia-se um catolicismo tradicional se referia às tradições lusitanas transplantadas à colônia, marcado pelas devoções e procissões. O espírito do concílio de Trento e sua "aplicação" em toda parte na cristandade, trouxe para o Brasil, um catolicismo renovador acentuava as tradições romanas e o vínculo com a Santa Sé. O catolicismo tradicional apresentava uma dimensão claramente social: em um deserto de emoções, as manifestações religiosas eram verdadeiros oásis, suscitando ocasiões de prolongamentos. Havia, porém, conflitos com respeito a esses "prolongamentos" das festividades religiosas, bem como a certas expressões religiosas populares suspeitas de superstição. Por sua vez, o catolicismo renovado era mais individual e insistia sobre a transformação pessoal, exigindo a regularização dos casamentos para a recepção dos sacramentos. Os laços e relações da Igreja no Brasil com Roma eram bastante tênues, praticamente durante todo o período colonial. De toda sorte, é só a partir da época imperial (1822) que se pode falar de um processo de "romanização". (A noção de romanização do catolicismo brasileiro foi proposta por Roger Bastide e desenvolvida por DELLA CAVA, R., Miracle at Joazeiro, p. 20-23 e n.33, p. 216-217. OLIVEIRA, Pedro Ribeiro., "Catolicismo popular e Romanização do Catolicismo brasileiro", p. 131.

5 TEIXEIRA, Faustino., Comunidades Eclesiais de Base, p. 30.

${ }^{6}$ CNBB., As Comunidades Eclesiais de Base na Igreja do Brasil, p. 3-4.

${ }^{7}$ BARREIRO, Álvaro., Comunidades Eclesiais de Base e Evangelização dos Pobres, p. 9.
} 
(cf. At 2,1-6); ele é a unção para proclamar a libertação dos cativos e o Ano da Graça do Senhor (Lc 4,18-20).

Neste capítulo veremos os movimentos que prepararam a chegada das CEB's, pois fundam um momento histórico da Igreja do Brasil e propiciam experiências que mudaram a vida de muitos católicos. Depois refletiremos sobre como as pessoas que estão nas CEB's vivem as dimensões da experiência no Espírito de Deus.

\title{
2.1
}

\section{A gestação}

Estabelecer com precisão o momento exato do surgimento da primeira CEB's no Brasil é uma tarefa difícil. Raimundo Caramuru afirma que, por volta de 1967, já existia uma dezena dessas comunidades espalhadas pelo país. Em linhas gerais, o contexto eclesial brasileiro e universal contribuiu para a eclosão do fenômeno das CEB's. ${ }^{8}$

\begin{abstract}
A experiência das CEB's não surgiu de um planejamento prévio, mas de um impulso renovador, como um sopro do Espírito, já presente na Igreja no Brasil. Esse impulso renovador se manifesta de forma crescente, sobretudo, nos anos 50 e 60 do século 20. $\mathrm{Na}$ verdade, os tempos se tornaram maduros para uma nova consciência histórica e eclesial, que trouxe consigo um novo sujeito social na sociedade brasileira, um sujeito popular, que ansiava à participação como portador de uma nova consciência na Igreja. Ele ansiava participar ativa e co-responsavelmente da vida e da missão da Igreja. Esse sujeito provoca novas descobertas e conversões pastorais. ${ }^{9}$
\end{abstract}

Podemos, no entanto, elencar alguns movimentos e experiências que antecederam o início das CEB's e são apontados por eclesiólogos/as como percussores desta. São estes: as experiências de catequese popular de Barra do Pirai, o Movimento de Natal com a experiência pastoral de Nísia Floresta e o Movimento de Educação de Base, o Movimento por um Mundo Melhor, a Ação Católica Brasileira e os Planos de Pastoral da CNBB.

\footnotetext{
${ }^{8}$ CARAMURU, Raimundo., Comunidade de Base.

${ }^{9}$ CNBB., As Comunidades Eclesiais de Base na Igreja do Brasil, nำ 7, p. 1
} 


\subsection{1}

\section{A catequese popular de Barra do Pirai}

Em 1956, Dom Agnelo Rossi iniciou em Barra do Piraí um movimento de evangelização para atender a área Diocesana que buscava encontrar um "eficiente e prático meio de defesa da fé", diante da expansão protestante naquele território. A ausência de padres que pudessem atender as comunidades e participar da vida do povo era tamanha que os fiéis se lamentaram, se sentindo abandonados pelas Igreja, como traduz esse depoimento, dado na época a Dom Agnelo por uma fiel: "Senhor Bispo, que humilhação para nós católicos: no Natal as três igrejas protestantes estavam iluminadas e concorridas. Ouvimos seus cânticos... e nossa igreja católica fechada, em trevas... porque não conseguimos padre". ${ }^{10}$

A ausência de sacerdotes e urgência da missão, levaram Dom Agnelo a convocar os leigos para a evangelização. Segundo a pesquisa de Faustino Teixeira, devido à premência da situação, foram excluídas exigências rigorosas quanto a formação pedagógica, técnica e integral dos futuros catequistas. Bastava que estes soubessem ler e tivessem boa vontade, pois a eles/as não cabia fazer comentários sobre as leituras. Para Faustino Teixeira, o fato dos catequistas não poderem comentar as leituras, demonstra a necessidade de controle do clero, para que não houvesse intervenção ideológica dos catequistas populares no processo de evangelização. ${ }^{11}$

A experiência teve início em 28 de outubro de 1956, quando 372 novos catequistas fizeram um juramento durante uma concentração Diocesana. O trabalho dos catequistas populares era o de reunir o povo, no mínimo uma vez por semana, e ler a lição catequética. Em alguns lugares eles faziam as rezas diárias com o povo, como testemunha o próprio Dom Agnelo:

Normalmente, ele faz as rezas diárias: terço, cânticos, alguma leitura espiritual. Reúne aos domingos e dias santos, o povo, que embora longe da Igreja, para o 'domingo sem missa' ou 'a missa sem padre' ou o 'culto católico' e faz o povo acompanhar espiritualmente e coletivamente a missa que o padre está celebrando na matriz. Reza, como o povo, as orações da manhã ou da noite, as novenas, as ladainhas, os meses de maio, junho e etc., os exercícios da Boa Morte e a Via Sacra [...] Agora há alguém que se preocupa em batizar, em caso de necessidade, de

\footnotetext{
10 ROSSI, Dom Agnelo. "Uma experiência de catequese popular". Apud TEIXEIRA, Faustino., Comunidade eclesial de base, p. 55.

11 TEIXEIRA, Faustino., Comunidade eclesial de base., p. 55.
} 
sugerir $\mathrm{o}$ ato de contrição ao moribundo e de assistir espiritualmente o agonizante. Há alguém, que vela pelo bem-estar religioso do povo. ${ }^{12}$

Aos poucos o movimento foi crescendo e em volta dos catequistas surgindo comunidades, que construíram salões comunitários nos morros, vilas e pequenos povoados. Ao invés de se construir capelas cujo custo seria maior, as comunidades optaram por salões comunitários onde a vida da comunidade girava em torno da catequese, dos cursos de corte e costura e ensino. Havia um núcleo responsável por cada salão e este núcleo organizava festas para angariar fundo para a construção e manutenção do salão. Segundo Faustino Teixeira, chegaram a funcionar 475 núcleos na diocese; no entanto é sabido que nem todos conseguiam cumprir rigorosamente o programa traçado. ${ }^{13}$

A experiência de Barra do Pirai, apesar de ter começado dentro de uma perspectiva apologética - defesa do espaço diante do avanço protestante - e ter como objetivo não o reconhecimento do lugar do leigo dentro da Igreja, mas sim a utilização de sua mão de obra pelo clero, abriu espaço para o protagonismo leigo/a, fator essencial à caminhada das CEB's. Além do que a utilização dos salões comunitários, as orações comunitárias e o "culto católico", mesmo a Palavra não podendo ser comentada pelos leigos, vão iniciar uma abertura para aquilo que nas CEB's será muito valorizado que é a liderança leiga.

\subsection{2 \\ O Movimento de Natal}

O chamado Movimento de Natal foi se constituindo em um conjunto de atividades sociais e religiosas desenvolvidas pela Diocese de Natal, a partir de 1948. O Movimento tinha como objetivo sanar os problemas decorrentes do subdesenvolvimento da região e tinha no foco de seus projetos: a educação de base, a transformação global das estruturas políticas, sociais e econômicas e a educação religiosa das populações carentes. ${ }^{14}$

O Movimento teve repercussão no Brasil e no Exterior, em um artigo publicado na Revista Eclesiástica Brasileira, que Pe. Thiago Cloin denominou assim as atividades sócio-religiosas empreendidas pela Arquidiocese de Natal:

\footnotetext{
12 ROSSI, Dom Agnelo. "Uma experiência de catequese popular". Apud TEIXEIRA, Faustino., Comunidade eclesial de base, p. 56.

${ }^{13}$ TEIXEIRA, Faustino., Comunidade eclesial de base, p. 57.

14 Ibid., p. 78.
} 
Bispos e religiosos, leigos e leigas, não apenas brasileiros, mas também estrangeiros (...) afluem, em número sempre maior, à capital do Rio Grande do Norte, para tomar conhecimento daquilo que podemos chamar o "Movimento de Natal" e que constitui sem dúvida nenhuma a mais bem-sucedida experiência pastoral de grande envergadura, em extensão e profundidade, realizada no Brasil. ${ }^{15}$

Alceu Ferrari destaca no seu livro que três momentos foram determinantes para a origem e evolução do Movimento de Natal: "a reunião mensal do clero a partir de 1948, a fundação do SAR (Serviço de Assistência Rural) em 1949 e o treinamento de líderes iniciado em 1952". ${ }^{16}$ O SAR foi criado para dar suporte às atividades do Movimento de Natal e, com ele, dava-se início a atuação no meio rural. Até 1963, seus setores estavam assim agrupados:

a) setores de conscientização e educação: Escolas Radiofônicas e o MEB (Movimento de Educação de Base); Migração; Centros Sociais e Clubes; Treinamento de Líderes; Ensino Médio; Politização, etc.

b) setores de ação imediata: Cooperativismo; Sindicalismo Rural; Colonização; Artesanato e saúde. ${ }^{17}$

O SAR dispunha de equipes volantes que percorriam as cidades do interior prestando orientação à população. Uma série de Semanas Rurais serão organizadas por este órgão a partir de 1951, mobilizando um grande número de leigos e padres. ${ }^{18}$

As primeiras reuniões do clero, realizadas para trocar idéias sobre os trabalhos nas comunidades, tinham a participação de antigos colegas de Seminário e se revestiam de importância fundamental para os acontecimentos posteriores. ${ }^{19}$ Dois destes colegas de seminário teriam iniciado já o caminho que seria trilhado pelo grupo, como relata Alceu Ferrari:

\footnotetext{
'Eram dois Assistentes Eclesiásticos da Ação Católica e dezenas de militantes leigos' preocupados com os problemas sociais. Pe. Nivaldo Monte, em 1944, substituiu seu irmão na função de Assistente da Juventude Feminina Católica (J.F.C.) e do grupo de Senhoras da Ação Católica (S.A.C.); Pe. Eugenio de Araujo Sales preparava a formação da Juventude Masculina Católica (J.M.C.), instalada em outubro de $1945 .{ }^{20}$
}

Os dois sacerdotes, deram início à primeira fase do Movimento que desencadearia uma série de atividades. Na juventude da época, eles encontraram as lideranças de que necessitavam, a estratégia adotada foi mobilizá-la para criar

\footnotetext{
15 CAMARGO, Cândido Procópio Ferreira de., Igreja e Desenvolvimento, p. 74.

${ }^{16}$ FERRARI, Alceu., Igreja e Desenvolvimento, p. 43.57.

17 Ibid.

18 TEIXEIRA, Faustino., Comunidade eclesial de base, p. 78.

${ }^{19}$ Eram seis colegas de Seminário: Eugenio Sales, Nivaldo Monte, Manoel Tavares, Expedito Sobral de Medeiros, Alair Vilar e Pedro Rebouças de Moura.

${ }^{20}$ FERRARI, Alceu., Op. cit., p. 43.57.
} 
respostas aos desafios. A Ação Católica, com seu Ver, julgar e Agir, foi a base metodológica de toda ação.

O alcance e a extensão do Movimento de Natal foram se ampliando, na medida em que as atividades práticas se mostraram bem-sucedidas e se institucionalizaram. "As atividades visaram, além dos fins religiosos, incrementar a vida comunitária, a saúde e a educação". ${ }^{21}$ Trata-se de uma experiência préconciliar que encontrou plena ratificação nos documentos do Concílio Vaticano II.

O primeiro Plano de Pastoral de Conjunto, conhecido como Plano de Emergência e aprovado pela CNBB na V Assembleia Ordinária (1962) como se verá adiante, foi também "inspirado em boa parte na experiência da Arquidiocese de Natal, RN. Áreas de atuação do Plano já eram objeto de atenção do Movimento de Natal como "a paróquia, o ministério sacerdotal, as escolas católicas, a questão das Frentes Agrárias, a Sindicalização Rural e o Movimento de Educação de Base (MEB)", originário das Escolas Radiofônicas. ${ }^{22}$

O Movimento teve como forte expressão o MEB, na sua atuação na luta da sindicalização rural. A sindicalização já era uma preocupação do Movimento desde 1958, mas ganhou força em 1961 com o I Congresso de Trabalhadores Rurais no Rio Grande do Norte. A Diocese de Natal investiu seus esforços na criação de sindicatos rurais por todo o estado. ${ }^{23}$ Por volta de 1963 eram mais de 50.000 sindicalizados em todo estado, participando de cursos e encontros que tinham como objetivo unificar os camponeses e dar-lhes consciência da realidade que os envolvia. ${ }^{24} \mathrm{~A}$ inserção da lgreja local no movimento de sindicalização, gerou conflitos e perseguições por parte de coronéis, proprietários rurais e deputados. Padres e leigos/as foram perseguidos e a Igreja acusada de subversiva. Com golpe de 64 o Movimento de Natal se desorganiza, vários líderes sindicais são presos e o MEB acusado de subversão, sendo sua cartilha "Viver e lutar" (v. Anexo 1 e 2), ${ }^{25}$ escrita por Paulo freire, apreendida na editora. Dom Eugênio Sales chegou a ser acusado na Assembleia legislativa de comunista e subversivo. A partir de então o Movimento começa a entrar em declínio, Dom Eugênio foi transferido para Salvador e Dom Nivaldo Monte, um dos iniciadores

\footnotetext{
${ }^{21}$ CAMARGO, Cândido Procópio Ferreira., Igreja e Desenvolvimento, p. 38

22 BEOZZO, José Oscar., A Igreja do Brasil no Concílio Vaticano II 1959-1965, p. 352.

${ }^{23}$ Segundo Faustino Teixeira, o interesse da Diocese de Natal em investir na criação dos sindicatos também tinha como objetivo neutralizar a ação das ligas camponesas de Francisco Julião.

24 TEIXEIRA, Faustino., Comunidade eclesial de base, p. 81.

${ }^{25}$ Agradecimento ao Centro de Documentação das CEB's Norte que nos enviaram uma cópia da Cartilha Lutar e Viver e da cartilha de alfabetização Mutirão, ambos produzidos pelo MEB.
} 
do Movimento, assume a Diocese de Natal. No entanto, o Movimento passa por uma completa reformulação com ênfase na organização planejada e burocrática. ${ }^{26}$

Para Cândido Procópio, a análise do papel do Movimento de Natal no Nordeste e no Brasil, mostra a importância do papel da Igreja na história política do país:

Sua inovação foi a ação prática e a visão globalizante que exerceu na conjuntura política do país, perplexo pelas alternativas de organização política e social, bem como a viabilidade de uma solução coerente com o pensamento social da Igreja, beneficiada por seu prestígio e organizada sob seu controle. A tomada de consciência da situação econômica e social do Nordeste por parte da Diocese de Natal e dos Bispos da Região contribuiu para sensibilizar todo o país e estimulou uma ação governamental mais responsável. ${ }^{27}$

As CEB's herdam do Movimento de Natal a superação de uma visão fatalista da história, onde as diferenças econômicas e sociais eram vistas como vontade divina. O Movimento se insere na história com uma Igreja voltada para os pobres, para os que vivem em condições de miséria. Também podemos apontar como legado do Movimento, a militância junto aos trabalhadores rurais, as estratégias de formação visando a união e a conscientização político-social-econômica, além de sua contribuição para uma visão de educação libertadora e integral. De todas as importantes iniciativas do Movimento de Natal destacamos duas que a nosso ver serão importantes para o fortalecimento do imaginário das CEB's: a experiência pastoral de Nísia Floresta e o MEB.

\subsection{3 \\ Experiência pastoral de Nísia Floresta}

"Freiras tomaram conta de tudo". Esta é a manchete de um jornal de 31 de julho de 1964 noticiando a experiência inovadora iniciada na Diocese de Natal (v. Anexo 3$)^{28}$ para suprir as necessidades pastorais e a carência de sacerdotes. Dizia Dom Eugênio Salles, numa intervenção, por escrito, no Concílio Vaticano II:

No presente, é de oitenta milhões o número de habitantes do país, e os padres são apenas doze mil, enquanto temos cerca de quarenta mil religiosas (...). Quem não percebe quão nefasta seria a omissão, se não nos dedicarmos a preparar estas magníficas coortes de religiosas e se, uma vez preparadas, não as convocarmos a

\footnotetext{
26 Ibid.

27 CAMARGO, Cândido Procópio Ferreira., Igreja e Desenvolvimento, p. 91 a 92.

${ }^{28} \mathrm{Em}$ anexo uma cópia do jornal local de 31 de julho de 1964 com notícia e fotos do trabalho das irmãs.
} 
colaborarem em todas as obras apostólicas que não são reservadas aos sacerdotes? ${ }^{29}$

Nísia Floresta, município do interior do Rio Grande do Norte, tornou-se a primeira paróquia do mundo a ser entregue a religiosas a partir de 3 de outubro de 1963. Assim, o Movimento de Natal abriu novas perspectivas para o apostolado e as primeiras religiosas assumiram a missão: as Irmãs Missionárias de Jesus Crucificado, em Nísia Floresta; as Irmãs do Imaculado Coração de Maria, em Taipu; as Irmãs do Amor Divino, em São Gonçalo; as “Dammes de Marie”, vindas da Bélgica, em Macau. ${ }^{30}$

Mas, em Nísia Floresta, o apostolado das Irmãs Missionárias, alcançou uma repercussão, que levou muitos setores eclesiásticos a repensar o papel das mulheres na caminhada da Igreja. Não podemos nos esquecer que estamos na década de 60, e o espírito machista dominava claramente o local. Os grupos políticos, poderosos e ambiciosos, se tornariam reféns da animação pastoral e popular que as irmãs exercerão.

Apesar de sua liderança, as religiosas de Nísia Floresta nada queriam com a política, apesar de não se omitirem na educação política de seus paroquianos. ${ }^{31}$ O modo de viver e se manter aparece como testemunho da providência divina. Viviam pobremente. O espírito da congregação falava em consagração a Deus, sem separação do mundo. Seu único objetivo era o apostolado. ${ }^{32}$

Uma das religiosas da equipe de Nísia Floresta era Marlene Pessoa de Lins, com 27 anos. Era a madre da comunidade. Antes tinha sido Marlene militante da Ação Católica nos morros suburbanos de Recife. Estudou na Universidade Católica de Pernambuco. Marlene afirmava que seu ideal de jovem era ser "padre". Somente depois é que entrou no Instituto das Missionárias de Jesus Crucificado, como a escolha melhor que fez em sua vida. ${ }^{33}$

Sobre as Irmãs de Nísia Floresta, Dom Helder em uma de suas correspondências enviadas de Roma ao Palácio São Joaquim, no Rio de Janeiro, dizia se "tratar de uma posição pioneira de Dom Eugênio, quanto à promoção apostólica das Religiosas". ${ }^{34} \mathrm{O}$ texto considerava grande a explosão demográfica do Brasil, e afirmava que além do diaconato permanente, seria bom contar com a legião de Religiosas existente na América Latina, com formação intelectual,

\footnotetext{
29 BEOZZO, José Oscar., A lgreja do Brasil no Concílio Vaticano Il 1959-1965, p. 347.

${ }^{30}$ As Irmãs do Imaculado Coração de Maria iniciaram a missão em Taipu (RN) em 1964.

${ }^{31}$ Freiras tomam conta de tudo, Revista Visão - julho de 1964.

${ }^{32}$ ALVES, Maria Jeane dos Santos., "Cidadania religiosa: uma experiência de religiosas no Nordeste brasileiro", p. 6.

33 Ibid.

${ }^{34}$ CÂMARA, Dom Helder., Correspondência Conciliar, p. 289. Apud ALVES, Maria Jeane dos Santos., Cidadania religiosa, p. 7.
} 
espiritual e apostólica, muito acima dos simples fiéis; cercadas de muito respeito e estima. Diz Dom Helder, que se tem aqui a chave para um movimento de inúmeras Paróquias e Capelas, sem párocos na América Latina ${ }^{35}$.

O texto da Circular de Dom Helder, narrava experiência realizada pelas Irmãs Missionárias de Jesus Crucificado, cuidadosamente escolhidas e preparadas, que se instalaram na paróquia de Nísia Floresta, sob a responsabilidade direta do Ordinário. A petição visava à autorização para que elas distribuíssem a comunhão eucarística. ${ }^{36}$

A carta de Madre Irani, uma das religiosas que mais tarde seria vigária episcopal, datada de 11 de outubro de 1963, fala do entusiasmo da comunidade e das religiosas. O povo prefere a "Missa das Freiras" revela a novidade sentida pela Comunidade. A comunidade religiosa era mantida inteiramente pelo povo, "até as flores para o altar" ${ }^{37}$ As religiosas viviam da ajuda do povo, a paróquia era pobre, e em algumas ocasiões, sem ajuda do povo elas não teriam nem o que comer. ${ }^{38}$

No entanto, as dificuldades não colocavam fim ao entusiasmo das religiosas como conta Dom Helder: "A localidade ganha vida nova. Há uma parte de diversão para o povo. A Irmã é exímia no violão e o povo se delicia com ela". ${ }^{39}$

No campo de cidadania: "Suscitam ao máximo os valores locais tanto para o cooperativismo como para o Clube recreativo..." 40

Em face da experiência de Nísia Floresta, Dom Helder confidenciava profeticamente:

Quem sabe, um dos capítulos do futuro Echange poderia revelar Nísia Floresta e semear a ideia das diaconisas! Eu por mim, iria mais longe ainda: não descubro nenhuma impossibilidade metafísica ou de ordem sobrenatural que impeça à mulher o acesso ao sacerdócio... O dia de hoje - todos Santos em pleno Concílio - convida a audácias (....). ${ }^{41}$

A experiência de Nísia Floresta quebrava o tom machista de uma Igreja, feita quase só de homens. Mais tarde, as Irmãs de Nísia Floresta participarão das reuniões do Clero de Natal, tomando assento no Conselho Presbiterial da

\footnotetext{
$35 \mathrm{lbid}$.

36 lbid.

${ }^{37}$ BASTOS, Irani., Relato da experiência de Nísia Floresta (Mímeo) 1968. Apud ALVES, Maria Jeane dos Santos., Cidadania religiosa, p. 6.

38 Testemunho dado pelas próprias religiosas de Nísia Floresta, no artigo "FREIRAS tomam conta de tudo".

39 CÂMARA, Dom Helder., Correspondência Conciliar, p. 289.

$40 \mathrm{lbid}$.

41 lbid., p. 291.
} 
Arquidiocese. Irmã Neuza assim se exprime: "Isso criou em nós, na equipe, uma certa consciência de valorização da mulher". ${ }^{42}$

Quando Dom Eugênio foi transferido para o Rio de Janeiro fez de uma religiosa vigária episcopal. Madre Irani Bastos, foi a primeira vigária de Nísia Floresta, em Natal, e aceitou o desafio de assumir, em 1964, a primeira paróquia sem padre transformando-a em uma verdadeira comunidade de culto, fé e engajamento social.

A experiência de Nísia Floresta foi ímpar na história da Igreja do Brasil, porque marcou não só a história da discussão sobre o papel da mulher na Igreja, mas também sobre a ação pastoral, a estruturação das paróquias e comunidades e o trabalho com os pobres. É uma pena que este capítulo da história da Igreja no nosso país seja tão pouco conhecido pelos católicos, uma lgreja faz uma experiência de participação e comunhão tão intensa, não poderia continuar a mesma. Assim como o Movimento de Educação de Base, não poderia ter sido esquecido.

Para as CEB's ela um referencial como modelo de protagonismo das mulheres, descentralização do clero e aproximação do povo por meio de uma linguagem mais lúdica e afetuosa. A irmãs de Nízia Floresta apresentaram ao povo daquela cidade, o rosto feminino de Deus.

\subsection{4 \\ Movimento por um Mundo Melhor}

Ao MMM deve-se o importante papel na renovação do clero brasileiro e agilização da atividade pastoral. Seus inúmeros cursos contribuíram para abrir o espaço eclesial brasileiro e para criar uma atmosfera de renovação em todo país. ${ }^{43}$ A criação do MMM deve-se ao Papa Pio XII, ${ }^{44}$ ele deu o nome ao movimento, apontou o espírito que o animaria e o confiou ao padre jesuíta Ricardo Lombardi a missão de levar adiante o movimento. ${ }^{45}$

42 BASTOS, Irani., Relato da experiência de Nísia Floresta (Mímeo) 1968. Apud ALVES, Maria Jeane dos Santos., Cidadania religiosa, p. 9

${ }^{43}$ BOFF, Leonardo., Eclesiogênese, p. 26.

${ }^{44}$ Mesmo diante das controvérsias sobre a posição de Pio XII durante a segunda guerra (para muitos historiadores ele teria sido conivente para com o nazismo), para a lgreja ele assumiu o legado de uma guerra e buscou dar à esta a credibilidade de uma instituição estava junto ao povo, quando todos os outros tinham desaparecido (lembremos a imagem do papa com os braços abertos entre as pessoas em San Lorenzo bairro de Roma após o bombardeio de 1943), preocupado com o que ele agora entendia como o início de um processo de desintegração da sociedade cristã, viu na proposta de Lombardi um recurso para reunir a cristandade.

45 Tudo começou com a visão do Pe. Lombardi, SJ, nos anos finais da Segunda Guerra Mundial, primeiro na Universidade e depois em igrejas, teatros, praças (até pregar para 300 mil pessoas que 
O Movimento se caracterizava pela necessidade de adaptação pastoral da Igreja às exigências do presente e pretendia imprimir um ritmo novo à vida cristã, buscando superar o individualismo e a ineficiente visão católica. Propunha a renovação e contribuiu para remover do cenário eclesial uma série de ambiguidades que dificultavam a unidade de forças e o trabalho conjunto. A perspectiva de renovação do Movimento abriu caminhos na consciência do clero e dos leigos (as), caminhos estes que seriam posteriormente abertos pelo Vaticano II. A proposta de trabalho planificado, incentivou os sacerdotes a trabalhar em equipes, estimulou as propostas de renovação paroquial pautadas por planejamento científico fortaleceu o entrosamento entre congregações e apoiou o trabalho conjunto feito por dioceses. ${ }^{46}$

O Brasil recebeu o MMM com abertura e receptividade o momento forte da implantação do Movimento aconteceu por ocasião do VII Congresso Eucarístico Nacional, realizado em Curitiba em 1960. Nesta ocasião, Pe. Lombardi pregou um retiro para o episcopado em Curitiba. A presença deste sacerdote no Brasil fortaleceu o Movimento que, de 1960 - quando se fundou o secretariado do MMM em São Paulo - a 1962 viu realizados 186 cursos em 50 dioceses e 15 Estados, sendo um para bispos, 52 para sacerdotes, 48 para religiosas, 80 para leigos, 5 para irmãos maristas e 5 para seminaristas. Por volta de 1965, o MMM teria oferecido cerca de 1200 cursos e envolvido mais de 5.000 pessoas. ${ }^{47}$

Os números definitivamente impressionam, se levarmos em conta as limitações tecnológicas da época, e o fato de não estarmos no mundo globalizado em que vivemos hoje, onde a comunicação e o transporte facilitam os acessos e a multiplicação dos processos. Considerável que a equipe de formação contava com apenas 15 pessoas e que ao final de cinco anos, eles chegariam a marca de 1800 cursos, que tendo ativado todos os extratos da vida eclesial: sacerdotes,

se reuniam nas praças diversas ligadas por megafones) para convidar os italianos à conversão e à reconciliação após a terrível experiência da guerra fratricida, anunciando a esperança em Cristo como a resposta ao social e espiritual da humanidade devastada pela guerra. $O$ ápice deste momento pregação veio quando, pelo rádio, 15 milhões de italianos ouviram a pregação da chamada final "Cruzada para um Mundo Melhor", que terminou com a Missa celebrada à meia-noite 07 de dezembro de 1950 pelo Papa Pio XII, enquanto ao mesmo tempo, estavam ligados a todas as igrejas e praças na Itália, ao vivo na rádio. Da Itália, a mensagem passou e, com efeito semelhante, as nações da Europa, incluindo alguns do Oriente, e os da América, do Norte e do Sul. A partir desta mobilização das massas é que começou a articulação nos vários campos da pastoral, como uma resposta às interrogações da Igreja e da sociedade, e então surgiu, conforme o caso, a unidade de diversas iniciativas. Em 10 de fevereiro de 1952, o Papa, em discurso de rádio, expressou o que ficou conhecido como a "Proclamação para um Mundo Melhor", que contou com Pe. Riccardo Lombardi na tarefa difícil de iniciar e animar uma experiência de renovação dentro da Igreja, para que esta pudesse servir, segundo o Movimento, de modelo para a construção de um "mundo melhor" PIO XII., Discorsi e Radiomessaggio di Sua Santità PIO PP. XII Ai Fedeli Romani.

46 TEIXEIRA, Faustino., A Gênese das CEB's no Brasil, p. 112.

47 lbid. 
bispos, religiosos, leigos e também outros movimentos ${ }^{48}$. Podemos afirmar que 0 MMM utilizou de uma bem elaborada estratégia pedagógica para multiplicar seu sopro de renovação no Brasil, e que este sopro deu nova vitalidade às paróquias que puderam assumir o rosto de comunidades vivas e dinâmicas. Comunidades onde os leigos foram ocupando seu lugar como lgreja, tanto na elaboração dos planos de ação como na responsabilidade da execução dos mesmos. ${ }^{49}$

O MMM sempre teve o apoio do episcopado e em 1966, os objetivos do Movimento foram assumidos pela CNBB, na elaboração do Plano de Pastoral de Conjunto (PPC); muitos dos métodos do Movimento serão adotados agora pelo PPC e o clima de esforço planificado, implantado pelos cursos, encontrará nas diretrizes da CNBB um caminho para a pastoral. O MMM deu um forte sentido histórico-social à ação pastoral e estabeleceu uma crítica ao mesmo tempo sincera e respeitosa das estruturas paroquiais envelhecidas. ${ }^{50}$

A experiência do MMM deixa para as CEB's o legado da formação do laicato, a importância de uma metodologia que considere a construção coletiva: padres e leigos juntos para renovar as estruturas paroquiais. Porém, a nosso ver, o maior legado desta experiência é a esperança, pois ela começa com o intuito de chamar o povo à conversão e reconciliação, após uma guerra fratricida.

\subsection{5 \\ Ação Católica Brasileira}

A Ação Católica Brasileira, foi um dos movimentos que propiciaram um clima de abertura eclesial e que contribuíram para uma perspectiva de atuação crítica do laicato. Oficializado no Brasil em 1935 por Dom Leme, ${ }^{51}$ incentivado diretamente por Pio XI e tendo como presidente Alceu Amoroso Lima, foi um movimento que buscou articular a fé com a realidade social. ${ }^{52}$

A Ação Católica Brasileira, adotou em seu início o modelo italiano, que era centralizado, unido e autoritário; se baseava em dioceses, incluía as paróquias e se dividia em quatro grupos de acordo com a idade e o sexo. No seu início,

\footnotetext{
48 BOFF, Leonardo., Eclesiogênese, p. 26.

49 Cf. TEIXEIRA, Faustino., A Gênese das CEB's no Brasil, p. 113.

50 lbid., p. 112-114.

${ }^{51}$ A preocupação e Dom Leme em incentivar as organizações leigas não nasce com a ação católica, já em 1922 ele apoiara a criação do Centro Dom Vital. De 1922 até 1933, o Centro Dom Vital coordenou movimentos leigos, entre os quais a Associação de Universitários Católicos, o Instituto Católico de Estudos Superiores, a Confederação Nacional dos Trabalhadores Católicos etc. Em 1933 grande dos movimentos organizados pelo Centro Dom Vital, passaram a fazer parte da Coligação Católica Brasileira e em 1935, foi reorganizado em torno da Ação Católica.

52 Cf. TEIXEIRA, Faustino., Op. cit., p. 73.
} 
espelhava o rosto conservador da Igreja da época, que até os meados de 1940, tendia a associar o catolicismo com posições políticas de direita. No final da década de 30 , sob a influência da filosofia de Jacques Maritain, ${ }^{53}$ uma mudança de perspectiva foi acontecendo lentamente. Seu livro Humanismo Integral, publicado em 1936, causou forte impacto sobre a intelectualidade católica. ${ }^{54}$

Entre as décadas de 40 e 50, Ação Católica estará toda sob a influência do "humanismo maritainista", 55 marcada por uma visão de uma democracia social cristã, onde a crença na defesa do direito da dignidade humana possibilitaria a construção de um homem novo, uma nova cristandade. Essa teria o bem comum como finalidade e recusaria todo e qualquer modelo autoritário de Estado. Tratase de uma concepção solidarista que vai encontrando espaço no pensamento e na prática dos cristãos da Ação Católica. ${ }^{56}$

Em seu início a Ação Católica foi também marcada pelo culturalismo e pelo intelectualismo da elite. Essa perspectiva culturalista dentro da Igreja foi se desenvolvendo junto aos intelectuais da classe média, que conseguiram reunir jovens universitários em torno do Centro Dom Vital, propiciando a difusão do tomismo, da espiritualidade e mais tarde, do movimento litúrgico. Neste período, além de Jacques Maritain, havia influência de outros autores franceses como: Simone Weil e Gabriel Marcel. ${ }^{57}$

Em 1950, a Ação Católica vive uma reformulação e adota o modelo belga, canadense e francês da Ação Católica Especializada, e passa a contar então com cinco organizações destinadas aos mais jovens: a Juventude Agrária Católica (JAC), formada por jovens do campo; a Juventude Estudantil Católica (JEC), formada por jovens estudantes do ensino médio (secundaristas); a Juventude Operária Católica (JOC), que atuava no meio operário; a Juventude

\footnotetext{
53 Jacques Maritain, literato e filósofo neotomista francês, nasceu em Paris, no ano de 1882. Vinculado na primeira juventude ao socialismo revolucionário, converteu-se ao catolicismo em 1906 , com sua esposa Raíssa, influenciado por Léon Bloy, tornando-se, desde então, o expoente máximo do neotomismo no século XX. Maritain refletiu muito e apaixonadamente sobre a situação da sociedade moderna, sua cultura, seus ideais, sua condição moral, política e religiosa. Como fruto dessas reflexões nasceu a sua célebre teoria do Humanismo Integral, que alcançou ressonância máxima no campo da filosofia político-social. $\mathrm{O}$ arguto pensador cristão faleceu em Toulouse (França), no ano de 1973, após uma profícua existência e uma fértil produção intelectual. QUEIROZ, Álvaro., "Jacques Maritain e o humanismo integral".

54 TEIXEIRA, Faustino., A Gênese das CEB's no Brasil, p. 74.

55 O Humanismo Maritanista apresenta quatro conceitos fundamentais: homem como pessoa, lei natural, direitos humanos e bem-comum. O primeiro conceito fundamental no Humanismo de Jacques Maritain é este: o ser humano é concebido com uma dignidade humana, ou seja, é uma pessoa humana. O ser humano é pessoa por não ser objeto nem animal, mas ser dotado de racionalidade e vontade, e é pessoa humana porque também é dotado de uma individualidade, isto é, forma um todo completo em si, uma vez que possui valores humanos e um espírito digno de respeito e liberdade. MARITAIN, Jacques., Os Direitos do Homem, p. 16.

${ }^{56}$ TEIXEIRA, Faustino., Op. cit., p. 75.

$57 \mathrm{lbid}$.
} 
Universitária Católica (JUC), constituída por estudantes de nível superior e a Juventude Independente Católica (JIC), formada por jovens que não fossem abrangidos pelas organizações anteriores. Dom Helder Câmara, então assistente nacional da Ação Católica, teve um papel fundamental nessa nova estruturação. ${ }^{58}$

Destes movimentos, podemos destacar a JUC e a JEC que foram que aos poucos se afirmando com maior vitalidade. Já os setores adultos, não chegaram a se solidificar, exceto a Ação Católica Operária (ACO), que no final dos anos 60 ganhará uma importância significativa. Podemos dizer que a JOC e sobretudo a JUC, encontraram um efervescente momento político para nascer. Era uma época de democracia liberal que propiciava o debate político e a circulação de idéias. Assim como o Brasil, a juventude descobria a sua realidade, procurava seu futuro e sua missão na construção do País. Na década de 50 o tema do desenvolvimento era fundamental; todos os setores da sociedade estavam voltados para discutir as causas do subdesenvolvimento e a busca de estratégias para superá-lo. É nesse contexto que aparece na Ação Católica a influência de Pe. Lebret, suas idéias sobre a complementariedade entre economia e humanismo, através da solidariedade, da humanização das relações entre indivíduos e classes sociais encontraram um fértil campo nas reflexões da juventude da ação católica. ${ }^{59}$

No início da década de 60 a questão social estava no topo da pauta da JUC:

Como agir para transformar as estruturas vigentes, de modo a poder realizar os valores cristãos na vida social? Quais os dilemas e as implicações desta ação? Estas entre outras questões estarão no centro das discussões dos militantes da JUC. O novo campo de influência já vinha se deslocando de Maritain para Emmanuel Mounier. 60

O personalismo de Mounier vai ajudar os militantes na busca de respostas. Nesta época o tema que vai polarizar as atenções é a questão do "ideal histórico", é preciso julgar a história a partir da fé. O sentido da história deveria ser encontrado através do conhecimento da realidade histórica, por intermédio das ciências sociais, políticas e econômicas.

lluminados pelas ideias de Pe. Lebret e de Emmanuel Mounier, no Congresso de 10 anos da JUC, em Belo Horizonte, os jucistas buscam definir concretamente as diretrizes de um ideal cristão histórico. A equipe jucista do Regional Centro Oeste propunha a participação numa tripla construção libertadora, as chamadas "diretrizes mínimas": a luta contra o subdesenvolvimento, na qual a reforma agrária era um objetivo tático e imediato;

\footnotetext{
58 TEIXEIRA, Faustino., A Gênese das CEB's no Brasil, p. 75.

${ }^{59}$ Cf. Ibid., p. 76-77.

60 Ibid., p. 79.
} 
a independência em relação ao campo de atração do capitalismo, com a tática imediata da luta contra a política egoísta dos monopólios; e a ruptura dos laços coloniais com as metrópolis desenvolvidas. Nas "diretrizes mínimas", via-se que o ideal histórico cristão, era para a JUC um passo importante para a construção do Reino de Deus na história através da luta contra a injustiça. O cristianismo era incompatível com a hierarquia de classes, com o capitalismo e as injustiças sociais. ${ }^{61}$

As diretrizes mínimas levantaram uma forte polêmica no meio católico e os jucistas começaram a ser acusados de heréticos e injuriados, líderes foram denunciados e assistentes substituídos. Mais a posição da JUC diante das questões políticas e sociais foram se tornando mais claras. Em Abril de 1961 vem à tona o Manifesto do Diretório Geral dos Estudantes da Pontifícia Universidade do Rio de Janeiro, enfatizando as contradições do subdesenvolvimento e denunciando a estrutura liberal-burguesa. Da mesma forma que o documento do Centro-Oeste, o manifesto da PUC provocou os ânimos conservadores e mais uma vez não faltaram interrogatórios e perseguições. Os estudantes foram ameaçados de expulsão da Universidade. Em sua defesa, Pe. Henrique Lima Vaz, filósofo jesuíta, cuja concepção de "consciência histórica" já alimentava o pensamento jucista, escreveu o artigo publicado no jornal $O$ Metropolitano: “Jovens cristãos em luta por uma história sem servidões”. Neste artigo Pe. Vaz buscava trazer a interpretação correta do manifesto, mostrava que este repousava "num fundamento teológico inabalável: o realismo da Encarnação e o universalismo da Redenção". ${ }^{62}$

Aos poucos a opção pelo socialismo foi se solidificando entre os jovens militantes, aumentando o conflito com a hierarquia, a ponto das transformações ocorridas na JUC se tornarem pauta importante da reunião conjunta da CNBB e do Secretariado para o Apostolado dos Leigos, em outubro de 1961. Nesta reunião os bispos manifestaram sua preocupação com os rumos da Ação Católica e as tendências nela presentes.

O crescente envolvimento do movimento estudantil na discussão dos problemas nacionais e das chamadas "reformas de base", tais como a reforma agrária, acabou por engendrar a criação de uma organização política desvinculada da Igreja - a Ação Popular, constituída por antigos membros da JUC em 1962. Após o golpe de 64, a Ação Católica foi drasticamente reprimida, a sede da JUC em Belo Horizonte foi invadida, documentos desapareceram, assistentes

61 Cf. TEIXEIRA, Faustino., A Gênese das CEB's no Brasil, p. 80-82.

62 lbid., p. 83-86. 
eclesiásticos deixaram o país, e diante da perseguição política a hierarquia se exime de tomar a defesa do movimento. Poucos são os bispos que tomam a defesa da Ação Católica, por exemplo, Dom Helder Câmara, Dom Cândido Padim e Dom Fernando Gomes. Em 08 de Novembro de 1966 a CNBB publica a dissolução das equipes JUC, JEC e JIC. ${ }^{63}$

A ACB preparou o terreno e abriu espaço para a participação do leigo na política e sua inserção nas lutas sociais. A Ação Católica especializada colocou em prática o método ver-julgar e agir e dinamizou a evangelização no sentido de uma atuação histórica, verdadeiramente transformadora. A consciência histórica do cristão, como cidadão de um mundo que já é hoje, primícia do Reino de Deus, desde que nele se viva a justiça e a igualdade, é contribuição importantíssima para uma Igreja que quer ser sinal deste mesmo Reino. Uma visão unitária da história, uma compreensão de salvação universalizada, assim como o questionamento de qualquer visão dualista que não considere a importância da realidade material, vão abrir horizontes para a luta pela dignidade, pelo trabalho, pela moradia, pela terra, pelo direito de igualdade entre homens e mulheres. Tantas lutas que hoje são assumidas pelas pastorais sociais, movimentos de base e demais organizações da Igreja do Brasil. Não que estas realidades já não estivessem no coração do Evangelho de Jesus Cristo, mas tiveram os jucistas o mérito de reunir pensadores, filosofias e práticas que impulsionaram, em nosso país o tom e a força da proclamação do Evangelho.

Durante o tempo que estivemos na Equipe de Animação do Regional Leste II das CEB's, tivemos a alegria de conhecer vários assessores/as da comunidades que participaram ativamente da Ação Católica: Oscar Beozzo, Luiz Alberto Gomes de Souza e a sua esposa Lucia Ribeiro, Frei Beto e tantos outros que hoje acompanham as CEB's. Na verdade, poucos eram os jovens das CEB's ou da Pastoral da Juventude da década de 90 que não conheciam e admiravam a caminhada deste movimento. Deles herdamos o método que ainda hoje utilizamos não só nas CEB's, mas em muitas pastorais: ver, julgar e agir. O pensamento e a filosofia de Jacques Maritain, Simone Weil, Lebret e Mounier, chegava aos jovens das CEB's nos anos 90 como leite dado a uma criança sendo amamentada. A ação Católica marcou a história da igreja e uma das matriarcas das CEB's.

63 TEIXEIRA, Faustino., A Gênese das CEB's no Brasil, p. 88-94. 


\title{
2.1.6 \\ Planos de Pastoral da CNBB
}

Em consonância às determinações do Vaticano II e na busca de uma nova estrutura que dinamizasse a vida religiosa e uma pastoral mais versátil e adaptada à realidade nacional a CNBB elaborou o Plano de Emergência (1962-1965) e o Plano Pastoral de Conjunto (1966-1970), nos quais se propôs a renovação da antiga pastoral paroquial.

\subsubsection{1 Plano de Emergência (PE)}

O PE buscou a revitalização apostólica dentro de uma perspectiva históricosocial, a partir de uma nova visão eclesiológica. Uma eclesiologia comunitária, onde o trabalho conjunto de todas as forças vivas da Igreja desse suporte à uma renovação que superasse o individualismo apostólico.

\begin{abstract}
Convocamos, pois, todas as forças vivas ${ }^{64}$ da Igreja para um renovado esforço de pastoral que congregue sacerdotes, religiosos e leigos e atinja todas as almas, não só aquelas ovelhas dóceis que vivem já na fidelidade à Santa Igreja, mas ainda as ovelhas arredias e as tresmalhadas, para as quais não faltam senão talvez um convite e uma oportunidade para conhecerem mais de perto a Igreja e os bens que ela oferece em nome de Deus. ${ }^{65}$
\end{abstract}

A convocação é para um trabalho em conjunto, para a vivência de uma Igreja que se concebesse como Corpo Místico de Cristo, como comunidade viva. ${ }^{66}$ Para iniciar essa renovação o PE propõe uma tomada de consciência, através de uma severa autocrítica das deficiências da pastoral anterior. ${ }^{67}$ Aponta a necessidade de uma pastoral de conjunto e lembra a experiência do Movimento de Natal como pioneira nesta busca por uma pastoral mais planejada: "falta-nos planejamento,

\footnotetext{
${ }^{64}$ A convocação aí feita tem sua inspiração na mensagem de João XXIII no Natal de 1961: "Convocamos os homens de todas as classes a realizarem, no mundo do trabalho, dos negócios e das profissões, as diretivas da doutrina social da Igreja. Fugindo do nivelamento liberticida pregado pelo marxismo, não se caia no egoísmo, na cobiça e na desumana indiferença que caracterizam o capitalismo liberal. Hoje não se pode mais errar nem tergiversar. Pois o caminho está aberto e seguro: é a "Mater et Magistra", código completo de convivência humana, impregnado de vida sobrenatural, ensinando-nos que a justiça e a bondade cristã hão de'vencer o espírito de contradição e de dureza, para se conseguir uma valorização mais serena das coisas" (João XXIII, Radio mensagem, Natal de 1961. Apud CNBB., Plano de Emergência para Igreja do Brasil, p. 16.

65 Ibid., p. 15.

${ }^{66}$ TEIXEIRA, Faustino., A Gênese das CEB's no Brasil, p 116.

${ }^{67}$ A criação do CERIS (Centro de Estatística Religiosa e Investigações Sociais) desta tomada de consciência da importância do conhecimento científico da realidade religiosa para realização de uma real autocrítica.
} 
sobretudo de conjunto. Ainda podem ser saudadas como pioneiras as experiências de Campinas, de Ribeirão Preto e do Nordeste (em torno de Natal)". 68

Embora ainda não se faça referência as CEB's, o PE valoriza as comunidades naturais já presentes na grande comunidade paroquial, tais comunidades são vistas como possibilidade de maior vivência da vida comunitária. Na proposta da renovação paroquial também está presente a transformação da diocese, unidade fundamental de ação pastoral. ${ }^{69}$

O Plano de Emergência, mesmo com limitações, como a ausência da participação das bases na sua elaboração, o fato de nem todos os bispos que o votaram terem-no acolhido, algumas falhas de sistematização e técnicas de planejamento, foi inegavelmente importante para Igreja do Brasil por ter contribuído para a renovação das estruturas pastorais e seu quadro de ação. Foi a primeira tentativa de pastoral de conjunto no Brasil, desafio que ainda hoje mobiliza a prática pastoral da Igreja e suscita novas respostas à teologia pastoral.

\subsubsection{2 \\ Plano de Pastoral de Conjunto (PPC)}

Tão logo se concluiu o Concílio Vaticano II, a Igreja do Brasil já havia preparado o Plano de Pastoral de Conjunto, para colocar em prática, na ação pastoral, as orientações e diretrizes conciliares. Elaborado com uma técnica de planejamento adequada e inovadora e abrangência teológica o PPC, publicado no início de 1966, revolucionou o modo de fazer pastoral no Brasil e deu nova estrutura à Conferência Nacional dos Bispos do Brasil. ${ }^{70}$

Com o propósito de criar meios e condições para que a lgreja no Brasil se ajustasse "o mais rápida e plenamente possível à imagem de Igreja do Vaticano II", ${ }^{71}$ o PPC, partindo dos principais documentos do Concílio, estabeleceu "seis linhas fundamentais de ação, em torno das quais devia estruturar-se toda a ação pastoral". 72

Desse modo a Constituição Dogmática Lumen Gentium, documento conciliar sobre a Igreja, inspirou a primeira linha de trabalho, dedicada a "promover [...] plena unidade visível no seio da Igreja Católica". ${ }^{73}$ A segunda linha, que visava

\footnotetext{
${ }^{68}$ CNBB., Plano de Emergência para Igreja do Brasil, p. 21.

69 Cf. TEIXEIRA, Faustino., A Gênese das CEB's no Brasil, p. 116-117.

${ }^{70}$ CNBB., Plano de pastoral de conjunto.

71 lbid., p. 29.

72 GODOY, Manuel José de., "A CNBB e o processo de evangelização do Brasil”, p. 389.

${ }^{73}$ CNBB., Plano de pastoral de conjunto, p. 63-74
} 
"promover a ação missionária", ${ }^{74}$ embasava-se no Decreto Ad Gentes, sobre a atividade missionária da Igreja no mundo. "Promover a ação catequética, o aprofundamento doutrinal e a reflexão teológica" ${ }^{\prime 75}$ era o objetivo da terceira linha de trabalho pastoral, tendo como base a Constituição Dogmática Dei Verbum, sobre a revelação divina. A quarta linha de trabalho, dedicada a "promover a ação litúrgica", ${ }^{76}$ fundamentava-se na Constituição Sacrosanctum Concilium, sobre a sagrada liturgia. O Decreto Unitatis Redintegratio sobre o ecumenismo e a Declaração Nostra Aetate, sobre as relações da Igreja com as religiões nãocristãs, foram o fundamento para a quinta linha de trabalho pastoral dedicada a "promover a ação ecumênica"77 e, por fim, a Constituição Pastoral Gaudium et Spes sobre a Igreja no mundo inspirava a sexta linha de ação, cuja preocupação era "promover a [...] inserção do Povo de Deus, como fermento, na construção de um mundo segundo os desígnios de Deus". ${ }^{78}$

O Plano de Pastoral de Conjunto contribuiu também para uma descentralização maior da Igreja do Brasil, expandindo de sete para treze o número de regionais da CNBB, bem como ampliando os secretariados de pastoral de oito para doze. "Ao mesmo tempo em que se regionalizava, a CNBB potenciava seus instrumentos de ação em âmbito nacional".$^{79}$ Pouco antes da promulgação do PPC, em Assembléia Geral no final de 1964, foram aprovados os novos estatutos da CNBB, adequando as estruturas da Conferência às indicações conciliares.

O PPC conseguiu realizar uma série de perspectivas pastorais como desenvolvimentos eclesiológicos que não passavam de intuições germinais no PE. A importância das comunidades aparece com mais clareza e perspectiva no Documento:

Nossas paróquias atuais deveriam ser compostas de várias comunidades de base, dada sua extensão e densidade demográfica e percentagem de batizados a elas pertencentes de direito. Será de grande importância empreender a renovação paroquial pela criação dessas comunidades de base. A matriz será, pouco a pouco, uma dessas comunidades, e o pároco presidirá todas as que se encontram na porção do rebanho que lhe confiado. ${ }^{80}$

O Plano de Pastoral da CNBB e o Plano de Emergência, contribuíram para o incentivo das CEB's, pois suas propostas de renovação paroquial ministerial e

\footnotetext{
74 CNBB., Plano de pastoral de conjunto, p. 75-79.

75 Ibid., p. 80-85.

76 lbid., p. 86-96.

77 lbid., p. 97-100.

78 lbid., 101-110.

79 BEOZZO, José Oscar., "A recepção do Vaticano II na Igreja do Brasil”, p. 444.

${ }^{80}$ CNBB., Plano de Pastoral Conjunto, p. 58.
} 
educacional, incentivaram a presença da lgreja no campo sócio-econômico e deram os primeiros passos para uma maior aproximação das bases e das forças vivas da Igreja no sentido de co-responsabilidade e comunhão. ${ }^{81}$

Em torno da Mater et Magistra (1961) ${ }^{82}$ e da Pacem in Terris $(1963)^{83}$, dos Documentos Conciliares, a Igreja buscou uma nova atuação. No nosso continente esse processo ganharia grande impulso com as releituras que as Conferências de Medellin (1968) e Puebla (1979) fariam da realidade social. Nascia assim, o compromisso da Igreja com o mundo dos pobres. A maneira de realizar este compromisso descerrou-se o apoio às nascentes comunidades de base, os bispos latino-americanos tiveram o mérito de tornar as CEB's em um instrumento de ação da Igreja no continente.

A gestação das CEB's no Brasil verdadeiramente começa com estes dois planos, o compromisso com a descentralização, o convite a criar comunidades de base, o compromisso com os pobres, eram uma proclamação da necessidade das CEB's existirem.

\section{2 \\ Os primeiros passos e aproximação com a Teologia da Libertação}

Estes movimentos contribuíram em diferentes níveis para o fenômeno das CEB's. Enquanto que uns ajudaram a criar um espaço de renovação eclesial, outros, acentuadamente a Ação Católica, abriram o caminho para a reflexão crítica da mensagem teológica e do compromisso político. ${ }^{84}$

Tais movimentos lançaram as primeiras sementes de uma compreensão crítica do evangelho e da incidência da fé na história. Criaram as condições para a redefinição da atuação crítica dos cristãos no interior da igreja e da sociedade brasileira, apontando questões-chaves que prenunciaram e anteciparam os temas que emergiriam em seguida com a teologia da libertação e as comunidades eclesiais de base. O golpe militar de 1964 e seus desdobramentos posteriores bloqueou este

81 TEIXEIRA, Faustino., A Gênese das CEB's no Brasil, p. 115.

82 Mater et Magistra é a Carta-Encíclica do Papa João XXIII sobre a recente evolução da Questão Social à luz da Doutrina Cristã. Foi publicada em 15 de maio de 1961, no septuagésimo aniversário da Encíclica Rerum Novarum e no terceiro ano do pontificado de João XXIII. Esta encíclica é considerada um marco importante da Doutrina Social da Igreja, porque, através de uma profunda leitura dos novos "sinais dos tempos", atualizou as orientações das encíclicas sociais anteriores (a partir da Rerum Novarum de Leão XIII), dando assim a resposta católica para os problemas temporais da época. Ela serviu também de base para vários documentos pontifícios sobre as questões sociais que a sucederam e que ainda hoje se mantém atual, tais como as encíclicas Pacem in Terris, Populorum Progressio e Humanae Vitae.

83 Pacem in Terris a Carta-Encíclica do Papa João XXIII sobre "a Paz de todos os povos na base da Verdade, Justiça, Caridade e Liberdade". Foi publicada no dia 11 de abril de 1963, dois meses antes da morte de João XXIII, dois anos depois da construção do Muro de Berlim e alguns meses depois da Crise dos Mísseis em Cuba.

84 SOARES, Paulo Célio. "CEB's", p. 73. 
processo, mas não impediu a dinâmica de rearticulação da pastoral popular na periferia das grandes cidades e no âmbito rural. As CEB's nascem nesta difícil conjuntura política, nas áreas sociais mais carentes, como pequena "flor sem defesa", de forma simples e despojada, suscitando a afirmação da palavra dos pobres e excluídos a partir da reflexão bíblica. ${ }^{85}$

Como já dissemos é difícil determinar com exatidão a eclosão das primeiras CEB's. Entretanto, pode-se afirmar que foi mesmo a partir do Concílio Vaticano II (1962-1965), e no contexto do amplo movimento popular que sacudiu o Brasil na década de 60, que a experiência ganhou foro de cidadania. Os diversos relatórios elaborados em função dos encontros Intereclesiais de CEB's no Brasil, indicam que o processo forte de sua irradiação no país, veio no bojo de todo o contexto de renovação religiosa propiciado pelo Vaticano II. Porém não podemos nos esquecer que o nascimento de uma nova teologia que daria bases sólidas para o crescimento das CEB's: a Teologia da Libertação.

CEB's e Teologia da libertação estão "geneticamente" ligadas. A temática da libertação surgiu na América Latina e no Brasil, no início da década de 60, também no contexto do debate do fenômeno do subdesenvolvimento. Já haviam sido superadas duas interpretações equivocadas e consideradas insuficientes: do subdesenvolvimento como atraso técnico (países em via de subdesenvolvimento) e subdesenvolvimento como interdependência desigual das partes de um mesmo sistema (países desenvolvidos/ países subdesenvolvidos). Havia-se chegado à conclusão de que o subdesenvolvimento era, outra face do desenvolvimento, como um sistema de dependência de centros hegemônicos. ${ }^{86}$

Os países ricos se desenvolviam às custas dos mais pobres, criando uma relação de dependência para com estes. Essa descoberta suscitava a denúncia e a indignação diante de um sistema de opressão que se alimentava da dependência e do subdesenvolvimento dos mais pobres. Essa nova interpretação não ficou apenas na teoria, mas começou a alimentar práticas sendo desenvolvidas por aqueles movimentos que abordamos anteriormente.

Não podemos nos esquecer que esta foi uma época de ebulição do diálogo entre Igreja e sociedade, entre a fé cristã e os anelos de transformações e de libertação a partir das classes populares. A atmosfera de liberdade e criatividade que marcara o Vaticano II se espalhara pela América Latina encorajando teólogos a pensarem questões pastorais a partir da realidade em que vivem. Tanto teólogos católicos como Gustavo Gutiérrez, Juan Luís Segundo, Lucio Guerra; do lado protestante, Emílio Castro, Júlio de Santa Ana, Rubem Alves e José Miguez

85 TEIXEIRA, Faustino., "Comunidades Eclesiais de Base no Brasil".

86 BOFF, Leonardo; BOFF, Clodovis., Da Libertação, p. 23. 
Bonino, começavam a aprofundar as reflexões sobre a relação entre fé e pobreza, evangelho e justiça social.

Os textos produzidos pela ação popular no Brasil, a respeito da necessidade do ideal histórico cristão (Pe. Almery Bezerra, Pe. Henrique de Lima Vaz, o documento do DCE-Puc) já prenunciavam a Teologia da Libertação. ${ }^{87} \mathrm{Em}$ Dezembro de 1971, Gustavo Gutierrez o livro inaugural desta teologia: Teologia da Libertação, perspectivas. Anteriormente, em Maio do mesmo ano Hugo Assmann publicava o livro coletivo Opressión-liberación: desafio de los cristianos, e em Dezembro Leonardo Boff terminava em forma de artigos o seu Jesus Cristo Libertador. $^{88}$ Inaugurava-se assim a trajetória de uma teologia feita a partir da periferia e articulada com as questões desta periferia. Questões estas que eram e continuam sendo um desafio para a lgreja.

Os irmãos, Leonardo e Clodovis Boff, comparam a Teologia da Libertação a uma árvore cujos galhos são os teólogos da libertação, a parte mais visível da árvore. O tronco, que é a reflexão dos pastores e demais agentes é pouco percebido, e menos ainda se vê as raízes por debaixo da terra, que é a vida concreta das comunidades. ${ }^{89}$ Mas são elas que sustentam toda árvore, a experiência de milhares de pessoas que vivem e pensam sua fé em chave libertadora.

\subsection{1 \\ A caminhada das CEB's na América Latina}

Nos demais países da América Latina, as CEB's (denominadas Comunidades Cristianas de Base) surgiram um pouco mais tarde, incentivadas pelo clima eclesial que se seguiu à Conferência de Medellín e posteriormente confirmado no encontro de Puebla (1979). As CEB's ganharão também força expressiva em outros países, além do Brasil, como México, Equador, Nicarágua, El Salvador, Chile, Peru e Paraguai.

Na Conferência de Medellín (1968) elas serão chamadas de Comunidades Cristãs de Base:

Assim, a comunidade cristã de base é o primeiro e fundamental núcleo eclesial, que deve, em seu próprio nível, responsabilizar-se pela riqueza e expansão da fé, como também pelo culto que é sua expressão. É ela, portanto, célula inicial de

\footnotetext{
${ }^{87}$ BOFF, Leonardo., Como fazer teologia da libertação, p. 97.

88 Cf. lbid. p. 98.

${ }^{89}$ Cf. lbid., p. 25.
} 
estruturação eclesial e foco de evangelização e atualmente fator primordial de promoção humana e desenvolvimento ( Medellín 15 III A)..$^{90}$

É a partir dos anos 70, a experiência se espalha por todo o Brasil, vivendo um momento de grande vitalidade. A busca de uma igreja renovada, que pudesse assumir os problemas, as dificuldades e as alegrias dos empobrecidos, garantia o testemunho que as fazia crescer e multiplicar pelo país a fora. As CEB's querem ser comunidades adultas, comprometidas com Jesus Cristo, mas igualmente com o povo e a sua libertação; comunidades animadas pelo Espírito e marcadas pela vida de comunhão e de ajuda fraterna. ${ }^{91}$

Em 1975, o Papa Paulo VI, na exortação apostólica Evangelii Nuntiandi, número 58, sublinhou que as CEB's possuem uma base de caráter "nitidamente eclesial e não meramente sociológico ou outro". Ele prossegue afirmando que "elas brotam e desenvolvem-se no interior da Igreja, são solidárias com a vida da mesma Igreja, são alimentadas pela sua doutrina e conservam-se unidas aos seus pastores". O Papa afirma ainda que a vocação fundamental das Comunidades Eclesiais de Base é a de "serem ouvintes do Evangelho que Ihes é anunciado e destinatárias privilegiadas da evangelização, tornando-se anunciadoras do Evangelho. ${ }^{92}$

Neste período surgem os encontros Intereclesiais de CEB's, que foram fundamentais para o amadurecimento e incremento da experiência. ${ }^{93}$ Estes encontros, iniciados no Brasil em 1975, visavam à partilha das experiências, da vida e reflexão presentes nas comunidades espalhadas por este imenso país.

${ }^{90}$ CELAM., Conclusões das Conferências do Rio de Janeiro, de Medellin, Puebla e Santo Domingo, p. 211.

91 TEIXEIRA, Faustino., Comunidades Eclesiais de Base no Brasil, p. 5.

${ }^{22}$ PAULO VI., Evangelii Nuntiandi.

${ }^{93}$ Os Intereclesiais e seus temas, retratam bem o processo de crescimento e evolução das CEB's no Brasil. 10 Intereclesial: Aconteceu na cidade de Vitória (ES), de 06 a 08 de janeiro de 1975, com o tema: "Uma Igreja que nasce do Povo pelo Espírito de Deus". $2^{\circ}$ Intereclesial: Também realizado na cidade de Vitória (ES), de 29 de julho a 10 de agosto de 1976, com o tema: "Igreja, Povo que caminha. $3^{\circ}$ Intereclesial: Foi em João Pessoa (PB), de 19 a 23 de julho de 1978, com o tema: "Igreja, Povo que se liberta". $4^{\circ}$ Intereclesial: Aconteceu em Itaici (SP), de 20 a 24 de abril de 1981, com o tema: "Igreja, Povo Oprimido que se organiza para a Libertação". $5^{\circ}$ Intereclesial: Foi em Canindé (CE), de 04 a 08 de julho de 1983, com o tema: "Igreja, Povo Unido, Semente de uma Nova Sociedade". $6^{\circ}$ Intereclesial: Trindade (Goiás), 21 a 25 de Julho de 1986. Com o Tema: CEB's, povo de Deus em busca da terra prometida. $7^{\circ}$ Intereclesial: Foi em Duque de Caxias (RJ), de 10 a 14 de julho de 1989, com o tema: "Povo de Deus na América Latina, a Caminho da Libertação. $8^{\circ}$ Intereclesial: Aconteceu em Santa Maria (RS), de 08 a 12 de setembro de 1992, com o tema: "Povo de Deus, renascendo das Culturas Oprimidas. 9o Intereclesial: Aconteceu em São Luiz (MA), de 15 a 19 de julho de 1997, com o tema: "CEB's, Vida e Esperança nas Massas". 10 Intereclesial: Foi em llhéus (BA), de 11 a 15 de julho de 2000, com o tema: "CEB's, Povo de Deus, 2000 Anos de Caminhada". $11^{\circ}$ Intereclesial: Teve lugar em Ipatinga (MG), de 19 a 23 de julho de 2005, com o tema: "CEB's, Espiritualidade Libertadora. Seguir Jesus no Compromisso com os Excluídos". $12^{\circ}$ Intereclesial: Aconteceu em Porto Velho (RO), de 21 a 25 de julho de 2009, com o tema: "CEB's: Ecologia e Missão. Do Ventre da Terra, o Grito que vem da Amazônia". O $13^{\circ}$ Intereclesial das CEB's: Aconteceu, de 07 a 11 de janeiro de 2014, em Crato (CE). Esse Encontro teve como tema: "Justiça e Profecia a Serviço da Vida. CEB's, Romeiras do Reino no Campo e na Cidade". MUNDO E MISSÃO. "CEB's: Comunidades Eclesiais de Base". 
Os Intereclesiais, além de espaço privilegiado da partilha de experiências e reflexões das comunidades de base, constituem-se também em rico manancial de animação da vida das CEB's. No espaço "onde elas labutam, pequenas e frágeis, podem sentir-se isoladas e desanimar. Os Intereclesiais revelam para os participantes e pelas informações, notícias e vídeos a muitas CEB's que se trata de enorme rede de CEB's. Pertencem-se mutuamente. Isso anima-as, reforça-Ihes a consciência, a esperança e o entusiasmo. Em termos sociológicos, é uma estrutura de apoio, um 'aparelho de conversa' maravilhoso de reforço da consciência de eclesialidade das pequenas comunidades. ${ }^{94}$

Os primeiros Intereclesiais vão, sobretudo o terceiro na Paraíba, afirmar a identidade das CEB's como Igreja Libertadora. Lá no capítulo III do documento final da Conferência de Puebla (1979), que expressa a situação eclesial da época, o item 96 diz:

As comunidades eclesiais de base que, em 1968, eram apenas uma experiência incipiente, amadureceram e multiplicaram-se, sobretudo em alguns países. Em comunhão com os seus bispos e como o pedia Medellin, converteram-se em centros de evangelização e em motores de libertação e de desenvolvimento. ${ }^{95}$

$\mathrm{Na}$ década de 80 as CEB's viverão fortes interpelações diante das mudanças do cenário político e eclesial, e terão que discutir o tema da identidade eclesial. Os ventos da conjuntura eclesial internacional, não sopravam a favor desta experiência, as CEB's terão que amadurecer sua identidade como lgreja e os Intereclesiais, mais uma vez serão espaço propício para o pensar e avaliar da caminhada.

\subsection{2}

\section{A crítica feita pelo Magistério da Igreja}

As crítica às CEB's tinham como objeto, especificamente a Teologia da Libertação. As duas instruções ,da Congregação para a Doutrina da Fé, publicadas nos anos 1990: a Instructio de quibusdam rationibus "Theologiae Liberationis" (Instrução sobre alguns aspectos da "Teologia Da Libertação") de agosto de 1984 e a Instructio de libertate christiana et liberatione (Instrução sobre a liberdade cristã e a libertação) de março de 1986 não rejeitaram a Teologia da Libertação. Naquele momento histórico , o comunismo soviético era muito presente e existiam muitas pressões dessa ideologia e podemos dizer que o "lugar teológico" da europa não era o mesmo da América Latina.

\footnotetext{
94 TEIXEIRA, Faustino., "Intereclesiais das CEB's".

${ }^{95}$ CELAM., Conclusões das Conferências do Rio de Janeiro, de Medellin, Puebla e Santo Domingo, p. 314.
} 
No prefácio da instrução de 1984, o então Cardeal Joseph Ratzinger, prefeito já dizia qual era a preocupação do Magistério da Igreja:

A presente Instrução tem uma finalidade mais precisa e mais limitada: quer chamar a atenção dos pastores, dos teólogos e de todos os fiéis, para os desvios e perigos de desvio, prejudiciais à fé e à vida cristã, inerentes a certas formas da teologia da libertação que usam, de maneira insuficientemente crítica, conceitos assumidos de diversas correntes do pensamento marxista. ${ }^{96}$

O medo do marxissismo imcopreendia o que seria realmente a nossa realidade social, onde a falta do pão tornava difícil e porque não dizer impossível o anúncio de um Deus que ama a todos:

O sentimento angustiante da urgência dos problemas não pode levar a perder de vista o essencial, nem fazer esquecer a resposta de Jesus ao Tentador (Mt 4, 4): «Não só de pão vive o homem, mas de toda palavra que procede da boca de Deus» (Dt 8, 3). Assim, sucede que alguns, diante da urgência de repartir o pão, são tentados a colocar entre parênteses e a adiar para amanhã a evangelização: primeiro o pão, a Palavra mais tarde. É um erro fatal separar as duas coisas, até chegar a opô-las. O senso cristão, aliás, espontaneamente sugere a muitos que façam uma e outra. ${ }^{97}$

Instrução de 1984 continha várias restrições e fortes críticas a Teologia da Libertação, e no Brasil, em muitas regiões, as tensões entre leigos, clero e episcopado foi atenuada dado o caráter tão negativo da instrução. No entanto em agosto de 1986, a mensagem pessoal de João Paulo II aos bispos brasileiros, Liberdade Cristã e Libertação, tinha um tom mais sereno, chegando a afirmar que a "Teologia da Libertação, não era apenas oportuna mais útil e necessária". 98

No mesmo ano a Congregação para a Doutrina da Fé lançou a Instrução sobre a liberdade cristã e a libertação, em harmonia com o papa e com um tom mais positivo em relação a Teologia da Libertação.

Porém o "silêncio obsequioso" dado a Lenardo Boff em 1985, o desentendimento (para não chamar de perseguição) de muitos padres e animadores das CEB's trouxe uma enorme tristeza as lideranças das Comunidades. Sentimo-nos desamparados pela própria mãe. A Igreja que é o Corpo de Cristo, sofre quando seus membros são feridos e até mesmo amputados. $^{99}$

\footnotetext{
96 SAGRADA CONGREGAÇÃO PARA A DOUTRINA DA FÉ, Instrução sobre alguns aspectos da teologia da libertação.

97 Ibid., n, 03, VI.

98 JOÃO PAULO II, Carta do papa à CNBB sobre a missão da Igreja e a Teologia da Libertação, p. 91.

${ }^{99}$ Lembro do meu primeiro Intereclesial, em Santa Maria (RS), 1992, quando ouvia nos grupos de trabalho 0 testemunho de tantas lideranças que eram perseguidas em suas dioceses, por seus bispos e padres. Lembro-me bem do testemunho de um padre da Arquidiocese do Rio de Janeiro, que estava lá clandestinamente, pois a Arquidiocese não participava dos intereclesiais, dele dizer
} 


\section{3 \\ O que são hoje as Comunidades Eclesiais de Base e seu processo de amadurecimento}

Existem muitas formas de comunidade; as CEB's se denominam de base, 0 quer dizer composta de pessoas dos extratos mais baixos na escala social (pobres, indígenas, negros, mulheres marginalizadas, desempregados), grupo que constituem a parte majoritária da Igreja que são os leigos. Denominam-se, também eclesiais, o que as identifica como Igreja e as difere das demais comunidades. ${ }^{100}$

Aqui o eclesial, aparece como adjetivo qualitativo do substantivo comunidade. Porém para a eclesiologia, o adjetivo (eclesial) é mais importante que o substantivo (comunidade), porque é o princípio constituinte e estruturante da comunidade. "A comunidade eclesial se constitui como resposta à fé cristã e como resultado do apelo evangélico à conversão e à salvação". ${ }^{101}$

Constituímos Igreja, quando em resposta ao apelo salvífico feito em Jesus Cristo, nos reunimos em comunidade, professamos a mesma fé, celebramos a mesma libertação escatológica e tentamos viver o seguimento de Jesus Cristo. Segundo Leonardo Boff, é essa consciência eclesial que nos possibilita falar de Igreja num sentido próprio.

Estamos reunidos e perseguimos objetivos sociais e libertadores porque reagimos ao apelo de Cristo e das outras comunidades que o transmitiram a nós ao nos antecederem na vivência da fé comunitária. Por isso, só poderemos chamar de eclesial uma comunidade se ela apresentar essa explicitação religiosa e cristã. ${ }^{102}$

Portanto, mesmo que uma comunidade viva os valores cristãos, que realize ontologicamente a essência da Igreja, para que essa possa ser considerada eclesial, é preciso haver a consciência dessa realidade ôntico-eclesial e a profissão de fé em Jesus Cristo morto e ressuscitado. ${ }^{103}$

As CEB's possuem essa consciência e vivem sua profissão de fé no ressuscitado por meio da práxis do amor, da fraternidade e da justiça. Motivadas pela fé, as pessoas vivem em comum-união, dividem o pouco que têm e lutam juntas pelo direito de todos terem aquilo que é necessário à vida. Se sentem parte

que "antes a tortura da ditadura do que a perseguição da Igreja Mãe". O termo perseguição é forte, eu sei. Mas era assim que as pessoas se sentiam: perseguidas.

100 BOFF, Leonardo., Eclesiogênese, p. 39.

101 lbid.

102 lbid., p. 41

103 lbid. 
da Igreja Universal, ligadas aos bispos e ao clero desta mesma Igreja, ainda que muitas vezes, hajam divergências entre estas, elas primam pela unidade e o amor à Igreja de Cristo.

Como Igreja, as CEB's também estão sob influxo do Espírito e vivem as mudanças e transformações históricas, sem contudo, perder aquilo que é essencial à toda Igreja que é o próprio Jesus Cristo e a salvação nele oferecida. Num processo de inculturação da fé, cada Ceb é Igreja na sua territorialidade, vivenciado o seguimento de Jesus e sendo sinal para o mundo.

Mesmo que se tenha certa dificuldade em encontrar traços homogêneos e constantes em todas as CEB's, há alguns elementos que, em geral, podem ser detectados. Maria Clara Bingemer destaca quatro elementos: ${ }^{104}$

- territorialidade, isto é, as pessoas de uma comunidade estão situadas num território geográfico específico. É muito fácil que se conheçam e que estabeleçam relações e contatos.

- leitura e a reflexão sobre a Palavra de Deus é outro traço característico das CEB's. Muitas comunidades começaram como reuniões bíblicas que iluminavam a vida das pessoas. À medida em que a vida comunitária se organizava foi introduzido também o culto dominical ou a celebração da Eucaristia.

- participação e a discussão dos problemas em forma de assembleia que caracterizou muitas Comunidades de Base. A metodologia participativa incluiu a colaboração de todos na discussão, na solução e no encaminhamento concreto dos problemas.

- o crescimento e a emergência de ministérios leigos que foram se multiplicando a partir das exigências da comunidade: há ministros da Palavra, ministros da Eucaristia, ministros da pastoral da moradia, do trabalho, do menor. Muitos serviços englobam mulheres e homens em clubes e pequenas organizações: hortas comunitárias, clubes de mães, alfabetização de adultos e, muitas vezes, grupos de sustentação dos movimentos populares. ${ }^{105}$

Esses serviços destacam o compromisso das CEB's com os mais pobres e a relação consequente entre fé professada e vida concreta. É propriamente o compromisso com as camadas mais desfavorecidas da população que tornaram

104 BINGEMER, Maria Clara., "Comunidades Eclesiais de Base”. 105 lbid. 
as CEB's profundamente ativas no campo social. O pobre não é visto como problema, mas como solução no processo de construir uma nova sociedade.

As CEB's são portanto, comunidades missionárias e ecumênicas, isto é, abertas ao diferente, aos pobres e excluídos, às diversas culturas e religiões e até mesmo aos que não têm fé, mas trabalham e lutam pela justiça. Na libertação de todo preconceito e discriminação, as CEB's estarão sempre dispostas ao diálogo, na busca de novos caminhos que superem as enormes barreiras e contradições sociais, para construir o Reino de Deus na solidariedade, na justiça, no amor e na paz.

Elas são, ainda hoje, uma forma de vivência comunitária capaz de responder à alguns desafios que nos são apresentados pela sociedade atual. Em conflito com a realidade social, a Igreja da América Latina encontra nas CEB's uma das possibilidades de ser sinal em um mundo crucificado.

No Documento de Aparecida nota-se a conflitividade da realidade social e eclesial da América Latina, onde a Igreja é desafiada a ouvir os clamores do povo. Um dos grandes desafios que aparece é de tornar a lgreja discípula e missionária a partir de Jesus Cristo. Os bispos declaram:

\footnotetext{
Comprometemo-nos a trabalhar para que a nossa Igreja Latino-americana e Caribenha continue sendo, com maior afinco, companheira de caminho de nossos irmãos mais pobres, inclusive até o martírio. Hoje queremos ratificar e potencializar a opção preferencial pelos pobres feita nas Conferências anteriores. Que seja preferencial implica que deva atravessar todas as nossas estruturas e prioridades pastorais. A Igreja Latino-americana é chamada a ser sacramento de amor, solidariedade e justiça entre nossos povos (DA, 396). ${ }^{106}$
}

Com a organização dos pobres se fortalece a esperança de outra Igreja e outro mundo possível e necessário. Desse modo vão entrando em cena novos sujeitos sociais, como as mulheres, os povos indígenas, os afro-americanos, os catadores de materiais recicláveis entre outros. Nas CEB's esses novos sujeitos sociais encontram espaço para viver uma experiência de Deus que poderá vir a transformar suas vidas e a realidade que os cerca.

\subsection{1 \\ 0 amadurecimento}

A busca pela maturidade eclesial das CEB's, pode ser compreendida pela evolução do termo "ser Igreja" nas CEB's. Poderíamos afirmar que o "sentir" como

106 CELAM., Documento de Aparecida, n. 396, p. 174. 
Igreja nas CEB's foi amadurecendo no decorrer do seu amadurecimento. Três momentos marcam esse processo, o primeiro se dá com o Documento 25 da CNBB (1982):

Fenômeno estritamente eclesial, as CEB's em nosso país nasceram no seio da Igreja-instituição e tornaram-se "um novo modo de ser lgreja". Pode-se afirmar que é ao redor delas que se desenvolve, e se desenvolverá cada vez mais, no futuro, a ação pastoral e evangelizadora da Igreja. ${ }^{107}$

O segundo momento acontece com o VI Encontro Intereclesial das CEB's, em Trindade, Goiás, em 1986, onde se cunhou a expressão - "CEB's: Um modo novo de toda a Igreja ser". Visa-se com tal expressão mostrar que o espírito das CEB's deveria fermentar toda a instituição eclesial a partir da opção pelos pobres. O terceiro momento pode ser compreendido a partir da feliz expressão de D. Pedro Casaldáliga - CEB's: O modo normal de toda a Igreja ser. Esta expressão quer significar que as questões fundamentais defendidas pelas CEB's, devem ser assimiladas por toda a Igreja-instituição, pois fazem parte da defesa da vida.

Esse último momento se dá a partir dos novos horizontes e desafios, que surgem no fim da década de 80 e início da de 90. Desafios estes que foram despontando e ampliando o campo de interesse das comunidades, como os temas da cultura, etnia, gênero, subjetividade, ecologia, espiritualidade, ecumenismo, diálogo inter-religioso etc.

São temas complexos que vão ampliando sua visão, exigindo nova reflexão e disponibilidade, mas que se inserem dialeticamente, sem ruptura, na dinâmica das opções irrenunciáveis que traduzem o universo das CEB's. Para Faustino Teixeira, a ampliação de horizontes não significou uma perda de vitalidade das comunidades, estas continuam "vivas e a caminho".

A dureza e a conflitividade que acompanham o avanço neoliberal, bem como a retração eclesiástica, podem provocar aqui ou ali uma certa "desaceleração", mas isto não significa uma perda de vitalidade da experiência. Os diversos encontros regionais das CEB's e os relatos divulgados pelos animadores de todo o Brasil manifestam a presença de um dinamismo real, só captado por aqueles que acompanham de perto a experiência e que acreditam na força de sua espiritualidade. ${ }^{108}$

Essem dinamismo é o legado deixado por aquelas experincias que estão no DNA das CEB's. Experiências que deixaram uma marca no território de

107 CNBB, As Comunidades Eclesiais de Base na Igreja do Brasil, 끄 3 .

108 TEIXEIRA, Faustino., Comunidades Eclesiais de Base no Brasil, p. 48. 
passagem, que é a Igreja. E que fizeram das CEB's um mosaico, carregado da cor e da história que deu origem à um novo sujeito eclesial.

Afirmar o sopro do Espírito atuante no nascimento e na vida das CEB's, cujas contribuições são inúmeras para a Igreja, não significa a ausência de equívocos na mesma. Porque o Espírito sempre age na história, em pessoas concretas, por isso, limitadas, a recepção desta ação não está ausente de possíveis distorções.

É sempre importante relembrar que o Espírito nunca age num vazio histórico sociocultural, o que significa afirmar que toda e qualquer realidade impregnada da ação do Espírito está sujeita a não captar o modo pleno o seu agir. E por isso talvez historicamente não se tenha entendido sua ação sob as CEB's.

Para melhor entedermos a experiência do Espírito de Deus nas CEB's, necessitamos de um conceito experiência que nos possibilite nos abrir a sua ação no comum da vida, no cotidiano, lá onde Deus "arma sua tenda". 


\section{3 Experiência no Espírito de Deus}

\section{1 Experiência como ponto de partida}

Ter a experiência como ponto de partida é uma tarefa de muitas formas arriscada, principalmente tendo como pano de fundo o discurso teológico, como afirma o teólogo Mário França de Miranda, pois essa sempre derrota o conceito que a quer domesticar no sistema racional. E se pretendemos falar de uma experiência "teológica", vamos considerar o fenômeno da experiência do Espírito na perspectiva de Deus. O que é um desafio, pois sendo, mais propriamente, uma experiência da ação do Espírito e considerando-se que, em Deus, ser e agir se identificam, teríamos, portanto, que entender e expressar o próprio Deus. ${ }^{109}$ Complica-se ainda mais se dissermos que, temos a compreensão total de Deus. Porque então, Deus deixa de ser Deus, como nos lembra Santo Agostinho:

Por mais altos que sejam os voos do pensamento, Deus está ainda para além. Se compreendeste, não é Deus. Se imaginaste compreender, compreendestes não Deus, mas apenas uma representação de Deus. Se tens a impressão de quase têlo compreendido, então fostes enganados por tua própria reflexão. ${ }^{110}$

Leonardo Boff, em seu livro "Experimentar Deus: a transparência de todas as coisas, ${ }^{111}$ usa três metáforas que nos ajudam a compreender a complexidade e a dificuldade que temos ao descrever nossa experiência de Deus. Três etapas que podemos vivenciar na difícil tarefa de entender e comunicar nossa experiência em Deus.

109 MIRANDA, Mário França., "A Experiência do Espírito Santo".

110 Cf. AGOSTINHO, Santo., A Trindade. Sermão 52, n. 16: PL 38, 360.

111 BOFF, Leonardo., Experimentar Deus, p. 13. 


\subsection{2}

\section{A Montanha é a Montanha (saber, imanência, identificação)}

No primeiro momento da experiência, sempre damos nomes a Deus: Pai, Mãe, Santo, Forte, Senhor, Rocha Firme, Rei dos Reis e tantos outros que podemos encontrar na caminhada do Povo de Deus. ${ }^{112}$ Não temos ainda consciência de que tentamos representar o que não pode ser representado, e não nos damos conta ao descrever que vivenciamos, o que descrevemos é a nossa realidade.

Por isso, tentamos aproximar aquela experiência afável, àquilo que nos é conhecido, que nos é palpável e que nos dá uma certa segurança. Tentamos enquadrá-lo dentro dos nossos conceitos, regras, doutrinas e dogmas. Pensamos saber que o que vivemos é o que conhecemos: a Montanha é a Montanha.

\subsection{3 \\ A Montanha não é a Montanha (não saber, transcendência, desindentificação)}

No segundo momento percebemos que tanto as imagens como a linguagem são insuficientes para falar da experiência que Nele vivemos. Tudo que dizemos, o dizemos por analogia, é precário, é limitado. ${ }^{113}$ Se dizemos que Ele é bondade, como conciliá-lo com a maldade e a injustiça presente no mundo criado? Se dizemos que Ele é Pai e Mãe, como conectá-lo a milhares de crianças que estão nas ruas, que não têm família ou ainda que foram violentadas e abandonadas por seus pais e mães? O que fazemos? Dizemos que Deus é um Pai maior? Melhor?

Como dizer que Ele é justiça para uma mãe que tem seu filho levado, assassinado pela milícia, pelo tráfico de drogas ou por "bala perdida"? Vamos dizer que sua justiça não está neste "mundo"?

Como nos lembra Leonardo Boff, não se trata de um "pai melhor", uma “justiça maior" e sim de ser Outro. O totalmente Outro, que está para além das nossas imagens, da nossa linguagem, e que quando ficamos presos às imagens e símbolos que para Ele criamos, nós nos enclausuramos em nossos frágeis conceitos e acabamos por limitar a experiência que Nele vivemos. A Montanha não é a Montanha! 


\subsection{4}

\section{A Montanha é a Montanha (sabor - transparência- identidade)}

Num terceiro momento percebemos que apesar de nossas imagens e linguagens serem limitadas, precisamos delas para nos expressar e dar sentido à nossa experiência de Deus. ${ }^{114}$ No entanto, temos a consciência de que são apenas analogias, são nuances da misericórdia, do amor, da justiça de Deus. Usamos as imagens, mas somos livres delas, pois sabemos que, quando olhamos com mais profundidade, podemos ver que Deus está em todas coisas, sem 0 confundir com elas. Então tudo se torna transparente. Quem está neste momento assume tudo na vida como experiência de Deus. As alegrias, as tristezas, as conquistas, as derrotas, toda realidade humana é envolvida pela graça. A Montanha é a Montanha.

É importante como Leonardo Boff realça o fato de que, no primeiro momento temos uma identificação, em que comparamos a experiência de Deus com aquelas experiências mais próximas de amor e segurança que possuímos. $\mathrm{Na}$ verdade o que reconhecemos são as nuances da presença de Deus em nós.

No segundo momento temos a perda da identificação e começamos a nos questionar sobre a experiência que acreditamos ter em Deus, questionamos nossa fé e a ação de Deus em nossas vidas.

E no terceiro momento temos a identidade, aceitamos que Deus é Ele mesmo e que, por mais profundo e importante que tenha sido nosso primeiro despertar para experiência de Deus, ela não esgota tudo o que podemos viver ainda em Deus. Pois ele é sempre mais do que aquilo que podemos apreender. ${ }^{115}$

Se por um lado temos que compreender que nossa experiência de Deus é sempre limitada, mediada pela linguagem, pela cultura, pelo próprio mundo no qual Ele reina e habita, também é verdadeira a afirmação de que Deus atua na História e que essa ação captada pelos seres humanos, pervade toda a Bíblia.

Ao se refratar no humano, esta ação divina nos poderá ser acessível indiretamente pelos seus efeitos na estrutura complexa e plural do ser humano. Daí a possibilidade de serem elaborados múltiplos e diferenciados discursos sobre os efeitos desta atuação.

\footnotetext{
114 BOFF, Leonardo., Experimentar Deus, p. 15.

115 No dicionário latino-português identidade é "ae qualitas, quod idem super est", semelhança; igualdade; reconhecimento de que o indivíduo é o próprio. Enquanto identificação é "assimulatio"; reconhecimento. Verbetes identidade e identificação. TORRINHA, Francisco. Dicionário Português - Latino.
} 
Nosso discurso teológico deve partir, como os outros, das consequências da presença atuante do Espírito, só que pode ser compreendida em seu próprio nível epistemológico. ${ }^{116} \mathrm{E}$ esse conhecimento deve partir do testemunho daqueles e daquelas que primeiro nos comunicaram sua experiência, como nos aponta o teólogo Jürgen Moltmann:

As palavras da Bíblia, que chegaram até nós através dos séculos, e as palavras de anúncio dos cristãos que ouvimos hoje, não procedem elas de experiências do Espírito semelhantes a esta? Não existem palavras de Deus sem experiências humanas do Espírito de Deus. Por isso, também as palavras de anúncio da Bíblia e da Igreja devem estar referidas às experiências dos homens atuais, para que estes não se tornem apenas "ouvintes da palavra" (K. Rahner), mas também sejam eles próprios os que proferem a palavra. ${ }^{117}$

As experiências no ES vão além da palavra, da linguagem, elas são variadas como é a própria realidade do sensível. Mas o ES é sujeito da Palavra, ele é quem nos possibilita fazer uma experiência que tem seu início na proclamação da vida que nos é revelada por Deus. Todas as experiências que vamos vivenciando ao longo da história salvífica careceram de palavras que possam transmitir a força da vida que vem arando os campos da humanidade, plantando sementes de esperança, colhendo os frutos da fé e nos preparando para o grande banquete do Reino.

Palavras se misturam a lágrimas, sons e gemidos, ecoam na expressão daqueles/as que tentam comunicar ao mundo suas experiências vividas sob a força do Espírito de Deus. Para ouvir estas palavras, estes testemunhos, primeiramente precisaremos buscar um conceito de experiência que possa nos ajudar a compreender a amplitude deste evento na vida de cada cristão.

\section{2}

\section{A experiência de Deus - experiência de vida}

Em sua obra O Espírito da vida, Moltmann nos convida a pensar a partir de uma pneumatologia trinitária, que parte da experiência e da teologia do ES.

Para ele a Teologia da revelação é a teologia da lgreja, a teologia produzida pelos pastores e padres. A experiência como ponto de partida é a teologia de todos /as - ou, como ele afirma, "teologia de leigos/as" -, e isso significa uma ampliação dos espaços onde a vida se faz e se refaz; significa estender os

\footnotetext{
116 MIRANDA, Mário França., "A Experiência do Espírito Santo".
}

117 MOLTMANN, Jürgen., O Espírito da Vida, p. 15. 
espaços de comunhão com o Espírito. Para ele, experiência de vida é experiência de Deus. Ou seja, toda experiência cotidiana resguarda um fundo transcendente; é como se vida fosse então o outro nome de Deus, assim, celebrar a vida é celebrar a Deus. ${ }^{118}$

Moltmann adota o conceito de "experiência do Espírito" na busca de abranger assim a situação intermediária de toda experiência histórica entre o passado e o futuro. Para ele as experiências de Deus podem ser tão intensas, que pode superar o tempo, as razões do acontecer, tudo passa a ser preenchido pela "divina presença"119. É o momento místico, escatológico, onde o tempo de Deus e o tempo dos seres humanos se fundem em Kairós.

\subsection{1 \\ As múltiplas dimensões da experiência}

Toda experiência de vida necessita ser expressa por quem a vive, e ela é manifestada nas palavras, nos símbolos, nos ritos ou até mesmo no corpo de quem a vive. Se a pessoa não a expressa ela fica , como diz Moltmann, "atravessada na pessoa", ${ }^{120}$ é na expressão da experiência que o sujeito passional mostra sua força sobre a mesma. Na expressão se encontra a realização criadora da vida, e a experiência de um se torna visível aos olhos do outro.

Seguindo a lógica do pensamento ocidental , onde o ser humano (varão) é sujeito de razão e vontade, a expressão deve ser o fruto dessa razão e aí, sensibilidade e corporeidade são secundários. No entanto a maioria das experiências que fazemos, e aqui vale lembrar que estamos nos referindo as experiências de vida, aquelas que nos irrompem e nos tomam; não as fazemos com a consciência ou com a razão. Elas nos tocam por inteiro: corpo e alma, atingem o núcleo do nosso ser, em camadas que desconhecemos, de um modo que muitas vezes somente uma pequena parte destas experiências conseguem ser racionalizadas, refletidas ou interpretadas. ${ }^{121}$

Quantas vezes não somos tomados por experiências que não foram suscitadas por nós e que nos tomam por inteiro. É claro que razão e consciência também estão presentes em muitas experiências, mas elas vão além , e nossa corporeidade que também experimenta ( de maneira diferente da razão) e

\footnotetext{
118 MOLTMANN, Jürgen., O Espírito da Vida, p. 29.

119 lbid., p. 30.

120 Ibid., p. 31.

121 lbid., p. 32
} 
expressa diferentemente as experiências vividas. Essas experiências possuem dimensões diversas, aqui a luz do pensamento de Moltmann vamos analisar três dimensões: experiências de situações limites, que chamaremos de dimensão pessoal; experiências coletivas ou comunitárias,dimensão relacional e experiências de gerações que chamaremos de dimensão histórica.

\subsection{2 \\ Experiências de situações - limites (dimensão pessoal)}

Moltmann nos lembra que existem situações limites onde a experiência tem sua própria expressão em nós. Ele fala das experiências elementares da vida: de amor e de morte. Experiências onde somos atingidos por percepções de natureza sensível com tamanha força que não nos permitem controlá-la e nem racionalizá-las com tanta facilidade. ${ }^{122}$

Elas nos acompanham e passamos a vida toda tentando decifrá-las, reprimilas ou elaborá-las, interpretá-las, pois elas sempre estão ali, como uma nebulosa, dentro e fora de nós. Fora, ao nosso redor, rente a nossa pele, às vezes elas nos tocam, outras nós as tocamos; dentro, entrando pelas nossas narinas. Basta um toque ou suspiro mais profundo e elas nos invadem novamente e nos fazem sentir exatamente os mesmos sentimentos e sensações que tivemos em seu momento temporal. Para elas não há passado nem futuro, apenas um acontecer. O próprio Moltmann testemunha essa realidade: ${ }^{123}$

'O horror de antigas experiências de morte invadem-me ainda os membros, como se diz, mesmo quando delas não tenho consciência, e quando a minha atividade da razão' estabeleceu-Ihes uma data de 47 anos atrás, na tempestade de fogo sobre Hamburgo em 1943. Mas elas estão presentes a cada momento. Posso recolocarme nelas e voltar a sentir as mesmas angústias de então. Desde aquele dia minha vida foi por elas colocada sob estas perguntas cruciantes: 'Onde está Deus?' e 'Por que eu também não morri?'124

Moltmann é muito corajoso ao afirmar que em experiências como estas não existe "um tempo que cura as feridas", como também não existe uma graça do esquecimento. Não se pode dizer que tal experiência tenha sido feita, como se

\footnotetext{
122 lbid.

123 A guerra e o pós-guerra foram, segundo o próprio Moltmann, oportunidades de se colocar seriamente a questão sobre Deus, que até então não o tocava. Nos campos de prisioneiros, ele experimentou o colapso de suas certezas, e a partir desse colapso encontrou uma nova esperança na fé cristã. Para Moltmann, a pergunta era: "Como não falar de Deus depois de Auschwitz? Naquele contexto, ele conheceu Jesus abandonado e clamando por Deus, e percebeu que seria entendido por ele. Um Deus que conhece o sofrimento pode entender quem sofre".

${ }^{124}$ MOLTMANN, Jürgen., O Espírito da Vida, p. 32.
} 
esta estivesse pronta ou acabada. ${ }^{125}$ Nós experimentamos, revivemos, sofremos uma vez, e de novo e de novo, e elas não são lembranças, são sempre um acontecimento do agora em nossas vidas e estão sempre nos cobrando uma resposta. ${ }^{126}$ São para sempre não porque estão em nós, mas porque resultaram no que nós somos hoje e ainda poderão nos transformar amanhã.

Também no amor e na felicidade não podemos dizer que "fizemos" uma experiência, primeiro não fomos nós que fizemos, esta experiência é que nos encontrou e fez algo em nós, segundo porque ela nunca se esgota, está sempre a nos transformar e também suscitando em nós uma nova resposta. ${ }^{127}$ Elas também não estão sujeitas ao tempo, são essa nebulosa dentro e fora do sujeito da experiência, tocam não só a corporeidade mas também o mundo em volta do sujeito. Uma aliança pode trazer de volta o toque da pessoa amada, assim como a pronúncia de um apelido de infância pode trazer de volta a presença de um pai carinhoso.

São experiências que não estão no passado, pois a realidade de ser amado/a é algo que nos pervade por toda vida e que nos ajuda a reinventar a cada dia uma versão melhor de nós mesmos.

Nós não "fazemos" experiências de vida e morte, nós vivemos nelas, nós não as superamos, nãos as deixamos no passado, nem sequer as compreendemos. ${ }^{128}$ Dizer que as fizemos, que as superamos, ou que as compreendemos é uma tentativa de controlá-las, de dominá-las, mas a dominação não é possível nas experiências elementares de dor e felicidade, pois são experiências de Deus, por mais terríveis que estas sejam. Nelas tocamos o núcleo de nossa existência, não encontramos para elas uma expressão. Nós nos tornamos expressão delas.

É a dimensão de perigo e travessia, não sou eu quem faço a experiência, ela é que faz algo em mim. Quando vivemos estas experiências o centro da ação não está em nós, mas sim naquilo que nos acontece, em sua origem. Podemos perceber com nossa razão e nossos sentidos um acontecer externo e observar em nós mesmos as alterações que este acontecimento realiza. Alterações que podem se dar até mesmo na estrutura anterior do sujeito, podem reforçá-la ou destruí-la, estamos sempre sujeitos à modificações pelas quais não esperamos.

\footnotetext{
125 Ibid.

126 Eu mesma, re-experiencio por vezes os mesmos sentimentos, angustias e sensações da experiência de violência que vivi na infância, sou capaz de sentir o cheiro de queimado da comida deixada no fogo no momento em que gritos e socos invadiam a cozinha da casa de minha avó. 127 lbid., p. 33. 
No entanto, não existem experiências elementares de vida se não nos abrimos sem nossa abertura, sem receptividade e prontidão, sem o risco da automodificação. ${ }^{129}$ Tais experiências têm a capacidade de nos mostrar nossa paradoxal realidade de seres infinitos e finitos.

De um lado nos fazem nascer, morrer e ressuscitar várias vezes, nos dão a possibilidade de nos tornarmos expressão viva de um acontecer, seja de morte ou vida, onde de alguma forma Deus se revelou e nos mostrou nossa dimensão escatológica: somos para além do que entendemos ser.

Por outro lado nos colocam no limite da nossa humanidade, por elas compreendemos que não somos senhores nem do tempo e nem do futuro. Certezas, seguranças, domínio, tudo cai por terra, passamos a ver o que é real sem dogmatismos, sem ilusões. ${ }^{130}$

A verdadeira experiência é aquela na qual o homem se torna consciente da sua finitude. Nela, o poder fazer e a autoconsciência de uma razão planificadora encontra seu limite. Mostra-se a como pura ficção a idéia que se pode dar marcha ré a tudo, de que há sempre tempo para tudo, e de que, de um modo ou de outro tudo retorna. Quem está e atua na história faz constamente a experiência de que nada retorna. ${ }^{131}$

As experiências de situações-limites são então necessárias para o nosso processo de humanização, por elas nos compreendemos sendo finitos, limitados, mas possuindo em nós uma semente de eternidade nos é concedida pelo Espírito de Deus que inhabita os nossos corações.

\subsection{3 \\ Experiências que criam comunhão (dimensão relacional)}

Já afirmamos antes que toda experiência anseia por uma expressão, nós expressamos ou somos expressão de nossas experiências e com isto nós comunicamos nossa automodificação. No nível das relações nossa autoexperiência é reforçada pela experiência do outro, nós experimentamos o amor e sentimos como somos experienciados por alguém que nos ama. ${ }^{132}$

É na teia das relações sóciais que nossa auto-experiência se afirma ou se dissipa, nos vemos no olhar do outro, participamos de uma porção de nós mesmos

\footnotetext{
${ }^{129}$ MOLTMANN, Jürgen., O Espírito da Vida, p. 34.

130 GADAMER, Hans Georg. Verdade e método, p. 527.

131 lbid.

132 MOLTMANN, Jürgen., O Espírito da Vida, p. 34
} 
que vive na experiência do outro, ainda que de maneira limitada pois certas experiências individuais são incomunicáveis.

Algumas experiências porém, são capazes de criar comunhão, experiências que moldam uma comunidade, que criam laços entre pessoas que estruturalmente podem ser muito diferentes. Estas experiências geralmente são transmitidas em forma de narrativa e são contadas em diversas situações, às vezes narradas numa maneira nova, e são elas que dão consistência a uma comunidade criando a possibilidade de uma experiência mútua ou uma experiência pessoal. ${ }^{133}$

Muitas vezes até mesmo experiências de situações limite podem se tornar experiências de comunhão. ${ }^{134}$ Surgem espaços comuns , experiências mútuas que vão não só alimentando a comunidade como também vão possibilitando novas experiências. Solidariedade, amizade, confiança, identificação vão sendo tecidas a cada narrativa.

\subsection{4 \\ Experiências que perpassam gerações (dimensão histórica)}

Essas narrativas podem perpassar o tempo e alcançar gerações, nelas as experiências são sempre atualizadas e a nebulosa passa a existir não só para o sujeito da experiência , mas também para o coletivo. O palco do acontecer agora é o grupo, a comunidade, uma etnia ou até mesmo uma nação. A experiência que por si só é atemporal, é tornada presente e sua origem colocada em comum, o que faz com que os membros da comunidade possam suas experiências próprias a partir da mesma. ${ }^{135}$

Toda geração de Israel de sente como se ela própria tivesse saído do Egito, é o que ensina o Deuteronômio:

Quando tiveres entrado na terra que o Senhor teu Deus te dá por herança e dela tomares posse, estabelecendo-te aí, tomarás os primeiros frutos de tudo o que a terra produz, colhidos da terra que o Senhor teu Deus te dá e, pondo-os numa cesta, irás ao lugar que o Senhor teu Deus tiver escolhido para nele fazer morar seu nome. Irás apresentar-te ao sacerdote em exercício e Ihe dirás: 'Reconheço hoje diante do Senhor meu Deus que entrei na terra que o Senhor jurou a nossos pais

\footnotetext{
133 lbid., p. 36.

134 Um exemplo dessa transformação é o processo vivido por mulheres vítimas de violência na Pastoral da Mulher e nas CEB'S. Nos encontros da Pastoral da Mulher Marginalizada, nos Grupos de Círculos Bíblicos, as mulheres vão se auto-gerando, redescobrindo a vida que antes, sufocada pela dor parecia não mais poder ser mudada.

${ }^{135}$ MOLTMANN, Jürgen., O Espírito da Vida, p. 36.
} 
que nos daría'. O sacerdócio receberá de tua mão a cesta, e a colocará diante do altar do Senhor teu Deus. Então declararás diante do Senhor teu Deus: 'Meu pai era um arameu errante, que desceu ao Egito com um punhado de gente e ali viveu como estrangeiro. Mas ele tornou-se um povo grande, forte e numeroso. Então os egípcios nos maltrataram e oprimiram, impondo-nos uma dura escravidão. Clamamos então ao Senhor, Deus de nossos pais, e o Senhor ouviu nossa voz e viu nossa opressão, nossa fadiga e nossa angústia; o Senhor nos tirou do Egito com mão forte e braço estendido, no meio de grande pavor, com sinais e prodígios, e nos introduziu neste lugar, dando-nos esta terra, terra onde corre leite e mel. Agora, pois, trago os primeiros frutos da terra que tu me deste, Senhor. (Dt 26,1-11)

Nota-se como a narrativa israelita é atualizada, para que as gerações possam reviver a experiência do grupo de Moisés: "os egípcios nos maltrataram", "ouviu nossa voz", "viu nossa opressão", "nossa fadiga e nossa angústia"; através da narrativa, a experiência comum cria uma comunhão entre gerações de modo que todo aquele/a que adere à comunidade se insere no passado, presente e futuro da mesma.

\subsection{5 \\ O Espírito de Deus nas experiências de vida}

Nossa reflexão a partir pensamento de Moltmann nos leva então a afirmar que toda verdadeira experiência de vida é experiência de Deus. Ou seja, toda experiência cotidiana resguarda um fundo transcendente; é como se "vida" fosse então o outro nome de "Deus", assim, celebrar a vida é celebrar a Deus. É claro que não fazemos a experiência do "todo" de Deus porque Ele é espírito absolutamente transcendente em relação ao mundo, mas o experimentamos na sua transcendência imanente. ${ }^{136} \mathrm{Ou}$ seja, na sua presença em nós, e no mundo criado. ${ }^{137}$

"O Espírito de Deus enche a terra, a tudo dá consistência e tem conhecimento de tudo que se diz" (Sb 1,7). Deus está em tudo e em todos,vivificando e transformando o mundo.

A imanência de Deus em todas as coisas vem sendo objeto da reflexão teológica no tempo presente, e cunhou-se a expressão "panenteísmo" para dar conta dessa presença de Deus no cosmos e do cosmos em Deus. Distintamente

\footnotetext{
${ }^{136} \mathrm{O}$ conceito de transcendência imanente é proposto por Moltmann como uma alternativa a estreita referência à autoconsciência moderna. Deus é absoluto, o mundo não é Deus, mas Deus está no mundo, compenetrando-o e vivificando-o por dentro. "Só o Espírito pode ser mais íntimo que o meu íntimo..., só o Espírito pode ser a tal ponto imanente ao homem e ao mundo, permanecendo inviolável e imutável em sua transcendência absoluta".

137 Ibid., p. 43-44
} 
do "panteísmo", que não resguarda a diferença entre Deus e o mundo, a nova perspectiva ressalta sua mútua interpenetração, ${ }^{138}$

Tudo não é Deus. Mas Deus está em tudo e tudo está em Deus, por causa da criação, pela qual Deus deixa sua marca registrada e garante sua presença permanente na criatura (Providência). A criatura sempre depende de Deus e o carrega dentro de si. Deus e mundo são diferentes. Um não é o outro. Mas não estão separados ou fechados. Estão abertos um ao outro. Encontram-se mutuamente implicados. Se são diferentes é para poderem se comunicar e estarem unidos pela comunhão e mútua presença. ${ }^{139}$

O teólogo Faustino Teixeira, lembra que esta abordagem teológica, a capacidade de perceber a presença do Mistério em todas as coisas é muito comum entre os místicos. Mestre Eckhart fala do Deus que "resplandece em todas as coisas" e Teilhard de Chardin, do Deus tangível que, como uma atmosfera, envolve o ser humano por todos os lados. O monge e poeta nicaraguense, Ernesto Cardenal, desvenda na natureza o amor "perceptível e materializado de Deus". Ela guarda em si o "esplendor de sua beleza". Na tradição sufi, o místico lbn 'Arabi desvenda nas diversas formas que o mundo encerra a presença da "linguagem de Deus". ${ }^{140}$

A possibilidade de reconhecer Deus em todas as coisas e todas as coisas em Deus fundamenta-se teologicamente na compreensão do Espírito de Deus como a força da criação e como a fonte de vida. A experiência do Espírito de Deus, é sempre a consciência do "espírito da comunidade", da "divindade comunitária, que une Eu,Tu e Nós. ${ }^{141}$ A comunhão que faz com que eu reconheça na experiência do outro a divina presença, que gera laços que duram gerações, que suscita compromisso com o outro e com o mundo criado.

\footnotetext{
138 A expressão grega "panenteísmo" significa a conjunção de pan (tudo), en (em), e theós (Deus). Ou seja: tudo em Deus. Algo distinto de "panteísmo": pan (tudo) e theós (Deus). TEIXEIRA, Faustino., "O irrevogável desafio do pluralismo religioso", p. 28.

139 BOFF, Leonardo., Ecologia, p. 236.

140 TEIXEIRA, Faustino., "O irrevogável desafio do pluralismo religioso", p. 29.

141 MOLTMANN, Jürgen., O Espírito da Vida, p. 44-45.
} 


\section{3 \\ Experiência do Espírito na Bíblia}

\subsection{1 \\ No Antigo Testamento}

O Povo de Israel sempre ligou suas experiências de Deus a pessoas históricas ou acontecimentos históricos. A presença de Deus para seu povo não parte de uma abstração teológica, mas do testemunho das experiências de vida dos seus patriarcas ou do próprio povo. É o "Deus de Abraão", o "Deus de Isaac", o "Deus de Jacó", o "Deus do Egito", o "Deus da Aliança", o "Deus da Terra Prometida". A experiência do Espírito é narrada por Israel a partir compreensão de sua própria história. O Espírito de Deus é Deus é a energia criadora (Gn), é a força libertadora (Ex), é a Sabedoria que rege o justo (Sb), é o resgatador, o advogado dos mais fracos ( $\mathrm{Nm}$ ), é Deus mesmo, em cada passo, a cada caminho e junto ao povo na caminhada.

\subsection{2 O termo Ruah}

Espírito na nossa língua é do gênero masculino, e identificado como um ser pessoal, espiritual, alma, algo que não possui corpo e que está acima de tudo que é sensível e terreno. Mas em hebraico é Ruah, palavra feminina e que ,como nos lembra o biblista Carlos Mesters ${ }^{142}$ tem dois significados básicos: um ligado ao fenômeno natural do vento, ar brisa , tempestade; outro ligado ao fenômeno da respiração, fôlego, hálito, alento. Para este biblista a Ruah , propriamente dita não se identifica com estes fenômenos, mas indica algo que se encontra em todos eles: o estar em movimento. ${ }^{143}$

A Ruah é uma energia em movimento, mas um movimento que tem uma direção definida, que pode ser percebido no próprio movimento que ela produz.

142 Carlos Mesters é frade Carmelita, doutor em Teologia Bíblica. É natural da Holanda e ligado à caminhada das Comunidades Eclesiais de Base, ajudou a criar o CEBI (Centro de Estudos Bíblicos). Escreveu, entre outros, Esperança de um povo que luta (São Paulo: Paulus, 1983), Círculos bíblicos (São Paulo: Paulus, 2001), Paulo apóstolo: um trabalhador que anuncia o evangelho (São Paulo: Paulus, 2002), Bíblia: livro feito em mutirão (São Paulo: Paulus, 2002), e Por trás das palavras (Petrópolis: Vozes, 2003).

143 MESTERS, Carlos., "Descobrir e discernir o rumo do Espírito", p. 32. 
Uma energia que se movimenta, que põe outras coisas em movimento e que acima de tudo é livre. Ninguém controla a Ruah, ela é vento que sopra onde quer $\left(\right.$ Ecl 8,8). ${ }^{144}$

Poderíamos dizer que, mais do que um simples simbolismo, talvez a experiência cotidiana do povo diante da força da tempestade, da liberdade do vento, possa ter ajudado a identificar a presença de Deus em suas vidas. A Ruah está presente em sua história e na história do mundo, ela é o vento que agita as águas do caos no momento da criação $\left(G_{n} 1,2\right)$, ela é força que abre o mar Vermelho (Ex 14,21), ela é a força exterminadora e a graça vivificante (Ez 13,13s; $36,26 s)$.

Mas o significado mais existencial da Ruah, talvez seja aquele que a liga à respiração, ao fôlego, ao alento. Essa definição indica o mais íntimo do ser humano, a essência da vida é inspirar e expirar o ar, a Ruah é então a força vital do ser humano. É a energia ou movimento que a pessoa sente dentro de si, como resistência e que só entregamos na hora da morte $(\mathrm{SI} 3,6){ }^{145}$

Experiência de situações-limite, nos ajudam a compreender esta definição mais existencialmente, pois como dissemos, nos mostram nossa pardoxal realidade de seres finitos, movidos por uma força infinita. Compreensão que o povo do AT já possuía. Diante do poder e a força da Ruah, o ser humano é frágil, é barro (Gn 2,7), é o sopro de Deus que o torna vivente. E o acontecer (o sopro) é maior que o "espaço" onde ele acontece: "A largura da mão: eis a medida de meus dias, diante de vós minha vida é como um nada; todo homem não é mais que um sopro"(SI 38,6). A força vital criadora é maior que a força criada : "Se retiras a sua Ruah, morrem e voltam ao pó; se envias a tua Ruah, são recriados e renovas a face da terra" (SI 104,29s).

Mas a Ruah também é fôlego, e o fôlego é a ação primeira de todo ser humano ante qualquer sentimento, sensação ou percepção. É movimento que inicia um sentimento ou pausa um momento. É o encontro silencioso com o que há de mais profundo em nós mesmos, como se buscássemos repentinamente algo que, naquele instante, racionalmente não sabemos o que é, mas sentimos estar lá e por isso buscamos.

Nós usamos a expressão "tomar fôlego", quando fazemos uma pausa de um trabalho, uma empreitada, um projeto. É o sopro que faz realizar uma obra, se esta é, de certo modo, a obra de Deus (Ex 31,3s). ${ }^{146}$ Este sopro conduz o povo

\footnotetext{
144 Ibid., p. 33.

145 lbid.

146 CONGAR, Yves., Creio no Espírito Santo 1, p. 19.
} 
de Deus, o prepara para encabeçar suas guerras, unge seus reis e profetas, como veremos mais adiante.

Da experiência do povo de Deus no AT, podemos então entender a Ruah como:

- Acontecer da presença atuante de Deus que penetra o ser humano no mais íntimo de sua existência, a ponto deste não poder fugir de seu olhar. Nem as trevas, nem o abismo, nem a morte, nada pode ocultar o ser humano d'Aquele que o sonda e o conhece; (SI 139);

- Força criadora de Deus comunicada a toda criatura, transcendente, porém imanente como força de vida de tudo o que foi criado. De tal forma que Deus está em todas as coisas e todas as coisas estão em Deus, mas sem se equipararem e sem se confundir: o criador é criador e criatura é criatura;

- É movimento de liberdade, ninguém pode controlar o Espírito, ninguém é seu dono ou controla sua direção. Nós não possuímos o Espírito, ele é quem nos possui.

O Espírito ESTÁ para que o homem SEJA. Ele é a potência criadora que possibilita o ser humano recriar o mundo e a si mesmo. Ele estava no início pois pela sua energia e movimento tudo foi criado, ele é o sopro de Deus que antecede e acompanha toda criação. Ele é o fôlego que o ser humano necessita para ter coragem, resistência e comunhão, é a força vital que ultrapassa nosso frágil invólucro de barro à espera do nosso definitivo despertar.

\subsection{3}

\section{Êxodo - O Espírito que faz ser livre}

A narrativa do Êxodo marca a experiência fundante do povo de Israel, na experiência coletiva mais marcante de sua história a presença do Espírito de Deus já se faz presente. A palavra êxodo significa saída. No livro do Êxodo este nome está intimamente ligado à libertação da opressão do Egito mediante a ação do único Deus, que ouve o clamor do povo oprimido e o liberta. É a partir da experiência que se faz ao sair da opressão para se viver num espaço amplo de liberdade, que nasce um povo, o povo de Deus.

Nesta época o Faraó Ramsés II resolve construir uma cidade e armazéns na região de Gessen. Este Faraó era intransigente e passou a exigir trabalhos cada vez mais forçados de seus escravos/as. Esta situação de extrema opressão e dominação colabora para que estes/as tomem consciência de sua condição e 
contribui para despertar neles/as o desejo de liberdade que se expressa em oração (Ex 1,1-2,25). Deus responde à prece destes homens e mulheres chamando Moisés para liderá-los na concretização desta libertação. (Ex 3,112). ${ }^{147}$

É por isso que se afirma que a "experiência fundante de Israel é o ato da libertação." Este ato "não só funda um povo, mas também uma fé no Deus que liberta o oprimido, dando-lhe a chance de abrir caminhos novos dentro da história". ${ }^{148}$

\begin{abstract}
lahweh disse: 'Eu vi a miséria do meu povo que está no Egito. Ouvi seu grito por causa dos seus opressores; pois eu conheço as suas angústias. Por isso desci a fim de libertá-lo da mão dos egípcios, e para fazê-lo subir desta terra para uma terra boa e vasta, terra que mana leite e mel, o lugar dos cananeus, dos heteus, dos amorreus, dos ferezeus, dos heveus e dos jebuseus. Agora, o grito dos israelitas chegou até mim, e também vejo a opressão com que os egípcios os estão oprimindo. Vai, pois, e eu te enviarei a Faraó, para fazer sair do Egito o meu povo, os israelitas. (Ex 3,7-10)
\end{abstract}

Transcendente, na sarça que arde sem se consumir, no lugar que é sagrado para o qual Moisés tira a sandália (Ex 3,2-5), o Deus que se apresenta está (imanente) ao lado do seu povo. O Espírito de Deus está com eles na experiência do cativeiro, e por isso intervém, desce para libertar esse povo e fazê-lo subir para uma terra onde há liberdade e vida. Este acontecimento fundante, onde Deus intervém na história, como o Deus que cria vida e liberdade, não se trata de uma simples mudança de lugar geográfico (de uma terra para outra, isto é, sair do Egito para chegar a Canaã).

Êxodo é na realidade a conquista do próprio espaço para, "na liberdade, construir uma sociedade nova e sempre aberta à criação de espaços cada vez mais significativos para o povo expandir a sua experiência de vida". ${ }^{149}$ Portanto, a saída da terra da opressão tem um objetivo que é o de conquistar uma terra onde o povo possa viver a liberdade e encontrar a vida. Este binômio "liberdade e vida" é uma das características da Ruah destacada por Jürgen Moltmann quando baseando-se na afirmação de Helen Schüngels-Straumann nos diz que esta Ruah é espaço amplo onde acontece vida e liberdade. ${ }^{150}$

\footnotetext{
147 MESTERS, Carlos., Deus onde estás?, p. 45.

148 STORNIOLO, I.; BALANCIN, E. M. Como ler o livro do Êxodo, p. 14.

149 Ibid., p. 15.

150 MOLTMANN, Jürgen., O Espírito da Vida, p. 51.
} 


\subsection{4 Juízes e Juízas - 0 Espírito que faz a Justiça}

No período tribal, o sopro de Deus capacitava os juízes para agirem em situações especiais em momentos em que a vida e a liberdade conquistada estavam ameaçadas. Agia sobre homens e mulheres que eram transformados, ao olhar do povo, em líderes e guerreiros carismáticos que atuaram durante os 150 anos, que separam a conquista de Josué e a instituição da monarquia. ${ }^{151}$

As pessoas possuídas e dirigidas pelo Espírito agem em lugar de Deus e em seu nome, guiando seu povo para a liberdade. São dons carismáticos, isto é, espontâneos e por prazo limitado, de indivíduos em benefício de todo povo, e neste sentido são também dons corporativos do povo inteiro. ${ }^{152}$

Os Juízes e Juízas eram personagens corporativas, ${ }^{153}$ isto é, eram entendidos como uma pessoa que representava Deus no meio do povo e representava o povo diante de Deus. Conseqüentemente ao receberem os carismas da Ruah, estariam recebendo dons corporativos do povo da Aliança, o que significa dizer que todo o povo recebia estes dons através da figura do Juiz/a. É importante que se destaque o papel da mulher como líder do povo, isto é, como Juíza neste período da história que ficou na memória do povo como um tempo ideal.

O sopro de Deus - a Ruah, estava sobre estes homens e mulheres, Otoniel (Jz 3,10), Gedeão (Jz 6,34), Sansão (Jz 11,29); Débora sobre a sobra da palmeira não só julgava como profetizava $(\mathrm{Jz} 4,4)$. O dom carismático produz vidência, sabedoria, profecia e liderança. ${ }^{154}$ No entanto o sujeito real nestas histórias era sempre a Ruah de Yahweh, nas experiências dos heróis e heroínas estava a presença de Deus, que agia até mesmo nos atos de astúcia destes (Jz 4,17-22).

\footnotetext{
151 CONGAR, Yves., Creio no Espírito Santo 1, p. 19-21

152 MOLTMANN, Jürgen., O Espírito que dá vida, p. 52.

153 É preciso lembrar que a noção de um indivíduo representando um grupo e reciprocamente um grupo social representado por um indivíduo era muito comum para este povo. TEPEDINO, Ana Maria., Encontro com a Igreja de Jesus Cristo (Eclesiologia), p. 40.

${ }^{154}$ MOLTMANN, Jürgen., O Espírito que dá vida, p. 52.
} 


\subsection{5 \\ O Espírito que falou pelos Profetas}

A força do Espírito que irrompia nos juízes/as capacitando-os para a liderança e para agir nos momentos de necessidade do povo, depois da entrada da monarquia não é mais transmitida de maneira espontânea, mas através da unção (1Sm 16,13) e da imposição das mãos (Dt 34,9). O que era dom passa a ser "direito" dos reis, o que acaba gerando a tentação de controlar sua ação em favor dos interesses da monarquia. ${ }^{155} \mathrm{E}$ como já sabemos, a Ruah, vento, força, sopro, não pode ser controlada, sem se deixar levar pelo seu movimento falta justiça, falta liberdade, falta vida. Surgem então os profetas, escolhidos desde o ventre materno para dar voz ao Espírito de Deus (Jr 1,5). ${ }^{156}$

No entanto, podemos dizer que a rigor somente os profetas pré exílicos se baseiam na inspiração da Ruah de Yahweh (Nm 11,17ss; 24,2, 2Sm 23,2; $1 \mathrm{Cr}$ 12,18; Is 61,1; Mq 3,8; Ez 2,2; 3,12.14.24; 8,3; 11,1.5.24; 37,1; 43,5; Ne 9,30; Zc $7,12)$. Os profetas mais tardios, os chamados clássicos, como Amós, Oséias, Miquéias, Isaias e Jeremias, anunciavam o dabar de Yahweh (palavra de Deus). ${ }^{157}$ O profeta é o homem do Espírito que tinha a função de mediar o dabar de Yahweh junto ao povo, isto é, tinha a função de comunicar ao povo esta Palavra que liberta e possibilita a vivência da justiça.

Isidoro Mazzarolo define o profeta como:

Um vidente, um embaixador de Deus, um arauto da justiça e, por conseqüência, perseguido, caluniado e difamado (Mt 5, 11-12). O Profeta é a memória da Libertação do Egito e a consciência da cidadania e direitos sociais em nome da fé. O Profeta não tem outro parâmetro para a crítica social, política ou religiosa senão a fé em um Deus que liberta (Ex 20,1) e que não admite a escravidão, em qualquer de seus desdobramentos. O Profeta é a consciência e o discernimento da dignidade do ser humano e sua dupla relação: com Deus e o outro. ${ }^{158}$

Para José Luís Sicre o profeta:

É o homem da palavra [...] No drama dos livros proféticos, o primeiro personagem é a palavra [...] [Ela] apodera-se do profeta com tal força, que a partir desse instante se deve definir toda a existência dele em termos de palavra [...], o profeta nunca

\footnotetext{
${ }^{155}$ MESTERS, Carlos., "Descobrir e discernir o rumo do Espírito. Uma reflexão a partir da Bíblia", p. 34.

156 "Pelo menos a partir do símbolo batismal de São Cirilo de Jerusalém (por volta de 348), mas já em Justino e Irineu, o Espírito Santo é caracterizado como aquele que falou pelos profetas". Segundo Yves Congar, essa, era uma forma de afirmar, contra a gnose de Marcião, que o Espírito que fez Jesus ser concebido e que anima o Evangelho é o mesmo que agia na antiga Disposição. CONGAR, Yves., Creio no Espírito Santo 1, p. 22.

${ }^{157}$ MOLTMANN, Jürgen., O Espírito que dá vida, p. 53.

158 MAZZAROLO, Isidoro., O Clamor dos Profetas ao Deus da Justiça e Misericórdia, p. 13.
} 
pronuncia palavras próprias, mas a palavra que Deus põe na sua boca para que a transmita aos contemporâneos. ${ }^{159}$

Para nós é fundamental afirmação de que o profeta é o homem do Espírito, e também o homem que ouve a palavra de Deus e a comunica. Portanto, com base nestas declarações podemos ratificar a afirmação de Yves Congar, a saber, "Espírito e Palavra estão muito unidos especialmente nos eventos proféticos."160 Este vínculo entre Palavra e Espírito na atividade profética, é o que concede a este o estatuto de ser o guardião do projeto de Deus, que coincide com as aspirações do povo, sendo a missão verdadeira do profeta de lahweh a de revelar a bondade de Deus aos pequenos. ${ }^{161}$ Para isso, ele é escolhido por Deus. Ninguém escolhe ser profeta por si mesmo (1Sm 3). O momento deste chamado (vocação) supõe uma experiência de Deus, uma descoberta que marca a existência do profeta e onde ocorre algo de novo. ${ }^{162}$ É a força do Espírito convocando homens e mulheres para falar em seu nome. ${ }^{163}$

Voltando a colocação de Moltmann, sobre o fato de no profetismo tardio ser anunciado o dabar Yahweh e não a Ruah, o mesmo autor vai nos chamar a atenção para o fato de que, no pós- exílio, podermos encontrar em Ezequiel e no Deutero-Isaias um forte apelo à Ruah de Yahweh e a inspiração em visões e profecias embora estas não sejam acompanhados pelo transe atribuído ao Espírito de Deus nos tempos primitivos de Israel (1Sm10,5s; 19,20-24). ${ }^{164}$ Daremos maior atenção aqui aos textos de Isaias, que utiliza cinqüenta vezes o termo Ruah; e Ezequiel que utiliza o termo 46 vezes. ${ }^{165}$

No texto de Isaias encontramos tudo aquilo que é comum à experiência de Israel em relação a Ruah e sua força e vitalidade enquanto sopro de Deus (Is $3,31)$. Deus é quem comunica a vida, após o anúncio da queda da Samaria, o profeta opõe às suas flores murchas a coroa brilhante que será o Senhor, "o diadema e o adorno do resto de seu povo. Ele será o espírito de justiça para aquele que senta para julgar" (Is 28,5-6). No meio da desesperança , o profeta anuncia a libertação: 166

\footnotetext{
159 SICRE, José Luis., Profetismo em Israel, p. 101-102.

160 CONGAR, Yves., A Palavra e o Espírito, p. 26

161 VARONE, Francois., Esse Deus que dizem amar o sofrimento, p. 32.

162 SICRE, José Luis., Profetismo em Israel, p. 119.

163 Uma particularidade, para nós, importante do profeta de lahweh é a que nos traz Sicre quando nos afirma que "as mulheres podem fazer parte deste movimento, e até com grande prestígio, dado este muito importante se recordarmos que em Israel elas não têm acesso ao sacerdócio. " Este autor cita como exemplo de profetas mulheres: Maria, irmã de Aarão, que une profetismo e música (Ex 15,20); Débora (Jz 4,4) profetisa e juíza; Hulda (2Rs 22,14) .lbid., p. 81-82.

${ }^{164}$ MOLTMANN, Jügen., O Espírito que dá vida, p. 53

165 CONGAR, Yves., Creio do Espírito Santo 1, p. 23.

166 lbid.
} 
Um ramo sairá da cepa de Jessé, um rebento brotará de suas raízes. Sobre ele repousará o Espírito do Senhor: espírito de sabedoria e discernimento, espírito de conselho e valentia, espírito de conhecimento e de temor do Senhor [...] (Is 11,1-2).

O Messias receberá os dons necessários para reinar com justiça,reinar sob o poder do Espírito, e tal reinado fala ao coração do povo como aquilo que este mais almeja:

[...] até que seja derramado sobre nós o Espírito do alto. Então o desrto se transformará em vergel, e o vergel será tido como floresta. O direito habitará no deserto e a justiça morará no vergel. O fruto da justiça será a paz, e a obra da justiça consistirá na tranqüilidade e na segurança para sempre. Meu povo habitará em moradas de paz, em mansões seguras em lugares tranqüilos (Is 32, 15-18).

Segurança, paz, casa para morar, justiça e direito, o profeta fala de experiências de vida almejadas por qualquer ser humano, experiências pelas quais nos sentimos amados e protegidos. É uma vida renovada, renascida, dada pelo poder do Espírito de Deus. Uma vida que mesmo nos momentos em que se sente distante a "Presença" (destruição do templo, ruína de Jerusalém e a deportação para a Babilônia), ${ }^{167}$ encontra no Espírito a possibilidade de renascer, é o que profetiza Ezequiel nos belíssimos capítulos 36 e 37 :

Farei de vós uma aspersão de água pura e ficareis puros; eu vos purificarei de todas as vossas impurezas e de todos os vossos ídolos. Eu vos darei um coração novo e porei em vós um espírito novo; tirarei de vosso corpo um coração de pedra e vos darei um coração de carne. Infundirei em vós o meu sopro (espírito) [...] (Ez 36,2527).

[...] Filho do homem, estas ossadas podem reviver? Eu disse: 'Senhor Deus, tu o sabes!' Ele me disse: 'Pronuncia um oráculo sobre essas ossadas; dize-lhes: Ossadas ressequidas, escutai a palavra do Senhor. Assim fala o Senhor Deus a essas ossadas: Farei vir sobre vós um sopro para que vivais' [...]. Pronunciei o oráculo como havia recebido a ordem, o sopro entrou neles e eles reviveram; puseram-se de pé [...] (Ez 37,3-5.10).

Diante da invasão e do exílio, as profecias ajudaram o povo de Israel a ler estas experiências sob a luz da ação purificadora e santificadora do Espírito. Ele penetra seus corações e possibilita um novo começo, um novo Êxodo, uma nova Aliança, faz deles um novo povo. "Deus será através de seu sopro-Espírito santo, princípio de vida fiel e santa para Israel". ${ }^{168}$ Por volta de 350-400 a.C., o profeta Joel estenderá esse dom a todos os povos (Jl 3,1-2). E Pedro proclamará esse derramamento do Espírito no dia de Pentecostes. 


\subsection{6 \\ O Espírito de Deus e sua Shekiná}

O teólogo Jürgen Moltmann nos apresenta uma importante reflexão acerca da presença do Espírito de Deus no AT. Segundo Moltmann fala-se da Ruah de Yahweh de muitas maneiras e ligada a outros conceitos no AT, mas do ES só se vem a falar em época tardia ( $S I 51,13$; Is 63,10$)$ e de maneira restrita, já que na literatura rabínica primitiva , ES teria o significado de "espírito do santuário". ${ }^{169}$ Quando hoje falamos do ES , falamos de Deus mesmo e não apenas em um dos seus dons, o ES é o doador dos dons, ou seja é Deus quem se doa a si mesmo.

A reflexão teológica feita acerca da Ruah como evento da "presença de Deus" não pode ser ligada a conceituação israelita da palavra "Espírito Santo". O conceito hebreu que teologicamente mais se aproximaria desta concepção da "presença divina" seria o da shekiná, "a descida e inhabitação de Deus no espaço e no tempo, num determinado lugar e determinado tempo de criaturas terrenas e em sua história". 170

A idéia da shekiná, e lembramos que estamos falando da idéia e não do vocábulo, provém da linguagem cultual e na sua origem significa o "armar a tenda" e o "morar"171 de Deus junto ao seu povo na arca que era transportada e mais tarde, como se pode ver no texto de Isaías, afirma-se que ele habita no templo, no monte Sião, pois é aí que ele encontra seu repouso ${ }^{172}$. Depois da destruição de Jerusalém e o exílio de uma parte do povo para a Babilônia, onde Deus então estaria para ficar com seu povo?

Surge o pensamento de que Deus inabita em seu povo e que ele acompanha seu povo ao exílio através da shekiná. A shekiná está presente na comunidade dos orantes. Ela está nas sinagogas, no colégio dos juízes, no meio dos pobres, dos doentes etc. A shekiná compartilha das alegrias e dos sofrimentos de Israel. Ela é de maneira particular o divino 'companheiro do sofrimento de Israel'. Daí surge a esperança de que junto com o povo, a shekiná exilada haverá de retornar da terra estranha para Jerusalém. Quando Deus redime seu povo e o conduz para casa sua

\footnotetext{
169 MOLTMANN, Jürgen., O Espírito que dá vida, p. 54.

170 lbid.

171 "Quem queria "consultar lahweh" ia à Tenda, onde Moisés servia de intermediário junto a Deus, Ex 33.7. A tradição sacerdotal manteve o mesmo nome, com o mesmo sentido: a Tenda da Reunião é o lugar do 'encontro' com Moisés e o povo de Israel (Ex 29.42-43; 30.36). Mas essa tradição prefere chamá-la a 'Habitação', miskan, um termo que parece ter designado primeiramente a habitação temporária do nômade, (cf. o antiqüíssimo texto de $\mathrm{Nm} 24.5$ e o verbo correspondente em Jz 8.11, cf. também 2 Sm 7.6, logo, um sinônimo para 'tenda'). Os relatos sacerdotais escolheram essa palavra arcaica para exprimir o modo de habitação terrena do Deus que reside no céu. Eles preparam a doutrina judaica da Shekinah e João também lembra que: 'O Verbo...armou uma tenda entre nós' (Jo 1.14)”. DE VAUX, R. Instituições de Israel no Antigo Testamento, p. 333.

172 MOLTMANN, Jürgen., Op. cit., p. 56.
} 
shekiná peregrinante será redimida de suas errantes peregrinações e retornará para casa. ${ }^{173}$

A shekiná é então a presença do próprio Deus e uma propriedade de Deus, não é sua onipresença, mas sim uma presença especial querida e prometida a seu povo. Ela é presença temporal de Deus em determinado lugar. "Quando dois se sentam juntos para estudar a Torah, a shekiná está no meio deles". ${ }^{174} \mathrm{O}$ coração aberto à presença deste Deus, é a condição de possibilidade para que se faça a experiência da sua presença. A comunidade de Mateus viverá esta experiência na pessoa de Jesus: "Quando dois ou três estiverem reunidos em meu nome, eu estarei no meio deles" (Mt 18,20).

Essa presença divina do Deus que faz morada no meio do povo, é experimentada sobretudo nos momentos de sofrimento. Deus inhabita o coração do povo e nele não só conhece mais divide o seu sofrimento. O exílio de Israel, é o exílio de Deus, pois todo aquele que agride a Israel, agride a honra e o nome de Deus: "Em todas as suas angústias ele se angustiou" (Is 63,8s). "Estarei com ele na angústia" (SI 91,5). ${ }^{175}$ Mesmo caminhando pelo "no vale sombrio" ,no vale da morte, o povo sente a companhia da Shekiná, pois sua história fez conhecer um Deus com-passivo, ${ }^{176}$ que sofre junto, cuja experiência de amor vai acompanhar este povo de geração em geração até chegar Aquele que será o próprio amor "morando" no meio de nós.

\section{4 \\ Experiências do Espírito no Novo Testamento}

\subsection{1}

\section{A experiência do Espírito em Jesus}

A comunicação a todos os seres humanos de que as promessas de salvação de Deus, se cumprem em Jesus de Nazaré, ou seja, o Evangelho, começa com o chamado de João Batista à conversão e o batismo de Jesus (Mc 1,1s). Ao ser batizado, por João, Jesus é designado como aquele que por cuja palavra,

\footnotetext{
173 lbid.

174 SCHOLEM, G., Von der mystischen Gestalt der Gottheit. Apud MOLTMANN, Jürgen., O Espírito que dá vida, p. 56.

175 MOLTMANN, Jürgen., O Espírito que dá vida, p. 57.

176 lbid., p. 58.
} 
sacrifício e ação o Espírito entra na história como dom messiânico. ${ }^{177}$ É o mesmo Espírito que armou sua tenda no meio do povo e por ele que Maria concebeu Jesus, como afirma Lucas no início de sua "boa notícia" (Lc 1,35$)$. Jesus é Filho de Deus e habitado pelo ES desde o seio de Maria, no entanto seu batismo inaugura um novo capítulo em sua vida, nem Lucas ou Mateus, evangelhos que narram seu nascimento pelo poder do ES, falam de Jesus agindo na força do ES antes de seu batismo. ${ }^{178}$ No batismo está o início da sua missão, há uma comunicação que o declara Messias, aquele sobre quem repousa o Espírito, que agirá pelo Espírito, aquele que glorificado e feito Senhor nos dará plenamente este mesmo Espírito. ${ }^{179}$

Há uma unanimidade entre os quatro evangelhos ao testemunhar que Jesus foi batizado no Jordão, mesmo havendo algumas diferenças: para João $(1,32-34)$, Jesus já tem o Espírito e a teofania do Jordão é um atestado para João Batista; Lucas acrescenta que o batismo se deu em meio a multidão $(3,23)$ e que Jesus estava rezando, e que ao ser batizado o céu se abriu e desceu sobre ele (João diz permanece), sob a forma de uma pomba. ${ }^{180}$

Yves Congar nos lembra que a pomba não era símbolo do Espírito no Antigo Testamento e nem entre os rabinos. O dom do Espírito aos profetas era representado por um mensageiro alado celeste. Lembremos que Maria também recebe um mensageiro. A pomba então é uma mensageira que leva as palavras celestes. No entanto, a pomba era símbolo de Isarel, pode ser compreendida no batismo como a presença simbólica deste povo e com o movimento de penitência (movimento de João) com o qual Jesus quis se solidarizar. Além do mais os títulos de "Filho de Deus" e "Servo" eram aplicados a todo povo de Deus. ${ }^{181}$ Mais uma vez a experiência de Deus vivida pelo povo, é paradigma para sua compreensão da caminhada e da revelação deste mesmo Deus em sua história.

Assim como acontece no anúncio a Maria (Lc 1,35), a Palavra e o Espírito estão juntas e têm como destinatários a multidão (Mateus e Lucas) e a Jesus (segundo Marcos). Já no QE. João Batista dá testemunho de ter visto o Espírito em forma de pomba, permanecer sobre Jesus, mas não fala nada de palavra celeste. Esta palavra que nos demais evangelhos não é um chamado como para os profetas e para Paulo, mas "uma declaração que ressoa na consciência de

\footnotetext{
177 CONGAR, Yves., Creio no Espírito Santo 1, p. 32

178 Ibid.

179 lbid., p. 33.

180 lbid.

181 lbid., p. 34.
} 
Jesus, é a confirmação de uma condição que qualifica Jesus naquilo que ele é". ${ }^{182}$ Esse seria o momento que inaugura a vocação de Jesus, para o QE, ele toma plena consciência de ser aquele que "o Pai consagrou e enviou ao mundo" (Jo 10,36).

A teologia trinitária que se desenvolveu ao longo dos séculos vai afirmar que, naquele momento a natureza humana de Jesus foi inundada, plenificada, totalmente pelo ES, a fim de que Jesus iniciasse a sua missão messiânica na plenitude da força do Espírito. De fato, Lucas é muito explícito ao se referir ao início da missão de Jesus. "Cheio do Espírito Santo", voltou Jesus do Jordão e foi levado pelo Espírito ao deserto, onde foi tentado pelo demônio durante quarenta dias. Durante este tempo ele nada comeu e, terminados estes dias, teve fome (LC 4,1-2). Continua Lucas dizendo que depois das tentações “Jesus, então, cheio da força do Espírito, voltou para a Galileia. E a sua fama se espalhou por toda a região. Ele ensinava nas sinagogas e era aclamado por todos" (Lc 4,14-15). E ao ir à sinagoga de Nazaré, sua terra, assumindo para si o texto de Isaías, declara:

O Espírito do Senhor está sobre mim, porque me ungiu; e enviou-me para anunciar a boa nova aos pobres, para sarar os contritos de coração, para anunciar aos cativos a redenção, aos cegos a restauração da vista, para pôr em liberdade os cativos, para publicar o ano da graça do Senhor (Lc 4, 18-19).

Cheio do ES Jesus realizou essa sua missão. Foi na força do Espírito recebido no seu batismo que Jesus venceu a batalha contra o demônio e suportou as tentações. Foi sempre companhia do Espírito que Jesus realizou todas as suas pregações, que realizou todas as curas, que ressuscitou os mortos e realizou todos os milagres. Foi na companhia do ES, recebido no batismo, que Jesus assumiu e suportou sua paixão e morte de cruz.

\section{4 .2}

\section{A espiritualidade de Jesus}

Uma importante leitura sobre a "a experiência de Jesus no Espírito" é realizado por Moltmann, para ele é o Novo Testamento que oferece a base para a nossa busca pela experiência cristã do Espírito. Nele estariam anunciadas a história de Jesus como Messias de Deus e a história de Cristo com o Espírito. Dos sinóticos ele extrai a síntese da cristologia do Espírito, a fim de saber sobre a atuação do Espírito na morte de Jesus. Moltmann destaca que o Espírito é o

182 lbid., p. 35. 
sujeito da relação mútua entre Jesus e o Pai e através do Espírito, Jesus aprende seu papel messiânico. Ele relaciona o Espírito à Shekiná de Deus, demonstrando, assim, seu débito aos referenciais judaicos. Tal como o Espírito de Deus esteve presente com o povo de Israel, também com Jesus na história de sua vida ele se fez presente. ${ }^{183}$

A força vital de Deus, presente em Jesus, é operada pelo Espírito nele atuando. O mesmo Espírito conduz Jesus no papel messiânico e estreita suas relações com o Pai. Ele também conduz Jesus no caminho que lhe trará sofrimento e the confirmará a sua messianidade. Tal como a shekiná acompanhou o povo israelita, acompanhando-o em sua história, o Espírito se torna companheiro de Jesus em seu sofrimento. A relação é levada às últimas conseqüências, até que a paixão de um se torna a paixão do outro. ${ }^{184}$

Nesta intensa relação entre eles, o Espírito tem o seu destino ligado ao de Jesus e faz com que ele seja o Espírito de Cristo. Em outras palavras, Moltmann mostra a unidade primeira entre o Cristo e o Espírito. Assim, é o Espírito quem transforma Jesus no Cristo. Aqui Moltmann apresenta uma pneumatologia crucis, que é fundamentada nas Escrituras (Hebreus 9,14), o que o motiva explicar que "o valor da vítima não está unicamente na pessoa que é oferecida, mas também na maneira de sua entrega". ${ }^{185}$

O Espírito é a força que impulsiona Jesus a entregar a sua vida lhe dando sustentabilidade. Moltmann aqui apresenta um deslocamento do foco para o Cristo com a força do Espírito, ao dizer que não foi pela força da morte ou dos romanos que Jesus morreu, mas pela auto-entrega na força do Espírito. Entretanto, o Espírito não é apenas aquele que conduz Jesus até a morte na cruz, mas é também aquele que o ressuscita e o vivifica. Deste mistério da morte e da vida de Cristo, emerge para Moltmann o Espírito da vida. Ele chama a atenção para o fato de ser este um único mistério salvífico, sem ruptura cronológica. O que ocorre é uma unidade entre fé pascal e experiência pentecostal.

\footnotetext{
${ }^{183}$ MOLTMANN, Jürgen., O Espírito da Vida, p. 65-67.

184 Ibid., p. 68.

185 lbid., p. 69.
} 


\subsection{3 \\ A Experiência das comunidades primitivas}

A experiência da vida no Espírito, segundo Carlos Mesters, foi uma total novidade que se instaurou na vida das primeiras comunidades. Teria sido para elas como um novo começo, (Gl 6,15; 2Cor 5,7), um novo nascimento (Jo3,3-7), uma ressurreição ( $\mathrm{Rm} \mathrm{6,4;} \mathrm{FI} 3,10) .{ }^{186}$ As comunidades experimentam o $\mathrm{ES}$ em suas vidas e nos desafios concretos que se apresentam nos seu dia - dia, Ele é a força que vem do alto (Lc 24,49), Ele é a coragem para anunciar a Boa Nova (At 4,31), Ele faz perder o medo diante das autoridades (At 4,8.19) Ele é quem dá nova identidade a cada membro da comunidade como testemunha de Jesus (At $5,32 ; 15,28) .{ }^{187}$

Nas comunidades primitivas, o ES toca as pessoas nas suas várias dimensões da experiência. Podemos citar aqui, três destas dimensões: dimensão pessoal - experiências de situações limites (vida/morte), a dimensão relacional experiências que criam comunhão e a dimensão histórica - experiências que perduram por gerações.

\subsubsection{1 \\ Na dimensão pessoal}

O ES está na vida de cada um dos discípulos e apóstolos, ele coragem a Estevão para que ele vá até o martírio e coloca em cheque as crenças de Paulo diante da fé testemunhada por este (At 7,54-58). Ele está com Paulo no seu processo de mudança de vida, de conversão (At 9,3-9). Derrama o amor de Deus nos corações $(R m 5,5)$, socorre na fraqueza e reza por cada um e cada uma ( $R m$ 8,26-27), confere a vida que a letra mata (2Cor 3,6; $\mathrm{Rm} 6,8-10 ; 8,2.11$ ), defende a liberdade, pois é para a liberdade que Cristo nos libertou e diante da acusação ensina o que se deve dizer (Lc 12,12; Mc 13,11).

Ele é aquele que acolhe, cura e faz a pessoa ficar inteira, não só nas doenças, mas no ser humano na sua integridade (1Cor 12,9). Ensina a interpretar as Sagradas Escrituras, pela conversão faz cair o véu dos corações para que se possa verdadeiramente lê-las (2Cor 3,15; 1 Cor 10,1-3);

\footnotetext{
186 MESTERS, Carlos., Deus onde estás?, p. 24.

187 Ibid., p. 25.
} 
Sua ação ajuda a ler a realidade, faz viver na justiça e ligar fé e vida. (1Tm $3,16)$.

Dá coragem e fortalece para anunciar a Palavra de Deus (At 4,31) e enche de sabedoria aquele que a proclamam (At 6,10).

O ES geme, chora e intercede por cada um e cada uma, sonda o mais íntimo da realidade humana e exprime sua intercessão com gemidos inefáveis $(R m 8,26)$; faz participar do mistério de Cristo, pois pelo batismo fomos sepultados com ele na morte e por sua ressurreição viveremos uma vida nova $(\operatorname{Rm} 6,4-11)$.

\subsubsection{2 \\ Na dimensão coletiva}

Ele dirige a comunidade em todos os sentidos: inspira a redação do documento do Concílio (At 15,28), define o roteiro de viagem dos missionários (At 16,6-7), aponta rumos e direções (At 13,2), coloca pessoas para coordenar a comunidade (At 20,28).

Distribui uma variedade de dons, serviços e carismas na comunidade, mantendo a unidade, operando na diversidade (1Cor 12,1-11). Faz a comunidade se sentir mais ligada a Jesus, pois o mesmo Espírito que nele atuava é o que age na comunidade (LC 1,35).

Ensina a comunidade a viver o amor, a criar laços. Como diz a Bíblia: a capacidade de reconduzir o coração dos pais para os filhos e reconduzir o coração dos filhos para os pais (Ml 3,24; Eclo 48,8; Lc 1,17), ou seja "a capacidade de reconstruir a comunidade, o tecido social dentro das normas do amor". ${ }^{188}$

Reconcilia e perdoa. Pela força do Espírito a comunidade recebe o dom de perdoar e ser perdoado (Jo 20,22-23).

Unifica e congrega, na comunhão do Espírito todos se tornam um "não há mais judeus nem gregos, nem escravos nem livres, não há homem e mulher, todos se tornam um em Cristo" (GI 3,28);

O ES é quem constrói a comunidade, cada dom, cada carisma distribuído é para ser utilizado a serviço da comunidade (1Cor 12,7;14,26). A imagem do corpo simboliza uma unidade que mantém a diversidade (1Cor 12,14-21).

Envia em missão para anunciar a Boa Nova aos pobres, Ele unge para operar a libertação dos cativos, para recuperar a vista aos cegos, para proclamar a graça de Deus (Lc 4,18). Ele proclama a opção pelos pobres e marginalizados;

\footnotetext{
${ }^{188}$ MESTERS, Carlos., Deus onde estás?, p. 43.
} 
está presente na oração da comunidade, no louvor, no canto e na ação de graças (Ef 5,19-20; Cl 3,16).

\subsubsection{1}

\section{Na dimensão histórica}

A experiência do ES nas comunidades primitivas é lida sob o pano de fundo do Antigo Testamento; o ES é o prometido do Pai (Lc 24,29), eles agora são o novo Povo de Deus renascido em Pentecostes. As comunidades trazem para si experiência de seus antepassados.

Cada vez que a comunidade se reunia ao redor da Palavra e ouvia as narrativas da experiência do Espírito, vividas por seus pais e mães na fé, a comunidade alargava a certeza de aquele Jesus vindo de Nazaré, crucificado e ressurgido dos mortos, era o Messias, o Filho de Deus; e que o Espírito dado a eles por seu intermédio era o Espírito de Deus que esteve presente na vida de seus pais e estaria com eles até os confins da terra.

Em Pentecostes a comunidade, na figura dos apóstolos, assume plenamente essa certeza e a confiança que sua fé, mesmo na perseguição, mesmo diante do medo, é maior que eles, se espalhará por todos os povos e perdurará por gerações (At 2,5-12). Pentecostes é uma experiência vivida em diferentes dimensões: é pessoal, é situação limite, pois apóstolos vivem a tristeza da perda do mestre e o medo da morte, da perseguição. Nele eles encontram coragem, mudam, sentem no coração o fogo abrasador do ES que os transforma por dentro; é relacional, coletivo, comunitário, eles falam em línguas, expressam a experiência com muitos ali presentes e estendem a todas as nações a efusão do ES; é histórico, pois diante de todos proclamam a fé no Cristo Messias, no Filho de Deus e não só assumem a herança do seu povo como proclamam a eternidade desse Rei (assentado no trono do Pai) e se proclamam suas testemunhas. Testemunho esse que chegou até nós e do qual somos herdeiros.

Existem muitos outros aspectos e dimensões das experiências do Espírito e no Espírito, vividas pelas comunidades primitivas, que não mencionamos aqui, mas o que vimos até agora nos apresenta a caminhada de uma igreja onde o ES é a força vital, a energia que faz viver, sentir, amar, seguir e testemunhar Jesus Cristo. Pois o Espírito que se manifesta nas comunidades com tanta força e variedade não é outro a não ser o Espírito de Jesus. ${ }^{189}$ Uma experiência que dá sentido a vida de cada pessoa da comunidade e da comunidade num todo, que

${ }^{189}$ MESTERS, Carlos., Deus onde estás?, p. 41. 
inspira, que cria comunhão e que é duradoura. E acima de tudo, que respeita a força e a liberdade desse Espírito que não se deixa prender nas artimanhas humanas e institucionais e com ele busca ser livre, "pois onde se encontra o Espírito do Senhor aí está a liberdade" (2Cor 3,17).

\subsection{4}

\section{A Experiência da comunidade do Discípulo Amado}

Merece nesse nosso estudo, uma reflexão a parte sobre a experiência que a comunidade do Quarto Evangelho (QE) faz do ES. Acreditamos que possa ser a Comunidade do Discípulo amado o paradigma para a vivência de uma intensa relação de amor com Jesus Cristo e com o ES nos enviado por ele. Uma relação que possibilitou aquela comunidade viver "um cristianismo desafiadoramente diferente e volátil - tão volátil que estava destinado a ser absorvido nos movimentos cristãos mais amplos". ${ }^{190}$ Essa comunidade que não conheceu Jesus, cuja fé chegou até eles pelas testemunhas que o anunciaram (Jo 1,35-51), ${ }^{191}$ testemunhar a fé em Jesus é para comunidade do QE condição básica para o amadurecimento e a superação das crises e desafios, e quem dá primeiro testemunho é o ES.

A teóloga Ana Maria Tepedino, em seus estudos sobre a comunidade do $\mathrm{QE}$, nos alerta para o fato de que na comunidade joanina, o ES não é uma força, uma energia, mas é uma pessoa e tem um nome: "Paráclito-advogado, ele é o acusador do mundo, o defensor, a testemunha, o apoio, o consolador, o mestre e a memória viva da comunidade, é quem inspirará o verdadeiro seguimento de Jesus". ${ }^{192}$

No QE, o Paráclito é aquele que é enviado por Jesus para que a comunidade não se sinta só, órfão, angustiada. Permanece na comunidade para que esta permaneça fiel a Jesus. ${ }^{193}$ A comunidade joanina está sofrendo por causa da perseguição. Ela foi expulsa da sinagoga, porque proclamava Jesus como Messias e Filho de Deus. ${ }^{194} \mathrm{Na}$ experiência de angústia ela não se sente abandonada, tem ao seu lado o Paráclito, o consolador. Companhia que é vivenciada por todo o $\mathrm{QE}$, mas que surge de forma especial nos discursos de

\footnotetext{
190 BROWN, Raymond Edward., A comunidade do discípulo amado, p. 9.

191 TEPEDINO, Ana Maria., "Das trevas da Angústia à consolação do Amor”, p. 55.

192 lbid., p. 53.

193 Ibid., p. 54.

194 lbid., p. 56.
} 
despedida $(13,31-14,31 ; 15,1-16,4 a ; 16,4 b-16,33)^{195}$, que "têm a função de libertar a comunidade da angústia das perseguições; de fortalecê-la na fé, de infundir a confiança espiritual de Jesus no meio da comunidade através de seu Espírito". ${ }^{196}$ Para a comunidade do discípulo amado o Paráclito é alguém que está com ela, e que a ajuda a ultrapassar o ódio do mundo em relação a ela. O mesmo ódio que ela entende ter sido sentido em relação ao seu Mestre. Por isso ela narra a história de Jesus tão intimamente associada à sua. ${ }^{197} \mathrm{O}$ Espírito possibilita uma auto identificação de experiências entre Jesus e a comunidade e ao narrar sua história, se insere na angústia, morte e ressurreição do próprio Jesus.

Para que haja essa identificação é preciso ser, cada vez mais, introduzido na "verdade plena", e é o Espírito quem possibilita essa revelação. ${ }^{198}$ Ele é o mestre que interpretará corretamente o significado das palavras de Jesus. Assim como Jesus revela o Pai na terra, o Paráclito revela Jesus. O Espírito Paráclito faz com que a unidade que os discípulos alcancem, signifique também sua plena realização $(17,23)$, a qual chegará a seu termo no seio da comunidade.

A força divina, revelada pelo Espírito Paráclito, penetra nos que crêem pela revelação de Jesus, para que esteja neles o amor com que Deus ama seu Filho. O amor que brota de Deus é fonte originária, é um elo vinculante, não só do Pai com o Filho, mas também entre os crentes. A existência da unidade na comunidade, onde reina o amor sem limites, deve ser o elemento primordial da missão de cada membro da comunidade.

A comunidade joanina não baliza sua fé pelos milagres extraordinários, mas pela palavra, pelos frutos de amor fraterno que realiza a própria comunidade e pela vivência da verdade, que para ela significa amar, viver e andar como Jesus, fazendo dela suas opções. ${ }^{199} \mathrm{E}$ o Espírito é o companheiro que auxilia nessa batalha, para vencer o mundo, encarnar-se nele e permanecer no amor.

Os primeiros cristãos releram essa amor sob a luz da encarnação, morte e ressurreição de Jesus. E nós buscamos no Espírito Santo os dons e carismas, para que a Igreja, nossa comunidade de fé, possa experimentar dentro e fora dela a presença do Espírito de Deus. É o Espírito o principio vivificador da fé e da Igreja como nos diz Irineu:

(Fé) recebida da Igreja e que nós guardamos, (fé) que sempre, sob a ação do Espírito de Deus, como licor precioso conservado numa vasilha de boa qualidade,

\footnotetext{
${ }^{195}$ Ana Maria Tepedino destaca que estes discursos se tratam de um gênero literário utilizado como testamento. Ibid., p. 57.

196 TEPEDINO, Ana Maria., “Das trevas da Angústia à consolação do Amor”, p. 58.

197 Ibid.

198 lbid., p. 59.

199 lbid.
} 
rejuvenesce e faz rejuvenescer a vasilha que o contém. De fato, a Igreja de viu depositária desse dom de Deus, do mesmo modo como Deus enviou seu sopro à carne modelada, para que todos os membros recebam dele a vida; e nesse dom estava contida a intimidade do dom de Cristo, isto é, o Espírito Santo. [...] Porque aí onde está a Igreja (a ecclesia), ai também está o Espírito de Deus; e aí a Igreja e toda a graça. E o Espírito é a verdade. ${ }^{200}$

No próximo capítulo vamos então apontar os caminhos pneumatológicos das CEB's. Entender como as ccomunidades vivem a partir de uma cristologia pneumática, e os desafios que essa vivência aponta nos dias de hoje.

Não sendo este um estudo de pneumatologia , mas uma tentativa de uma "eclesiologia da experiência", consideraremos como ação do Espírito de Deus dentro desta experiências eclesial, tudo que a move e transforma. Ou seja, a "sinergia produzida pelo Espírito" 201 em prol da Missão da Igreja.

200 Adv.Haer.III, 24,1 (7,966; v.II,p. 131; S. Chr.pp. 399). Apud CONGAR,Yves., Creio no Espírito Santo 1, p. 96-97.

201 Sinergia ou sinergismo deriva do grego synergía, cooperação sýn, juntamente com érgon, trabalho. É definida como o efeito ativo e retroativo do trabalho ou esforço coordenado de vários subsistemas na realização de uma tarefa complexa ou função. Quando se tem a associação concomitante de vários dispositivos executores de determinadas funções que contribuem para uma ação coordenada, ou seja, o somatório de esforços em prol do mesmo fim, tem-se sinergia. O efeito resultante da ação de vários agentes que atuam de forma coordenada para um objetivo comum pode ter um valor superior ao valor do conjunto desses agentes, se atuassem individualmente sem esse objetivo comum previamente estabelecido. O mesmo que dizer que "o todo supera a soma das partes". O que aqui chamamos de "sinergia do Espírito" ou "sinergia produzida pelo Espírito" é a criatividade do Espírito que movimenta as forças vivas da Igreja em prol de sua missão da Igreja 


\section{4}

\section{A experiência do Espírito de Deus nas CEB's}

Para quem vive em uma comunidade eclesial de base, as dimensões da experiência se permeiam; as experiências pessoais, a vida da comunidade, a participação na história são vivenciadas como se fossem uma só coisa. A consciência encarnada da comunidade, instaurada pela visão messiânica do Reino anunciado por Jesus, faz com que cada membro se sinta uma porção do Povo de Deus, co-responsável pela prática e a construção da justiça prometida por este Reino.

As experiências de situações-limite, as dificuldades que atingem a comunidade, a pertença de cada um e cada uma no processo de transformação da sociedade, são facetas de uma identidade muito bem definida: a de ser Povo de Deus, seguidores de Jesus e destinatários do Reino.

As pessoas que estão nas CEB's, vivenciam suas experiências de vida à luz de sua espiritualidade, e esta sempre foi envolvida pela dinâmica do seguimento de Jesus Cristo. Trata-se de uma espiritualidade marcada por um tríplice movimento: êxodo, compromisso e proximidade ${ }^{202}$. Uma dinâmica que, a nosso ver, começa de fora para dentro. Começa na sua dimensão histórica, na autoidentificação com um Povo; passa pela dimensão comunitária, criando laços de comunhão no seguimento de Jesus e terminam na dimensão pessoal, na experiência amorosa de um Deus que nos ama na nossa pobreza. Não só ama como faz opção pelo pobre.

\section{1}

\section{Dimensão histórica - Povo de Deus congregado pela Palavra}

Para a CEB's, ser Povo de Deus é o que dá identidade a existência de uma comunidade, de um grupo, de uma pessoa. Ser Povo de Deus é ontologicamente experimentar a premissa de que o Deus libertador do Êxodo é o mesmo que acompanha a comunidade nas lutas, nos desafios, nas vitórias e esperanças

202 TEIXEIRA, Faustino., "Espiritualidade do Ecumenismo e do Diálogo Inter-religioso”, p. 130. 
cotidianas. À luz do Êxodo ou Libertação da Escravidão do Egito, se relê e interpreta os fatos históricos e a história pessoal.

Nessa identificação, o Êxodo não só aconteceu por volta de 1250 a.C; ele acontece e sempre acontecerá enquanto houver na comunidade, cativos e oprimidos que clamem ao Senhor pedindo justiça. E a comunidade crê, que o Senhor sempre virá em seu favor. Manifestar-se-á como Deus libertador, realizando o Êxodo e gerando sempre um Povo Novo. ${ }^{203}$

A esperança é o dinamizador desta caminhada, e "quando a esperança de um povo é forte, ela engravida a história", afirma a biblista Mercedes Lopes. ${ }^{204}$ Esta é a auto compreensão que as CEB's têm de sua existência e missão, animadas pelo desejo de libertação e pela presença do Deus libertador que escuta o clamor dos empobrecidos (Ex 3,7-10), elas estão sempre à espera, se preparando para a grande "saída" (Ex 12,11). A vida de cada comunidade se insere dentro de um processo de Éxodo permanente, onde cada luta, cada desafio, cada dor, pertence à esfera da travessia.

Este processo libertador que começou com a solidariedade transgressora entre mulheres egípcias e hebréias (Ex 1,15-22), com a criatividade da mãe e da irmã de Moisés (Ex 2,1-4) e com a adoção do menino pela filha do Faraó (Ex 2,510); encontra eco no coração das comunidades eclesiais de base, onde homens e mulheres descobrem na solidariedade a perspectiva de esperança que faz romper o silêncio diante das estruturas de pecado da sociedade.

Exxodo é então evento fundante, é modelo fundamental do pensar e agir: a passagem da opressão para o Reino de Deus. Nas palavras de Leonardo Boff, na década de 70: que "por um lado, a libertação é concebida como superação de toda escravidão; por outro, como vocação a ser homens novos, criadores de um mundo novo". ${ }^{205}$

$\mathrm{Na}$ releitura do Êxodo, as CEB's constroem sua memória e experiência coletiva; e inserem seus membros no passado, presente e futuro da linhagem dos que creem no Deus da Libertação. ${ }^{206}$ Nesta linhagem não existe fé no singular, mas no plural. Logo o decisivo não é ter ou não ter fé (teórica e verbal), mas: acreditar em quê e em quem? As CEB's acreditam no Deus Javé, solidário e

\footnotetext{
203 CEBI., Leitura Orante da Bíblia, p. 43.

204 Nos dias 25-29/07/2011, realizou-se o Curso do Rio com o tema: Sociedade do Bem-Viver: Cidadania, Fé e Vida no Planeta. Esta afirmação foi feita por Mercedes Lopes, na assessoria no curso, que tinha por tema: Propostas bíblicas do Bem-Viver: A Cartilha da Caminhada (Ex 15-18) e a prática de Jesus.

205 BOFF, Leonardo. Apud SUNG, Jung Mo., "Tarefas do Cristianismo da Libertação".

206 Cf. LEGER. Danièle Hervieu., O Peregrino e o convertido, p. 27.
} 
libertador, o mesmo Deus que acompanhou Abraão, Moisés, os profetas, Jesus, os primeiros cristãos, os mártires de ontem e de hoje. ${ }^{207}$

Nesta experiência coletiva de ser Povo de Deus, o Espírito é aquele que sustenta na luta, é Deus mesmo presente na caminhada, dando forças diante das dificuldades, ouvindo os clamores, sendo condição e possibilidade de viver plenamente a liberdade sonhada.

É a Ruah de Deus que toma a face da terra e renova as criaturas, que é em si espaço de criatividade e transformação. Que concede ao Povo Novo a coparticipação nas experiências de escravidão, na reconquista da terra, na sabedoria de vida, na contemplação da criação, na oração comunitária, no sofrimento do exílio e na vocação profética; tudo quanto viveu o Povo eleito, é agora herança e compromisso da comunidade eclesial de base.

A eleição é assumida como caráter primordial da identidade da comunidade, rezada nas orações:

Reunimo-nos como povo de Deus bem-aventurado, que celebra a força dos pobres; que enxuga as lágrimas dos que choram; que cultiva a mansidão; que sacia a fome e a sede na prática da justiça; que exercita a misericórdia; que de coração limpo contempla a face de Deus na promoção da paz; que com perseverança enfrenta perseguições e injúrias todos os dias. Somos povo, no entanto misericordiosos; pobres, porém mansos; famintos e sedentos, mas justos; perseguidos e injuriados, e, ainda assim, pacificadores. Somos o que somos pela graça de Jesus Cristo, nosso Senhor. Somos o que somos pelo amor de Deus, nosso Pai. Somos o que somos, pelas misericórdias do Espírito Santo, nosso eterno consolador. ${ }^{208}$

Ao assumir sua identidade como Povo de Deus, Povo que caminha rumo a libertação, as comunidades compreendem o papel da ação salvífico de Deus na história e assumem nela seu compromisso com a transformação deste mundo.

A moderna compreensão da realidade como "história" é uma compreensão etnopolítica daquela história que é feita pelos homens. Por isso a experiência histórica de Deus coincide com a experiência ética do próximo: Não pode existir conhecimento histórico sem a pratica da justiça. ${ }^{209}$

Esse compromisso é reafirmado na luta pela justiça e igualdade social, cada pessoa da comunidade se sente comprometida não só com as causas da comunidade, mas também com todas as dores que oprimem o mundo criado. Sentem-se chamados a estar na história, ser história e fazer a história. Por isso o compromisso das CEB's e sua participação na causa dos sem-terra, dos

${ }^{207}$ MOREIRA, Gilvander Luis. Espiritualidade viva nos acampamentos e assentamentos dos semterra. Apud CEB'S., Espiritualidade Libertadora, p. 135.

208 Acolhida do povo de Deus, oração composta por Luiz Carlos Ramos, baseado em Mateus 5.1 12: As Bem-Aventuranças. Celebrada no 11 Intereclesial da CEB's na Diocese de Itabira/ Cel. Fabriciano - MG, em Julho de 2005. Lá estivemos com um grupo de 5 alunos e duas professoras do Departamento de Teologia da Puc, como pesquisadoras.

209 GUTIÉRREZ, Gustavo., Teologia da Libertação, p. 179. 
indígenas, dos afrodescendentes, das mulheres, dos encarcerados e de tantos outros excluídos.

Esse compromisso histórico e ético com a lgreja Povo de Deus está presente na confissão de fé, não só dos leigos, mas também dos pastores comprometidos com as CEB's, como relata Dom Pedro Casaldáliga ao falar o início de seu episcopado:

Sou bispo desde o dia 23. Minha consagração episcopal foi na máxima simplicidade e dentro de um realismo de compromisso e de entrega inevitáveis. Acompanharamme muitos amigos. E o Espírito de Jesus esteve muito presente. Nem grandes emoções, nem temerosas responsabilidades. Como uma nova confirmação. Como a exigência suprema. Sou apóstolo, bispo da Igreja de Jesus. Devo confiar no Espírito do Senhor Ressuscitado que anima a sua Igreja. Devo servir o Povo de Deus com toda liberdade e dedicação. ${ }^{210}$

Ainda Bispo da Prelazia de São Féllix do Araguaia, no início do seu episcopado, Dom Pedro já anunciava seu amor pela Igreja dos pobres, pelas comunidades de base, pelos povos indígenas que habitam aquela porção da Amazônia explorada. Se inseria como batizado, sacerdote, e pai dos crentes, na linhagem do Povo de Deus. Muitos foram os bispos que deram testemunho desta linhagem e alimentaram a caminhada das CEB's: Dom Helder Câmara, Dom Luciano Mendes, Dom José Maria Pires, Dom Fragoso, Dom Mauro Morelli, Dom Valdir Calheiros, e tantos outros mais.

A cada celebração da palavra, a cada eucaristia, a cada encontro, nas reuniões, nas manifestações, a luta pela libertação assume caráter atemporal, vira bandeira, canto que anima o povo na sua marcha para Canaã celeste, o Reino de Deus que, pela força do Espírito, começamos a construir aqui neste tempo que nos é dado viver.

\subsection{1}

O Espirito e a Palavra: a leitura da Bíblia como identificação histórica

Quando citamos anteriormente Ireneu ao afirmar que "Ecclesia, ib et Spiritus Santus, et ubi Spiritus Dei,illic Ecclesia et omnis gratia: Spiritus atem Veritas": ("Onde está a Igreja ai está também Espírito Santo, e onde está o Espírito de Deus aí está a Igreja e toda graça: pois o Espírito é a Verdade".) temos conhecimento de que ele falava da epliclese, esta relação da Igreja com o Espírito

${ }^{210}$ CASALDÁLIGA, D. Pedro., Creio na justiça e na esperança, p. 48. 
Santo, desta permanente invocação e incondicional abertura para as experiências do Espirito que cria comunhão e faz viva a vida. ${ }^{211}$

Mas devemos lembrar que, como batizados, somos incorporados ao corpo de Cristo e fazendo parte da linhagem dos que creem e todas as vezes que proclamamos a Palavra tornamos presente ali a Igreja desse mesmo Cristo.

Apesar das muitas acusações pelas quais passou, as CEB's nunca quiseram ser outra Igreja, pelo contrário sempre estiveram mesmo nas divergências teológicas, ligadas aos seus bispos e pastores. No entanto, suas ausências nessas comunidades, potencializou muitas vezes aquela que é talvez a maior riqueza desta experiência eclesial: a proximidade com a Palavra de Deus.

Da grande maioria das CEB's pode-se afirmar que são Igreja da Palavra fundacionalmente porque nasceram como pequenos grupos reunidos em torno da Palavra de Deus e cresceram e se fortaleceram como "ouvintes da Palavra". A primeira frase da Constituição Dogmática sobre a Revelação do Vaticano II: Dei verbum religiose audiens..., "ouvindo religiosamente a Palavra de Deus...", que é aplicada a Igreja reunida em Concilio, pode ser aplicada também com toda verdade às CEB's. A Palavra de Deus, "ouvida religiosamente", é a força que as liga e religa como comunidades. "É a Palavra de Deus que nos reúne em comunidade", lemos, por exemplo, no relatório de Chapecó, enviado para o IV Encontro Intereclesial. ${ }^{212}$

A proximidade com a Palavra nas comunidades é mais que escuta atenta do relato de fé, ela é a aproximação da vida do povo da comunidade com o povo da Bíblia. A palavra do Evangelho proclamada nos vários momentos celebrativos da comunidade, presencializa Cristo: "Quem vos ouve a mim ouve". "Ela atravessa a história chegando até nós porque tem consigo a promessa dele. Permanece conosco de uma geração a outra geração, porque antecipa o futuro de Cristo na luz universal da nova criação". ${ }^{213}$

A comunidade, Igreja que procede da mutua relação entre Filho e Espirito, entre Espírito e Palavra ${ }^{214}$ é chamada a vivenciar, a ser sinal do anúncio que acolheu.

Nas CEB's, a partir da leitura das histórias bíblicas, as pessoas reconhecem sua própria situação histórica e experimentam em comum o Espirito que as liberta. Ele não só ajuda a compreender as escrituras mais trabalha na transfiguração da corporeidade, ajuda-nos na meta de sermos um outro Cristo.

É verdade que em muitas destas comunidades as pessoas mal sabem ler, quando partilham a Palavra nos círculos bíblicos fazem uso da oralidade. A

211 MOLTMANN, Jürgen., O Espírito da Vida, p. 218.

212 BARREIRO. Álvaro. "As Comunidades Eclesiais de Base como modelo inspirador da nova evangelização", p. 340.

${ }^{213}$ MOLTMANN, Jürgen., Op. cit., p. 219.

214 lbid., p. 220. 
memória é a como uma agulha que numa costura vai juntando pedaços, resgatando no inconsciente de cada um e cada uma, a ação de Deus que the liberta e aproxima do outro.

Muito comum, na experiência da Leitura Orante da Bíblia, quando se pede para que cada um repita um trecho do texto bíblico que mais lhe chamou a atenção, surgirem palavras e expressões que vêm de outros textos ou da própria vida que na lembrança é trazido à tona para ser partilhado.

Mas lembrar não é apenas evocar um conceito de passado por meio do outro, atual. A memória, antes de ser um filme rebobinado à cena inicial que nos interessa recuperar, elabora uma série de sensações, sentimentos, percepções e imagens para, só então, "construir-se" como referente. ${ }^{215}$

Como uma colcha de retalhos, a memória reconstrói a história com a vida de pessoas, que se encontram na história bíblica e se reconhecem naquele povo.

O processo de descoberta e afirmação do eu tem, então como elemento constituinte fundamental a tomada de consciência da própria história, o entrelaçamento das memórias pessoais e sociais, o situar-se no tempo entre os homens. Esse exercício desencadeia a valorização do sujeito, desautomatiza o estar no mundo "como qualquer outro" e começa a conferir uma certa identidade a cada ser humano. ${ }^{216}$

A leitura popular da Bíblia, vivenciada na maioria das CEB's, com seu triangulo hermenêutico: realidade - texto/Bíblia - comunidade muito auxilia neste processo de construção identitária. O método que é caracterizado pela sua circularidade, abre sempre para novas perspectivas, a realidade em que se vive é o chão que determina é a porta de entrada no texto bíblico. A vida, em sua concretude, com suas mazelas e prazeres, com seus sonhos e dissabores, é o lugar onde se articula e se entretece a Palavra de Deus. ${ }^{217}$ É nesta experiência de encontro de vidas que age o Espírito de Deus, amalgamando o chão do cotidiano da comunidade que deixa de ser massa, para ser povo que se olha, se reconhece e se identifica como ouvintes da Palavra.

\section{2 \\ Dimensão comunitária - A comunidade dos seguidores de Jesus}

Nas CEB's as experiências que criam comunhão nascem do dia-dia da do povo, onde Deus se revela e o convoca a viver em comunidade e ali realizar o seu

\footnotetext{
215 YUNES. Eliana., Tecendo um leitor, p. 22.

216 lbid., p. 23.

217 NEUENFELDT, Elaine G., "Diálogo entre Leitura Popular e Leitura Feminista”, p. 117.
} 
plano salvífico. O projeto de Deus para o ser humano é então a comunhão com o outro e com Ele. Toda graça é comunitária, toda graça conduz e reconduz à comunidade. É o modelo da narrativa de Emaús, tristes com o coração sombrio, desesperançados, de espíritos sem inteligência e tardos do coração, caminham para longe da comunidade. Encontrando-se com Cristo, reconhecendo-o no partir do pão, voltam com o coração ardente para Jerusalém, símbolo de toda comunidade eclesial (Lc 24,13-35). ${ }^{218}$

Vamos elencar aqui a missão e a celebração, como duas experiências intimamente ligadas, onde o encontro com Jesus Cristo vivo cria laços de união e comunhão nas comunidades de base.

Como missão, entendemos a prática do seguimento de Jesus pela comunidade, as obras de justiça - consequência lógica da fé (cf. 1Jo 3,12); e como celebração, entendemos a liturgia, a oração, a festa, experiências simbólicas da espiritualidade e da fé partilhada pela comunidade. Ambas se articulam, uma passa pela outra. ${ }^{219}$ Ambas se implicam, mas possuem linguagem própria, perpassam o sujeito da experiência de formas diferentes, em níveis e camadas distintas na razão e na subjetividade.

\subsection{1}

\section{A Missão - seguir Jesus}

A experiência das CEB's encontra na prática de Jesus os fundamentos para balizar o seu sonho: reconstruir uma Igreja da misericórdia, que faça descer da cruz os povos crucificados e que se torna co-responsável na construção de uma solidariedade universal, sobretudo com os pobres e excluídos. Todas as vezes que a comunidade vive este seguimento, ela reafirma a unidade do corpo (comunidade-igreja) com a cabeça que é Jesus Cristo.

A Boa Nova da pessoa de Jesus é proclamada a todas as mulheres e homens da comunidade e os convida a construir uma nova sociedade fundamentada na justiça e no amor, possibilitando que sejam felizes. ${ }^{220}$ Esta felicidade é compreendida e vivenciada sob forma de aproximação da comunidade com a pessoa de Jesus e seu modo de vida. O Jesus que andava por cidades e aldeias pregando a chegada do Reino de Deus, que estabelecia relações

${ }^{218}$ LIBÂNIO, João Batista., Teologia da Revelação a partir da modernidade, p. 449.

219 TEPEDINO, Ana Maria., "A espiritualidade do seguimento de Jesus no compromisso com os excluídos: Fora do amor não há salvação", p. 70.

220 lbid. 
profundas por onde passava, que estava sempre junto aos pobres, os doentes, os marginalizados, que não aceitou a injustiça e na luta contra esta foi às últimas consequências: foi assassinado na cruz. Um Jesus que no amor viveu, por amor morreu, e pela força do amor ressuscitou.

A pessoa de Jesus e o seu amor são então presença real e testemunho de vida para a comunidade eclesial de base, que tem no evangelho sua definição de como se viver este amor no seu tempo histórico:

Hoje, amar é buscar praticar a justiça, lutar pelos direitos humanos, viver a solidariedade entre nós. Cada parte do evangelho vai insistir nesta vivência concreta. Essa mística afetiva nos lança numa prática ética. Ética de cuidado com a vida, de defesa da vida, especialmente da vida sofrida, onde ela se encontra ameaçada, tanto seres humanos, como a natureza. ${ }^{221}$

As comunidades eclesiais de base assumem como sua vocação específica o testemunho vivo em favor do Reino de Deus e de seus traços na história. Enfatizam os valores fundamentais da solidariedade e da acolhida ao outro, sobretudo daqueles mais pobres e excluídos. Vivem e partilham a alegria de conhecer e seguir Jesus Cristo. Não escondem a riqueza de um encontro que é fruto do amor. Entendem também que a verdadeira compreensão de Jesus passa pela abertura ao mistério do Reino de Deus e pela realização histórica da vontade do Pai.

A proclamação de Jesus Cristo ganha nas CEB's um itinerário peculiar. Para as comunidades a proclamação se traduz pelo modo de vida, pelo testemunho, pelos atos e pelo diálogo com o diferente. $\mathrm{E}$ o testemunho fala muito mais forte, pois é resultado de uma caminhada de vida que busca em Jesus Cristo o seu horizonte e modelo: viver como ele, no meio dos outros, dos que sofrem e são excluídos, de buscar a realização de uma hospitalidade sagrada.

Por sua vez, o cristianismo de libertação, mais historiocêntrico, criou as Comunidades Eclesiais de Base e as Pastorais engajadas: elas criam uma espiritualidade em torno do seguimento do Senhor Jesus na práxis histórica libertária, questionando assim os senhores deste mundo injusto e militando gratuita e vigorosamente por um mundo melhor. ${ }^{222}$

Esta militância se dá sempre na perspectiva da esperança. Mesmo sendo em sua maioria as comunidades, formadas pelos pobres e excluídos da sociedade, aqueles e aquelas que vivem sob a sombra da desesperança imposta pela sociedade, na vivência do evangelho em comunidade se aprende a espera.

221 Ibid., p. 78.

222 ARAGÃ̃, Gilbraz. "Inculturação da fé cristã na religiosidade popular", p. 12 


\begin{abstract}
É importante saber: eu posso sempre continuar a esperar, ainda que pela minha vida ou pelo momento histórico que estou a viver aparentemente não tenha mais qualquer motivo para esperar. Só a grande esperança-certeza de que, não obstante todos os fracassos, a minha vida pessoal e a história no seu conjunto estão conservadas no poder indestrutível do Amor e, graças a isso e por isso, possuem sentido e importância, só uma tal esperança pode, naquele caso, dar ainda a coragem de agir e de continuar. Certamente, não podemos « construir » o reino de Deus com as nossas forças; o que construímos permanece sempre reino do homem com todos os limites próprios da natureza humana. O reino de Deus é um dom, e por isso mesmo é grande e belo, constituindo a resposta à esperança. ${ }^{223}$
\end{abstract}

É no encontro com o outro que espera, que luta, que sofre como qualquer ser humano, seja ele rico, pobre, homem, mulher, criança, idoso ou jovem que a igreja que está na base se reconhece como comunidade peregrina. Comunidade que nas lutas do dia-dia se entrega a causa da justiça, que responde a esperança na da missão evangélica de construção do Reino de Deus.

É importante lembrar que a experiência das comunidades de base é de uma cristologia pneumatológica, Cristo age movido pelo Espírito,

A inhabitação do Espirito leva a força vital de Deus em Jesus a uma efusiva plenitude. Jo3,34 o dom único do Espírito de Jesus "dom sem medida". Com Ele começa o Reino de Deus e a nova criação de todas as coisas. O Espirito faz de Jesus o Reino de Deus em pessoa: Na força do Espirito Jesus expulsa os demônios e cura os enfermos. Na força do Espírito acolhe os pecadores e leva aos pobres o Reino de Deus. ${ }^{224}$

A missão é sempre vista sob a luz da força do Espírito.

Se foi na força do Espírito recebido no seu batismo que Jesus venceu a batalha contra o demônio e suportou as tentações, é por ela que a comunidade enfrenta a o mal.

\begin{abstract}
Uma vez desarmado Satanás, Jesus pode anunciar a expulsão dos" maus espíritos "que assombram o homem com doenças e todos os males possíveis, como manifestação histórica do reino de Deus. Isto se atualiza de modo simbólico e real. Isto significa que o reino de Deus não está esperando no "céu" ou em um "novo era" como um estado fixo, de prontidão, mas aparece como um processo onde o amor de Deus integra cada vez mais, a nossa história na vida atual salvando-nos e nos libertando, e adquire uma crescente transparência em nossa realidade histórica. $\mathrm{O}$ anúncio do Evangelho e os prodígios de Jesus (suas curas, sua comensalidade com os pecadores, cobradores de impostos e as prostitutas; alimentar os famintos, perdoar os pecados e etc.) são os "pontos de transparência "o reino de Deus se instaurando aqui e agora. [ ...] Nessa conduta se pode tocar a vontade salvadora de Deus para com Israel. Deus se aproxima de seu Povo na pessoa e na obra de Jesus, sentando-se à mesa com ele, limpando os leprosos, curando os enfermos, acolhendo os pecadores. ${ }^{225}$
\end{abstract}

\footnotetext{
223 BENTO XVI. Spe Salvi.

${ }^{224}$ MOLTMANN, Jürgen., O Espírito da Vida, p. 68.

225 "Una vez desarmado Satanás, Jesus puede anunciar la expulsión de los "malos espíritus" que atormentan al hombre con enfermidades y con todos los males posibles, como manifestación histórica el reino de Dios. Este se actualiza ahi de modo <<simbólico-real >>. Esto significa que el reino de Dios no está aguardando em el "cielo" o em um "nuevo eón" como um estado fijo y dispuesto, sino que aparece como um processo del amor de Dios que integra más y más nuestra história actual
} 
Se foi sempre na companhia do Espírito que Jesus realizou todas as suas pregações, que realizou todas as curas, que ressuscitou os mortos e fez todos os milagres; será esta companhia que irá curar as feridas, sanar as dores e consolar nas perdas. Se foi na companhia do Espírito, recebido no batismo, que Jesus assumiu e suportou sua paixão e morte de cruz, será este mesmo Espirito que, se preciso for, irá com a comunidade até o martírio.

A experiência vivida pelos mártires alimenta o coração da missão do seguimento de Jesus desde o nascimento das CEB's, elas se entendem como flor sem defesa, regada pelo sangue dos mártires. O exemplo dos mártires não é uma meta, não se deseja a morte, mas ela é encarada como consequência da opção de viver o Evangelho com toda sua radicalidade.

$\mathrm{Na}$ experiência eclesial de algumas Igrejas da América Latina e do Caribe, as Comunidades Eclesiais de Base têm sido escolas que têm ajudado a formar cristãos comprometidos com sua fé, discípulos e missionários do Senhor, como o testemunho, a entrega generosa, até derramar o sangue, de muitos de seus membros. Elas abraçam a experiência das primeiras comunidades, como estão descritas nos Atos dos Apóstolos (At 2,42-47). ${ }^{226}$

O martírio é a experiência mística, daqueles/as que não deixam que as prisões do medo e as incertezas diante da noite escura trazida pela perseguição, os afastem do testemunho da verdade,

É hora de assumirmos compromisso com a herança espiritual e profética dos mártires das Comunidades Eclesiais de Base, tais como "Zé Maria, assassinado com oito tiros, animador da CEB de Limoeiro do Norte, CE, na Chapada do Apodi, presidente da Associação dos trabalhadores rurais, que denunciam as intoxicações de trabalhadores e até de crianças e a poluição provocada pelas nuvens de agrotóxico despejadas pelos aviões das produtoras de frutas, sobre os abacaxis, as mangas e as bananas, sobre o açude, o campo de bola e a escola, seguindo o capricho dos ventos....".227

O testemunho diante das forças de morte é um legado deixado a CEB's, por aqueles/as que, sob a força do Espirito, souberam permanecer no amor aos pequenos e as causas do Reino de Deus, aqueles/as cujo destino se conformou ao de Cristo,

en em vida salvadora y liberadora de Dios y adquiere así uma creciente transparência em nuestra realidad histórica. El anuncio del evangelio y los prodígios de Jesús (sus curaciones, el ser comensal de pecadores, recaudadores y prostitutas mel dar de comer a los hambrientos, el perdonar los pecados, etc) son esos "puntos de transparência" del reino de Dios instaurado aqui y ahora.[...] Em esta conducta de Jesús se puede palpar com las manos la vontade salvífica de Dios para con Israel. Dios se aproxima a su Pueblo em la persona y la obra de Jesús, sentándose a la mesa con él, limpiando a sus leprosos, sanando a sus enfermos, acogiendo a sus pecadores". KELL, Medard. Escatologia, p. 139.

226 DA, n. 178.

227 VV.AA. Justiça e Profecia a serviço da vida, p. 343. 
Nosso Brasil e nossa América constituem o Continente da morte com esperança. Dirigimo-nos a vocês em nome de todos os nossos Povos e nossas Igrejas, pois a vocês devemos a coragem de viver, defendendo nossa identidade e a vontade teimosa de seguir anunciando o Reino, contra o vento e a maré do anti-reino neoliberal e apesar das corrupções de nossos governos ou de todos os nossos temores, recuos e covardias. Cremos que enquanto houver profecia haverá credibilidade, enquanto houver martírio, haverá esperança. Enquanto houver Profetas e Mártires haverá CEB's lutando por "Justiça e profecia a serviço de vida". A história das CEB's se mistura com a luta dos pobres por sua dignidade, por seus direitos. Do chão das CEB's é que surgiram os Profetas e os Mártires [...] Com São Romero da América e com todos vocês e unidos à sua voz e ao compromisso comum de todos os irmãos e irmãs de solidariedade que nos acompanham, declaramo-nos "felizes por correr, como Jesus e como vocês, os mesmos riscos, por nos identificarmos com as Causas dos pobres e excluídos". Neste chão nordestino queremos gravar para sempre em nosso coração as últimas palavras de nosso pastor profeta D. Hélder Câmara: "Não deixem morrer a profecia!". ${ }^{228}$

O compromisso com a dimensão profética do Reino, é assumido em cada batismo, nas celebrações litúrgicas, nos momentos de oração pessoal e comunitário e na formação de lideranças. Ele é assumido como caminho e meta para a comunidade, que se solidariza com todas as situações de morte e injustiça que tocam os seres humanos,

\begin{abstract}
Aqui em Juazeiro do Norte, CE, diocese de Crato, as comunidades eclesiais de base reafirmam sua vocação, no jeito de ser Igreja das primeiras comunidades e também no espírito das missões populares e das casas de caridade do Padre lbiapina, do padre Cícero Romão Batista, do leigo José Lourenço, assim como de tantas mulheres santas como Maria Araújo, irmãos e irmãs que nos precederam nesse caminho de sermos Igreja dos pobres e com os pobres, CEB's romeiras do campo e da cidade, na comunhão com a Mãe Terra e toda a natureza. Aqui, acolhemos e nos solidarizamos com os povos indígenas, ameaçados no seu direito à posse de suas terras ancestrais e todos os dias vítimas de violência e até de assassinato. Também nos impressionou o relato de extermínio de jovens pobres e negros, em várias regiões do nosso país. E nos solidarizamos com a luta e resistência dos quilombolas e do povo lavrador, ameaçados pelos grandes projetos do Capitalismo depredador do ambiente e injusto para com a maioria da humanidade. ${ }^{229}$
\end{abstract}

A missão de seguir a Jesus se funda nesta solidariedade substitutiva com todos aquele/a que sofre, que é perseguido e violentado, com o mundo que sofre na carne e na terra as dores do parto de um Reino possível, mas que se adia pela força da morte. Acreditar nesse mundo possível para as CEB's é crer no Evangelho, crer que com Jesus ele chegou e que no encontro com o outro se pode descobrir formas dar continuidade a missão do próprio Cristo.

${ }^{228}$ Dom Edson Damian, Bispo de São Gabriel da Cachoeira na Homilia na Celebração dos Profetas e Mártires, no 13ํㅡㄹ Encontro Intereclesial de CEB's. Juazeiro do Norte, CE, 10 de janeiro de 2014. ${ }^{229}$ Carta do $13^{\circ}$ Intereclesial das CEB's ao Papa Francisco. 


\title{
4.2.2 \\ A celebração
}

Somos gente nova vivendo a união, somos Povo, semente, uma nova nação. Somos gente nova vivendo o amor, somos comunidade, Povo do Senhor. ${ }^{230}$

A celebração é o momento de encontro da comunidade com Aquele que as convoca para sentar-se à mesa e falar da vida. Ali o povo chora suas dores, implora ajuda, festeja as vitórias, pede perdão, celebra a aliança e sai fortalecido na fé em Deus libertador. O encontro sempre começa invocando a força que reúne o povo, pedindo a ação do Espírito Santo sobre a comunidade (epiclese); a partir daí ela vive a memória de Jesus (anamnese) e unidas ele, se sentem fortes o bastante para seguir caminhando até o próximo encontro. ${ }^{231}$

Quase sempre é Domingo, dia do Senhor. O encontro está marcado numa casa, na capela ou igreja da comunidade, debaixo de uma árvore, ou na praia. Para quem está nas CEB's, isso não importa. O importante é a união, é cada um, cada uma que vai chegando de vagar, em cada rosto Cristo nos acolhe, em cada cumprimento ou abraço se sente que é o senhor quem recebe.

O Espírito vai tecendo laços que nos reúne com Ele, com o Pai e entre nós. Ao ponto da comunidade conscientemente proclamar: "Bendito seja Deus que nos reuniu no amor de Cristo!"232

\begin{abstract}
Deus chama a gente pra um momento novo, de caminhar junto com seu povo. É hora de transformar o que não dá mais; sozinho isolado ninguém é capaz. Por isso vem, entra na roda com a gente também, você é muito importante. Vem! Não é preciso crer que tudo é fácil,há muita força que produz a morte,gerando dor, tristeza e desolação. É necessário unir o cordão. Por isso vem, entra na roda com a gente também, você é muito importante. Vem! A força que hoje faz brotar a vida atua em nós pela tua graça. É Deus quem nos convida pra trabalhar,o amor repartir e as forças juntar. ${ }^{233}$
\end{abstract}

Neste encontro tudo é colocado de forma que se lembre que quem ali está é a comunidade, a preparação é feita de forma partilhada: um prepara o local, o outro faz o roteiro da celebração, outro grupo anima os cantos, uma liderança faz

\footnotetext{
${ }^{230}$ Música de autoria de Zé Vicente, um dos chamados "cantores da caminhada", entoada em todos os Intereclesiais, para muitos um hino das CEB's.

231 BUYST, lone. "Beba da fonte", p. 105.

232 lbid., p. 108.

${ }^{233}$ Deus chama a gente. Canto de entrada das celebrações e encontros de comunidades. CANTA POVO DE DEUS. Cancioneiro das Comunidades, p. 33.
} 
a homilia, e na ausência do padre, outro preside a celebração. É a vida de um povo ministerial.

Na celebração símbolos que ajudam o povo a rezar e a entrar na mística do que é celebrado: o mistério pascal à luz da realidade da comunidade.

Os cantos lembram o compromisso que suscita o encontro verdadeiro com o dono da festa: "Receber a comunhão com este povo sofrido,é fazer a aliança com a causa do oprimido! Celebrando a Eucaristia a vida a gente consome ao lutar pela justiça, acabando com a fome. Pra que o outro seja gente, pra que ele tenha nome". 234

E a ceia se torna gesto de compromisso, de mudança de vida, não é apenas alimento da fé individual, é comum-união é aliança entre a comunidade e Aquele que se dá como comida e bebida. É pacto de corpo e sangue, por isso reforça a unidade da comunidade.

Essa unidade experimentada na Ceia do Senhor, se repete no cotidiano, não com a mesma realidade ontológica, mas recordando esse grande momento. No pão nosso de cada dia, nas festas celebrando a vida: nascimento, casamento, aniversários, batismo e ás vezes até na morte. ${ }^{235}$ Essa cotidianidade da comida e da bebida, a insere também no plano do encontro da comunidade no ressuscitado.

Ali, são sacramentadas ou emolduradas em bênçãos, as refeições que expressam não apenas o desejo, mas também o prazer e a esperança. Os acontecimentos da vida do povo das CEB's são marcados pela festa e pela comida, a influência das raízes indígena e africana, a força da expressão religiosa portuguesa, podem ser facilmente identificadas no modo de festejar das comunidades. Seja na feijoada do mutirão da laje, seja quermesse da festa do padroeiro ou na "confraternização" depois da reunião. "Motumbá Axé! Motumbá Axé! Aquele que é minha força te abençoe, te abençoe!"236

Comer junto cria um "nós", envolve as pessoas, abre a informalidade e por isso fazem-se brincadeiras, combinam-se trabalhos e reuniões. "Joga-se conversa fora". Este momento parece que vai "costurando" a comunidade. E a comunidade canta e agradece: "Benza Deus! Tanta comida na mesa. Abençoa Senhor, esta casa, que beleza!". ${ }^{237}$

\footnotetext{
234 Ibid., p. 100.

${ }^{235} \mathrm{Em}$ algumas regiões do país todo velório é regado a uma boa comida e uma cachaça. Daí a expressão "beber o morto".

${ }^{236}$ Motumbá axé, benção da missa - Reúne teu povo em Quilombo. CANTA POVO DE DEUS. Cancioneiro das Comunidades, p. 194.

${ }^{237}$ Benção dos alimentos. Ibid.. p. 201.
} 
E a cada encontro vai se estruturando uma rede de laços de afeto, de cumplicidade nas lutas da vida, fazendo "comunhão" e construindo unidades. "Vida surge da comunhão, e onde surgem comunhões que tornam a vida possível e a promovem, aí o Espírito de Deus está atuante". 238

\title{
4.3 \\ Dimensão pessoal - 0 Espírito que liberta
}

Um segundo nascimento, a transformação em uma pessoas nova, como já testemunhou Cipriano, ${ }^{239}$ sempre passa por um processo de descoberta da liberdade, bem maior nos dado pelo Espírito. A vitalidade que nos é dada pelo Espírito nos coloca em confronto direto com a falta de liberdade trazida pela pobreza, pela injustiça, pela dor , pela discriminação e o desamor.

A luta pela liberdade é cara as Comunidades de Base, pois estas sabem que diante de um Deus que nos liberta, não se pode mais ficar omisso diante da escravidão, "pois é para liberdade que Cristo nos libertou" (GI 5,1).

\begin{abstract}
Liberdade vem e canta e saúda este novo sol que vem. Canta com alegria o escondido amor que no peito tens. Mira o céu azul, espaço aberto pra te acolher Mira o céu azul, espaço aberto pra te acolher. Liberdade vem e pisa este firme chão de verde ramagem. Canta louvando as flores que ao bailar do vento fazem sua mensagem. Mira estas flores abraço aberto pra te colher. Mira estas flores abraço aberto pra te acolher. Liberdade vem e pousa nesta dura américa triste vendida. Canta com o teu grito nossos filhos mortos e a paz ferida. Mira este lugar desejo aberto pra te acolher. Mira este lugar desejo aberto pra te acolher. Liberdade, liberdade és o desejo que nos faz viver. És o grande sentido de uma vida pronta para morrer. Mira o nosso chão banhado em sangue pra reviver. Mira a nossa américa banhada em morte pra renascer. ${ }^{240}$
\end{abstract}

Muitas são as experiências de libertação, vivida em situações-limite nas CEB's, principalmente considerando que grande parte das comunidades estão nas periferias das cidades ou nas zonas rurais. Poderíamos elencar aqui inúmeras experiências de vida e morte que tocam profundamente a vida dos que estão nas CEB's, mas como queremos falar sobretudo das experiências que testemunhamos, escolhemos falar do processo de libertação vivido pelos pobres, os que sofrem e as mulheres.

238 MOLTMANN, Jürgen., O Espírito da Vida, p. 208.

239 CIPRIANO, A Dontato, III-IV., n. 291. Apud LIÉBAERT, Jaques. Os Padres da Igreja [Séculos IIV], p. 106.

240 A música Liberdade, de cantor da caminhada (como as CEB's chamam seus compositores) Zé Martins, é um hino cantado em todos as CEB's do país e em outros países da America Latina onde possui uma versão em espanhol. 


\subsection{1 \\ Os destinatários do Reino - a libertação dos pobres}

A opção preferencial pelos pobres sempre foi imperativo vivido pelas CEB's, não iremos aqui entrar na discussão histórica do nascimento dessa prerrogativa evangélica na histórica da Igreja. A nós interessa, neste momento refletir como é experienciado pelo destinatário dessa mensagem: os pobres.

Álvaro Barreiro nos lembra, que os cristãos que estão nas CEB's não conhecem nenhuma das formas de triunfalismo, nem sequer têm consciência reflexa da riqueza evangélica de que são portadores. Não Ihes passa pela cabeça, se apresentar como modelos, querem apenas "fazer a vontade" de Deus. ${ }^{241}$

Fazer a vontade de Deus nas CEB's, é trabalhar na construção do Reino, entra aqui a visão teológica veterotestamentária da figura do Rei. O rei é aquele que deve fazer reinar o direito e justiça, a ele pertence a responsabilidade de cuidar dos pobres, das viúvas e das crianças. O fundamento do privilégio dos pobres não se encontra numa concepção idealizada da sua pobreza, mas num ideal da função real. Portanto não se encontra a opção preferencial nas disposições espirituais interiores dos pobres, mas em Deus, na disposição de Deus, na maneira como Ele concebe o exercício de sua realeza em favor dos "débeis e infelizes". 242

Se em Jesus se dá a proclamação do estabelecimento do Reino de Deus, essa proclamação é então sobretudo aos pobres, os oprimidos, para todos os infelizes. A comunidade proclama e anuncia essa fé todas às vezes que se reúne. Ou seja todas as vezes que a comunidade assume a missão - seguimento de Jesus Cristo - ela reafirma que são eles mesmos os destinatários do Reino de Deus.

As comunidades de base entendem que, o Espirito que unge os pobres, para libertar outros pobres, excluídos, marginalizados, escravizados, perseguidos; permanece com eles vai até a cruz de for preciso for.

241 BARREIRO, Álvaro., Comunidades Eclesiais de Base e Evangelização dos Pobres, p. 15. 242 lbid., p. 37. 


\subsection{2 \\ A espiritualidade da cruz}

Ouvir, saber, sentir nos gestos concretos de justiça na comunidade, que há um Rei que irá me resgatar, que irá fazer me devolver a vida que ele mesmo me deu gratuitamente e que me foi retirada pelas estruturas de pecado torna possível o cultivo da esperança. E é a esperança a experiência mais profunda e fecunda que é devolvida ao pobre em uma Comunidade Eclesial de Base. Esperar diante de toda injustiça, diante de todo sofrimento, esperar não por merecimento, mas por justiça, porque Aquele que Reina no mundo que a comunidade já começa a construir, pode e quer resgatar aqueles que dele necessitam.

Onde, pela ressurreição do crucificado, foram rompidas as barreiras contra as quais se despedaçam todas as esperanças humanas, a fé pode e deve alargar-se em esperança. Assim ela se torna $\pi \alpha \rho \rho \eta \sigma \iota \alpha$ (fraqueza, ousadia) $\mu \alpha \kappa \rho \theta u \mu \iota \alpha$ (longanimidade); assim sua esperança se torna paixão pelo possível (Kierkegaard), porque pode agora ser paixão por aquilo que se tornou possível; assim pela esperança de realizar a extensio animi ad magna, como se dizia na Idade Média. [...] A fé une o ser humano a Cristo, a esperança abre essa fé para o vasto futuro de Cristo. Por isso, a esperança é a "companheira inseparável" da fé. 243

Quando o ser humano se despedaça, sua única opção é juntar os cacos da vida e dela fazer um mosaico. Um vitral onde a fé se torna esperança e pela "fraqueza - ousadia" ele é capaz de ver sua beleza onde muitos só enxergam o lixo.

Na experiência comunitária, os empobrecidos, os excluídos, os que sofrem, contemplam vitral de suas vidas e podem dizer: É isso que somos! E Deus está aqui! E se um dia a obra deste Deus foi quebrada, o que temos agora, em nossa pobreza, é nada! Mas não o nihil (o vazio). É o nada do caos das nossas angústias, dos sonhos não realizados, das experiências vividas, ora na noite escura, ora sem ver o sol escondido pela sombra da morte. É o nada da solidão, ausência de alguém que esperamos. Solidão da doença, dor impossível de se compartilhar com o outro. Dor da perda do filho ou filha amada. Solidão do abandono na Cruz.

Quando no caos, na solidão, nos identificamos com o Cristo na cruz, somos capazes de nele descobrir a certeza de que não estamos sozinhos. Que na vida ou na morte estamos nas mãos daquele que nos criou. Que Ele não abandona sua obra mesmo que aos olhos humanos esta seja feia e desfigurada. Descobrimos então que Nele esperamos, Nele eu cremos!

${ }^{243}$ MOLTMANN, Jürgen., Teologia da Esperança, p. 34. 
Então com o Cristo crucificado há a possiblidade de ressuscitar, de se resiliar diante de toda a desesperança. A comunidade então reconhece no Cristo crucificado o seu futuro.

Ela não vê na ressurreição de Jesus Cristo a eternidade do céu na terra, mas o futuro da própria terra na qual está plantada sua cruz. Em Cristo ela reconhece o futuro da humanidade, pela qual ele morreu. Por isso, para ela, a cruz é a esperança da terra. [...] aquele que assim espera nunca se conformará com as leis e obrigatoriedades desta terra, nem com a inevitabilidade da morte, nem os males que geram outros males. Para esse indivíduo, a ressurreição de Cristo não é somente consolo em meio a uma vida ameaçada e condenada à morte, mas também a contradição criada por Deus contra o sofrimento e a morte, contra a humilhação e a ofensa, contra a maldade do mal. ${ }^{244}$

Se aquele ou aquela que sofre, o abandono do Cristo na cruz nos aproxima de sua humanidade, sua ressureição aponta o nosso futuro. Não o futuro distante, do céu além da vida, mas o futuro na terra nossa capacidade de fazer novas todas às coisas. De entender que nossa história tal qual o madeiro da cruz, está fincada nesta terra.

E é por ela, pela cruz, por toda injustiça e por toda esperança que ela representa que nós não podemos aceitar as mazelas do mal neste mundo. Sabemos que ele existe e sempre existirá, pois é fruto da nossa limitação humana, mas não podemos aceitar que em um mundo, onde o Amor se fez carne por nós, ele (o mal) seja uma opção consciente de grande parte dos seres humanos.

A comunidade não pode aceitar que os ramos da morte sejam maiores que os galhos da vida. Por isso a esperança não é uma espera acomodada pelo salvador que virá. Ela é uma luta constante para que todos possam experimentar, já aqui, as sementes da salvação.

Mesmo aquele ou aquela que viveu aprisionada pelas correntes da escravidão, fruto do mal social é capaz de, pela cruz de Cristo, encontrar vida nova, como exemplifica o Papa Bento XVI na Carta Encílica Spe Salvi, ao falar da vida de Josefina Bakhita, uma africana canonizada pelo Papa João Paulo II.

\begin{abstract}
Não é difícil notar como a experiência da humilde escrava africana Bakhita foi também a experiência de muitas pessoas maltratadas e condenadas à escravidão no tempo do cristianismo nascente. O cristianismo não tinha trazido uma mensagem sócio-revolucionária semelhante à de Espártaco que tinha fracassado após lutas cruentas. Jesus não era Espártaco, não era um guerreiro em luta por uma libertação política, como Barrabás ou Bar-Kochba. Aquilo que Jesus - Ele mesmo morto na cruz - tinha trazido era algo de totalmente distinto: o encontro com o Senhor de todos os senhores, o encontro com o Deus vivo e, deste modo, o encontro com uma esperança que era mais forte do que os sofrimentos da escravatura e, por isso mesmo, transformava a partir de dentro a vida e o mundo. ${ }^{245}$
\end{abstract}

\footnotetext{
244 Ibid., p. 36.

245 BENTO XVI., Spe Salvi, n.4.
} 
A transformação a partir de dentro, é isso que aquele ou aquela, que sofre ou sofreu nas tramas da morte experimenta no encontro com o Cristo morto e ressuscitado. ${ }^{246}$ Esta transformação é uma dinâmica de espera e abertura. Nesta espera, o Espírito é o Paráclito, é o consolador, é Aquele que nos abraça diante da cruz, ensina a entender os processos de instauração do Reino. Ele acompanha, dá força e as vezes mostra o caminho, que é sempre feito em comunidade, junto do outro, da outra, pois este Reino é primeiro dos pobres, mas o Reino é destinado à todos.

\title{
4.3.3 O Espírito e a libertação das mulheres
}

A comunidade pode ser muitas vezes o único apoio para tantas mulheres empobrecidas, violentadas e marginalizadas. Na partilha da Palavra elas vão descobrindo possibilidade de discussão das suas histórias de vida e das suas vivências sociais resultando numa conscientização coletiva que não só as liberta, mas as aproxima a partir da identificação das dores vivem e dos processos de discriminação, injustiças, e assimetrias às quais muitas são submetidas.

\begin{abstract}
Para estas mulheres as CEB's são espaços simbólico-afetivos de reinterpretação de suas próprias histórias, onde pela troca de narrativas elas desmitologizam os espaços: familiar e íntimo como espaços idílicos, aparentemente despovoados de coação e violência, possibilitando-lhes uma reapreciação de sua posição social e, em última análise, uma possiblidade de ressocialização e reaprendizagem do seu papel no mundo social circundante. ${ }^{247}$
\end{abstract}

\footnotetext{
${ }^{246}$ Quando criança eu meus primos estudávamos numa escolinha que funcionava na CEB's Santo Expedito, Diocese de Leopoldina, tínhamos 05 ou 06 anos e tirávamos o nosso cochilo, nossa hora do descanso deitados nos bancos da capela. Atrás do altar ficava a cruz onde o Cristo com um olhar manso e sereno parecia quase dormir em meio a todas as feridas e pregos. Aquele olhar ficou gravado na minha lembrança como uma fotografia antiga que vez por outra insisto em visitar. Porém, me lembro ainda mais da outra cruz, a cruz que não tinha Cristo, a cruz moldada pelos artistas, os pedreiros da comunidade. Eles usaram tijolinhos deitados para formar a cruz e, pelos buracos dos tijolos, a luz da tarde entrava na capela. Era aconchegante nas tardes de outono, sentir o calor que vinha daquela cruz. Acho que foi a experiência do encontro destas duas cruzes, com a minha cruz, mais a vida da minha comunidade, que me ajudaram a me encontrar com Jesus Cristo Vivo. Eram tempos difíceis, como ainda o são para qualquer criança pobre, negra, sem pai nem mãe, que vive nas nossas favelas. Muitas ainda são as correntes que escravizam nosso povo. Porém há sempre a possibilidade de, em meio às amarras do mal, conhecer Jesus Cristo e redescobrir a vida a partir do seu projeto de amor.

${ }^{247}$ NEVES, Sofia; NOGUERIA, Conceição. "A psicologia feminista e a violência contra as mulheres na intimidade", p. 56.
} 
Ao participarem das CEB's, as mulheres beneficiam a sí próprias, através da participação e expressão da sua vida, ao emitir sua palavra e recuperar sua voz. Elas passam da condição de objeto sem voz nem vez, a sujeito. ${ }^{248}$

A recuperação da voz possibilita o aumento da autoestima, permite adquirir confiança, autonomia, se recobra a dignidade e seu lugar na família, na comunidade e na sociedade. Essa transformação acontece na dimensão pessoal de sua experiência de vida: de mulheres tímidas, acanhadas, tornam-se pessoas corajosas, lutadoras; pessoas antes submissas, assumem sua autonomia; de pessoas dependentes, tornam-se alguém que luta pela liberdade. ${ }^{249}$

Pode se compreender este processo de transformação a partir de uma perspectiva sociológica, psicológica e até antropológica. Mas não estamos aqui falando de processos terapêuticos, mas sim do encontro com uma verdade que liberta. O um encontro com um Deus amoroso e uma comunidade que inclui, aceita e traz para seu meio, aquelas que sentem a parte. E podem falar deste encontro com sua própria voz. ${ }^{250}$

Encontro que, no trabalho com as comunidades tivemos, muitas vezes a alegria de testemunhar, ver e ouvir o apelo de mulheres que o momento de abandono, encontravam na comunidade a coragem para se reconstruir e se levantar. Que confiam na ação do Espirito que geme, chora e intercede por cada uma, sonda o mais íntimo da realidade da sua dor e exprime sua intercessão com gemidos inefáveis $(\mathrm{Rm} 8,26)$.

Este mesmo Espírito não só consola e empodera essas mulheres, mas chama a comunidade a dar uma resposta concreta à vida que alí se coloca aberta ao novo e as possibilidades que o Reino encerra.

Essa interação entre a fé da comunidade e a realidade destas mulheres vai se dar das mais diferenciadas formas: nas paraliturgias, onde o simbólico abre espaço para estética da vida e da história; nas lutas sociais, onde a busca por melhores condições de vida, coloca na mesma linha de frente, homens e

\footnotetext{
248 PERALIAS, Isabel Ortega. Participação e autonomia das mulheres nas Comunidades Eclesiais de Base (CEB's), p. 45.

249 lbid.

${ }^{250}$ A teóloga mexicana, Maria Pilar Aquino, em "A teologia, a Igreja e a mulher na América Latina", publicado em 1997, cita a Teologia da Libertação como fator que, em grande medida, abriu às mulheres a possibilidade de fazerem parte da construção do conhecimento e do discurso teológico a partir de suas próprias experiências. Como afirma, as mulheres se reapropriaram de "um direito sequestrado" (ou seja, "o de refletir a partir de sua própria condição, situação e consciência como mulheres sobre a experiência peculiar da revelação de Deus como ela acontece em sua vida") e passaram a reconhecer-se como "sujeitos de pleno direito". A crescente incorporação das mulheres nos movimentos sociais populares, muitos deles de caráter feminista, além da sua já conhecida participação em vários campos da ação pastoral da Igreja, fizeram com que elas passassem a ser sujeitos da mudança e não mais apenas espectadoras. AQUINO, Maria Pilar. A teologia, a lgreja e a mulher na América Latina, pp. 5-6, 11-12, 16.
} 
mulheres; na mediação de conflitos familiares, já que as lideranças são requisitadas a todo momento pela comunidade a fim de intervir em busca da paz; na pregação da palavra, a proclamação do Evangelho concede um certo "status quo" àquela que o realiza.

Nas CEB's, com o instrumental dado pela Teologia Feminista, a mulher se liberta dos velhos paradigmas que a culpabilizavam por suas próprias tragédias. Redescobre-se enquanto pessoa, na sua dimensão de imanência, se auto pertencendo, se auto definindo, conquistando sua perseidade, vivenciando um processo de empoderamento e se redescobrindo como "imagem de Deus". Num processo dialógico, onde o outro passa a não ser uma ameaça, mas uma nova possibilidade de encontro, de transcendência.

\title{
4.4 \\ Os desafios de hoje
}

Em 2010 a CNBB já levantava, no Documento 92 os principais desafios para as CEB's diante de um mundo globalizado:

\begin{abstract}
Com as grandes mudanças que estão acontecendo no mundo inteiro e em nosso país, as CEB's enfrentam hoje novos desafi os: numa sociedade globalizada e urbanizada, como viver em comunidade? Nascidas num contexto ainda em grande parte rural, serão capazes de se adaptar aos centros urbanos, que têm um ritmo de vida diferente e são caracterizados por uma realidade plural? Dentro desse contexto, há outro desafio: como transmitir às novas gerações as experiências e valores das gerações anteriores, inclusive a fé e o modo de vivê-la? Só uma Igreja com diferentes jeitos de viver a mesma Fé será capaz de dialogar relevantemente com a sociedade contemporânea. ${ }^{251}$
\end{abstract}

São os muitos os desafios para CEB's nos dias de hoje, assim como o são para toda a Igreja, no entanto existem alguns cujas temáticas foram abordadas tanto pelas próprias CEB's em seus intereclesiais, como veem sendo preocupação do Magistério de toda Igreja. Elencamos aqui alguns destes desafios.

${ }^{251}$ CNBB., Mensagem do Povo de Deus sobre as Comunidades Elesiais de Base, p. 12. 


\title{
4.4.1 \\ O que e como são as CEB's hoje
}

Se o desafio de ontem era provar sua identidade eclesial o de hoje talvez seja redescobrir essa identidade dentro da nova reconfiguração mundial.

O Documento 92 da CNBB nos chama atenção para importância das CEB's na história da Igreja como dando continuidade a experiência das primeiras comunidades cristãs e afirma:

\begin{abstract}
Elas representam uma maneira de ser Igreja, de ser comunidade, de fraternidade, inspirada na mais legítima e antiga tradição eclesial. Teologicamente são, hoje, uma experiência eclesial amadurecida, uma ação do Espírito no horizonte das urgências de nosso tempo. ${ }^{252}$
\end{abstract}

No entanto as CEB's têm hoje o desafio de redescobrir no meio de uma nova conjuntura nacional sua identidade como comunidade. Já nos anos 80 , Frei Betto já elencava como desafio a questão da identidade das CEB's, a necessidade no "tecido das contradições da conjuntura, descobrir como ser coerente com seus princípios evangélicos e se colocar ao lado dos oprimidos". 253

Essa redescoberta da identidade encontra suas dificuldades numa via de mão dupla: dentro da dinâmica das próprias comunidades que muitas vezes não identificam mais como CEB's e de fora dela quando o clero não identifica vida paroquial o surgimento de novas comunidades eclesiais de base.

Salvo exceções inspiradas e frutuosas, expressivas parcelas dos grupos e pessoas que se reconhecem como CEB's não conseguem alcançar fortes laços orgânicos e organizativos, como fazendo parte de sua rotina, do seu dia-a-dia, especialmente quando se trata de relacionar-se com seus parceiros de outras regiões. Muito menos em relação a outros segmentos da Igreja na Base. Isto até se passa bem, no âmbito das instâncias de coordenação, mas será que basta? E o quê dizer em relação aos laços orgânicos com parceiros de outras igrejas e dos movimentos populares? Muitas de nossas CEB's até cumprem bem atividades importantes, mas em geral circunscritas à sua área específica de atuação, com poucas ou nulas conexões com outras CEB's e outros parceiros da Igreja na Base, seja no âmbito regional, seja nos planos nacional e internacional. Algo semelhante também se dá no seu agir social: laços muito frouxos com os movimentos e lutas sociais, sempre ressalvadas as exceções de reconhecida qualidade. ${ }^{254}$

Nos anos 90 as CEB's tiveram como desafio, o antagonismo a vivência de usa espiritualidade e a espiritualidade da RCC (Renovação Carismática Católica), esse antagonismo que gerou o esvaziamento de muitas CEB's, também

252 lbid., p. 9.

253 BETTO, Frei., O que é Comunidade Eclesial de Base, p. 24.

254 CALADO, Alder. "CEB's: Desafios e Perspectivas de Enfrentamento", p. 3. 
comtribuiu para o fortalecimento de uma estrutura paroquial mais centralizada na figura clerical e uma relativização do engajamento social.

A tal coerência, que nos chamava a atenção Frei Betto, foi sendo perdida aos poucos diante do convite a uma espiritualidade mais individualizada e menos comunitária.

No entanto, há também hoje, a experiência daquelas comunidades que vivem fortemente as características das mesmas e que por medo ou falta de conhecimento eclesiológico não se reconhecem como CEB's. Ou do próprio clero que não reconherece esta identidade em suas comunidades.

A própria Arquidiocese de S. Sebastião do Rio de Janeiro, ao longo de todo o processo de elaboração do $11^{\circ}$ Plano de Pastoral, chegou à conclusão de que, para ser fiel ao Senhor da Missão e aos desafios do tempo de hoje, precisa ser: "Uma Igreja que anuncia e reanuncia Jesus Cristo, numa rede de comunidades, serviços e ministérios, em permanente estado de missão, a serviço da vida em todas as suas instâncias".

A Arquidiocese que não reconheceu e que teve inúmeras dificuldades eclesiais com as CEB's do país convida às comunidades a viverem a opção preferencial aos pobres,

\begin{abstract}
O serviço testemunhal à vida, de modo especial à vida fragilizada e ameaçada, é a mais forte atitude de diálogo que o discípulo missionário pode e deve estabelecer com uma realidade que sente o peso da cultura da morte. Na solidariedade de uma igreja samaritana, o discípulo missionário vive o anúncio de um mundo diferente que, acima de tudo, por amar a vida, convoca à comunhão efetiva entre todos os seres vivos. ${ }^{255}$
\end{abstract}

A palavra comunidade aparece incontáveis vezes no plano de Pastoral de Conjunto da Arquidiocese do Rio de Janeiro. Não estaria a Igreja do Rio de Janeiro indiretamente fazendo um convite a viver o " jeito de ser lgreja" das CEB's?

\title{
4.4.2
}

\section{A Linguagem e a comunicação nas CEB's hoje}

A experiência do Espírito nas CEB's está fortemente vinculada ao encontro com o outro/a como vimos no capítulo anterior. É no encontro com o outro que se dá a costura da vida, a troca de saberes, a força de enfrentar os desafios e coragem para promover a justiça.

${ }^{255}$ ARQUIDIOCESE DO RIO DE JANEIRO. $11^{\circ}$ Plano Pastoral de Conjunto, n.136. 
Nas primeiras décadas, este diálogo era possibilitado pela cultura comum, pelo nivelamento social e pelos sonhos partilhados. Era, por assim dizer, mais fácil encontrar uma linguagem comum a toda comunidade. Por exemplo, numa comunidade rural, a foice, a enxada, a semente, eram símbolos que na liturgia representavam o trabalho e a vida do Povo. Havia então uma comunicação que possibilitava a identificação entre fé e vida.

Vivemos hoje em um mundo plural e globalizado. A mobilidade humana cresceu. Hoje em uma comunidade ribeirinha, já não se tem mais só o pescador ou a artesã. Em uma comunidade rural, não se trabalha só na terra. Há quem more na zona rural e trabalhe na cidade. Sem contar a problemática das grandes cidades, onde as comunidades são compostas de pessoas de diferentes estados, com culturas diversas, com vivências de catolicismo totalmente diferentes umas das outras.

No Rio de Janeiro, por exemplo, acompanhei a caminhada das poucas CEB's, que aqui existem, clandestinamente até bem pouco tempo, na Zona Oeste, em Vargem Grande e em Curicica. Essas comunidades, como quase todas as de periferias das grandes cidades é composta de migrantes. Numa reunião com um grupo de 15 pessoas, você consegue ter pelo menos cinco estados diferentes. Isso sem contar as diferenças étnicas, os diferentes graus de formação, e as estruturas familiares mais diversas.

Como promover o encontro com o outro, com Deus e consigo mesmo para que se possa criar comunidade, mesmo na diversidade?

Que natureza deveria ter hoje esta linguagem para seguir como catalizadora desta experiência da Ruah? Será que o tríplice movimento: êxodo, compromisso e proximidade apresentado por Faustino Teixeira ou a ordem das dimensões aqui apresentada: geracional, comunitária e pessoal, não devem ser invertidas? Será que antes de chamar a comunidade a ser povo, primeiro não teríamos que resgatar a pessoa?

Talvez as comunidades possam buscar junto ao movimento pentecostal algumas experiências que as ajudem a encontrar o que é capaz de aproximar as pessoas a partir do que é comum a todo ser humano. 


\subsection{3 \\ A opção preferencial pelos pobres hoje}

A questão da opção pelos pobres, ainda é uma temática a ser aprofundada com mais atenção e abertura nas CEB's. Hoje, esta categoria abrange uma gama maior de pessoas vivendo à margem da estrutura social. A dimensão da pobreza passa hoje por camadas ainda mais profundas do tecido social. À multidão dos que nada tem, juntam-se os transexuais, os migrantes, os sem-terra, os exilados e tantos outros. Como falar de opção, se muitos descartados nem se veem como pobres?

Os 72 bispos presentes no $13^{\circ}$ intereclesial, em uma mensagem às CEB's e ao povo, escreveram:

Muito nos sensibilizaram os gritos dos excluídos que ecoaram neste $13^{\circ}$ intereclesial: gritos de mulheres e jovens que sofrem com a violência e de tantas pessoas que sofrem as consequências do agronegócio, do desmatamento, da construção de hidrelétricas, da mineração, das obras da copa do mundo, da seca prolongada no Nordeste, do tráfico humano, do trabalho escravo, das drogas, da falta de planejamento urbano que beneficie os bairros pobres; de um atendimento digno para a saúde (...).

Também no 13ํㅡㄴ Intereclesial a Pastoral da Juventude levantou a questão do extermínio dos jovens negros pelo país a fora.

A Igreja do Brasil em suas Diretrizes Gerais nos lembra que a opção pelos pobre deve ser vivida em gestos concretos:

O discípulo missionário reconhece que seu sonho por vida eterna leva-o a ser, já
nesta vida, parceiro da vida e vida em plenitude. Daí "ratifi car e potencializar a
opção preferencial pelos pobres", "implícita à fé cristológica naquele Deus que se
fez pobre por nós, para nos enriquecer com sua pobreza", que deverá "atravessar
todas as suas estruturas e prioridades pastorais" 88 manifestando-se "em opções e
gestos concretos". ${ }^{256}$

Passados aproximadamente 32 anos apos a primeira Instrução sobre Teologia da Libertação, o atual papa Francisco, na Exortação apostólica "Evangelii Gaudium", de 24 de novembro de 2013, no encerramento do Ano da Fé, afirma que as duas grandes questões fundamentais, neste momento da história, que irão determinar o futuro da humanidade são, respectivamente, a inclusão social dos pobres e a questão da paz e do diálogo social. ${ }^{257}$

Reafirma a opção pelos pobres sem deixar nenhuma dúvida:

${ }^{256}$ CNBB. Diretrizes Gerais da Ação Evangelizadora da Igreja no Brasil, p. 63

257 EG, n. 185. 
Não devem subsistir dúvidas nem explicações que debilitem esta mensagem claríssima. Hoje e sempre, "os pobres são os destinatários privilegiados do Evangelho", e a evangelização dirigida gratuitamente a eles é sinal do Reino que Jesus veio trazer. Há que afirmar sem rodeios que existe um vínculo indissolúvel entre a nossa fé e os pobres. Não os deixemos jamais sozinhos!258

Em vários dos seus discursos, o Papa Francisco retoma o tema da opção pelos pobres, diz "querer uma Igreja pobre para os pobres", convida a Igreja a sair de sí mesma e ao encontro do outro que dela necessita.

Saiamos, saiamos para oferecer a todos a vida de Jesus Cristo! Repito aqui, para toda a Igreja, aquilo que muitas vezes disse aos sacerdotes e aos leigos de Buenos Aires: prefiro uma Igreja acidentada, ferida e enlameada por ter saído pelas estradas, a uma Igreja enferma pelo fechamento e a comodidade de se agarrar às próprias seguranças. Não quero uma Igreja preocupada com ser o centro, e que acaba presa num emaranhado de obsessões e procedimentos. Se alguma coisa nos deve santamente inquietar e preocupar a nossa consciência é que haja tantos irmãos nossos que vivem sem a força, a luz e a consolação da amizade com Jesus Cristo, sem uma comunidade de fé que os acolha, sem um horizonte de sentido e de vida. Mais do que o temor de falhar, espero que nos mova o medo de nos encerrarmos nas estruturas que nos dão uma falsa protecção, nas normas que nos transformam em juízes implacáveis, nos hábitos em que nos sentimos tranquilos, enquanto lá fora há uma multidão faminta e Jesus repete-nos sem cessar: «Dai-lhes vós mesmos de comer» (Mc 6, 37).259

É certo que não existe uma nova "categoria de pobres" para a Igreja , o que existe são consequências devastadoras que nascem da pobreza, passam pela exploração, discriminação, corrupção, intolerância religiosa e tantas outras mazelas sofridas pelo nosso povo.

A opção preferencial pelos pobres continua no núcleo de uma espiritualidade libertadora, nos pedindo a vida, o croação.

No núcleo da opção preferencial pelo pobre háum elemento espiritual de experiência do amor gratuito de Deus. O rechaço à injustiça e à opressão que ela implica está ancorada em nossa fé no Deus da vida. Não surpreende, portanto, que essa opção tenha sido rubricada com sangue daqueles que ,como dizia Dom Romero, morreram com o sinal do mártrírio. ${ }^{260}$

Hoje as comunidades se perguntam: quem são os pobres? Onde estes estão? Do que adianta libertar o pobre, se amanhã pode não haver mais condições de existência neste planeta, devido a exploração e o desrespeito à criação?

O Papa lembra que são os pobres os que mais sofrem com a degradação ambiental.

O urgente desafio de proteger a nossa casa comum inclui a preocupação de unir toda a família humana na busca de um desenvolvimento sustentável e integral, pois sabemos que as coisas podem mudar. O Criador não nos abandona, nunca recua

\footnotetext{
258 EG, n.48.

259 EG. 49

260 MÜLLER, Gerhard Ludwig; GUTIÉRREZ, Gustavo. Ao lado dos pobres, p. 80
} 
no seu projecto de amor, nem Se arrepende de nos ter criado. A humanidade possui ainda a capacidade de colaborar na construção da nossa casa comum. Desejo agradecer, encorajar e manifestar apreço a quantos, nos mais variados sectores da actividade humana, estão a trabalhar para garantir a protecção da casa que partilhamos. Uma especial gratidão é devida àqueles que lutam, com vigor, por resolver as dramáticas consequências da degradação ambiental na vida dos mais pobres do mundo. Os jovens exigem de nós uma mudança; interrogam-se como se pode pretender construir um futuro melhor, sem pensar na crise do meio ambiente e nos sofrimentos dos excluídos. ${ }^{261}$

Nosso planeta tornou-se, por nossas mãos, um oprimido, um escreavizado que precisa ser libertado e protegido da nossa ganância.

\subsection{4 \\ São ou não as CEB's uma Igreja pneumatológica}

Nossa reflexão, a partir do pensamento de Moltmann, nos leva então a afirmar que toda verdadeira experiência de vida é experiência de Deus. Ou seja, toda experiência cotidiana resguarda um fundo transcendente; é como se "vida" fosse então o outro nome de "Deus", assim, celebrar a vida é celebrar a Deus. É claro que não fazemos a experiência do "todo" de Deus porque Ele é espírito absolutamente transcendente em relação ao mundo, mas o experimentamos na sua transcendência imanente. ${ }^{262}$ Ou seja, na sua presença em nós, e no mundo criado. ${ }^{263}$

"O Espírito de Deus enche a terra, a tudo dá consistência e tem conhecimento de tudo que se diz" (Sb 1,7). Deus está em tudo e em todos, vivificando e transformando o mundo.

A imanência de Deus em todas as coisas vem sendo objeto da reflexão teológica no tempo presente, e cunhou-se a expressão "panenteísmo" para dar conta dessa presença de Deus no cosmos e do cosmos em Deus. Distintamente do "panteísmo", que não resguarda a diferença entre Deus e o mundo, a nova perspectiva ressalta sua mútua interpenetração. ${ }^{264}$

${ }^{261}$ FRANCISCO., Carta Encíclica Laudato Si', n. 13.

262 O conceito de transcendência imanente é proposto por Moltmann como uma alternativa a estreita referência à autoconsciência moderna. Deus é absoluto, o mundo não é Deus, mas Deus está no mundo, compenetrando-o e vivificando-o por dentro. "Só o Espírito pode ser mais íntimo que o meu íntimo..., só o Espírito pode ser a tal ponto imanente ao homem e ao mundo, permanecendo inviolável e imutável em sua transcendência absoluta".

263 MOLTMANN, Jürgen., O Espírito da Vida., p. 43-44

264 A expressão grega "panenteísmo" significa a conjunção de pan (tudo), en (em), e theós (Deus). Ou seja: tudo em Deus. Algo distinto de "panteísmo": pan (tudo) e theós (Deus). TEIXEIRA, Faustino., "O irrevogável desafio do pluralismo religioso, p. 28. 
Tudo não é Deus. Mas Deus está em tudo e tudo está em Deus, por causa da criação, pela qual Deus deixa sua marca registrada e garante sua presença permanente na criatura (Providência). A criatura sempre depende de Deus e o carrega dentro de si. Deus e mundo são diferentes. Um não é o outro. Mas não estão separados ou fechados. Estão abertos um ao outro. Encontram-se mutuamente implicados. Se são diferentes é para poderem se comunicar e estarem unidos pela comunhão e mútua presença. ${ }^{265}$

O teólogo e cientista da religião, Faustino Teixeira, lembra que esta abordagem teológica, a capacidade de perceber a presença do Mistério em todas as coisas, é muito comum entre os místicos. Mestre Eckhart fala do Deus que "resplandece em todas as coisas" e Teilhard de Chardin, do Deus tangível que, como uma atmosfera, envolve o ser humano por todos os lados. O monge e poeta nicaraguense, Ernesto Cardenal, desvenda na natureza o amor "perceptível e materializado de Deus". Ela guarda em si o "esplendor de sua beleza". Na tradição sufi, o místico Ibn 'Arabi desvenda nas diversas formas que o mundo encerra a presença da "linguagem de Deus". ${ }^{266}$

A possibilidade de reconhecer Deus em todas as coisas e todas as coisas em Deus fundamenta-se teologicamente na compreensão do Espírito de Deus como a força da criação e como a fonte de vida. A experiência do Espírito de Deus é sempre a consciência do "espírito da comunidade", da "divindade comunitária, que une Eu, Tu e Nós. ${ }^{267} \mathrm{~A}$ comunhão que faz com que eu reconheça na experiência do outro a divina presença, que gera laços que duram gerações, que suscita compromisso com o outro e com o mundo criado.

Em tempos pós-modernos, em meio a inúmeras novas experiências religiosas, as CEB's seguem atuais. No mundo globalizado e globalizante, mercantilizado e mercantilizante, somos induzidos a esquecer a memória, renunciar a cruz e desacreditar da utopia do Reino. Entretanto, as CEB's entendem que o resgate permanente da história, o cultivo da espiritualidade libertadora e o fortalecimento do sonho de uma sociedade mais justa e igualitária são condições indispensáveis para seguir a caminhada.

Porém, é preciso criar novas comunidades eclesiais a partir dos novos excluídos. Em meio a tantas dificuldades, dores, sofrimentos, frustrações, violência, exclusão e morte é essencial sermos, como afirma dom Pedro Casaldáliga, "esperançados e esperançadores". Elas têm importante missão nesse mundo. Seu projeto e método prosseguem tendo um papel fundamental na luta pela libertação dos pobres e excluídos.

\footnotetext{
265 BOFF, Leonardo., Ecologia, p. 236.

266 TEIXEIRA, Faustino., "O irrevogável desafio do pluralismo religioso", p. 29.

267 MOLTMANN, Jürgen., O Espírito da Vida, p. 44-45.
} 
Esse jeito de ser Igreja não perderá sua importância enquanto houver fome, miséria, opressão, exclusão, injustiça, corrupção, agressão à dignidade, depredação do meio ambiente... Olhar para essas situações não é fácil, nem mesmo para a Igreja. É preciso um olhar profético como o de Dom Helder Câmara que logo nas primeiras semanas na Arquidiocese de Olinda e Recife, voltou seus olhos para a situação gritante de miséria que o povo fazia questão de ecoar. Vozes do desespero que ressoavam aos ouvidos e ao coração do arcebispo. Então comentou o Arcebispo:

\begin{abstract}
Minha gente é feia? Tem é fome.[...] Pra entender por que cai tanto mocambo, é preciso ter presente que eles são construídos sobre mangues que têm marés, que enchem e esvaziam, levando consigo na subida e na descida, os navios (ou barcos, que não chegam a ser navios) negreiros onde mora o meu povo. [...] Onde estão os teólogos para mergulhar as mãos em realidades assim?268
\end{abstract}

Esse olhar só é possível se a Igreja se deixa guiar pelo Espírito, que possibilita experiências como as da CEB's em seu seio. Que impulsiona novas correntezas, que faz surgir novos sujeitos eclesiais, que transforma o sentir Igreja de que vive esta nova realidade, que tudo movimenta para que a Igreja seja sinal da ação salvífico de Deus no mundo.

E se a Igreja é o Corpo composta pelos membros que somos todos nós, cada experiência de transformação pessoal, vivida nas CEB's, cada vitória alcançada na luta pela justiça, cada nova consciência que se abre à necessidade da transformação do mundo, é mais um passo em direção a esse olhar profético tão necessário à Igreja de Jesus Cristo.

Longe de ser a mais perfeita, mas numa utopia e vivência real do Reino, as CEB's nos mostram que é preciso uma experiência pessoal com o Espírito de Deus, que nos leve ao outro, mesmo diante das limitações, das contradições humanas, das diferenças, das liberdades; é preciso uma vontade, um desejo de "estar junto".

Uma unidade primordial que é suscitada nas experiências de vida e que nos fazem querer precisar do outro/a ao nosso lado, uma necessidade de "ir", de atravessar as águas que circundam a ilha da pessoa que cada um de nós é, em busca de algo/alguém que nos faça encontrar quem somos.

Esse desejo de transcendência, de travessia, necessita de um consentimento da minha liberdade, da pessoa na sua inteireza, que na dimensão

268 CAMARA, Dom Helder. Carta Circular para a Família Mecejanense. Apud LEÃO, Jordana Gonçalves. Fragmentos de um 'diário', p. 46. 
pessoal da experiência do Espírito de Deus, opta por pelo encontro com o outro, opção esta que se funda no encontro pessoal que se tem com Jesus Cristo Vivo. 


\section{5 \\ Conclusão}

Muito provavelmente não há estudos sociológicos e mesmos eclesiolológicos que comprovem que as experiências de catequese popular de Barra do Pirai, do Movimento de Natal com a experiência pastoral de Nísia Floresta e do Movimento de Educação de Base, do Movimento por um Mundo Melhor, da Ação Católica Brasileira e dos Planos de Pastoral da CNBB, juntamente com o Concílio Vaticano II, tenham tido uma ação direta no nascimento das CEB's.

Porém se analisarmos bem, quase nunca podemos apontar com exatidão a raiz de um movimento, uma ação ou até mesmo de uma transformação na Igreja. O Espirito de Deus nunca age a partir de uma só pessoa, de um só lugar, de uma única ação. O Espírito é vento que passa por muitos, que espalha a vontade de Deus nas mais variadas formas, até que as pessoas se encontrem, se unam e o consenso dos fiéis dê forma ao sonho de Deus. Surgem aqui e ali, alguns protagonistas, mas estes nada mais são do que pontos de encontro dos caminhos do Reino.

As experiências que elencamos como base para o nascimento das CEB's, se tornaram experiências históricas. Vividas em várias regiões, suscitaram naqueles/as que as viveram uma nova leitura da lgreja, da sociedade e até mesmo de suas vidas, pois estas mesmas mudam o estatuto laical no que diz respeito à sua identidade não só na Igreja, mas também no Reino de Deus.

É preciso compreender que a força destas experiências não está apenas no seu poder institucional, mas em sua capacidade de mobilizar pessoas, de engendrar projetos que tiveram influências sobre a vida cotidiana destas mesmas pessoas.

As nascentes das CEB's, por sua vez, vivem no seio da instituição, buscando suas próprias bases teológicas e filosóficas, retirando do chão da Bíblia sua cor, sua identidade - a Igreja dos Pobres.

Cada nascente foi dando sua colaboração para a formação das CEB's: ajudando a pensar e sentir a sociedade a partir da fé, tentando entender o lugar do cristão na história e descobrindo que não existem duas histórias, mas apenas uma e nela você é o coadjuvante; capacitado para proclamar o evangelho, e a 
ser sinal deste na vida de outros; dando voz e vez às mulheres, àquelas cujo trabalho silencioso sustentou e ainda sustenta a caminhada da lgreja; ensinando a ler e escrever, fazendo uso de uma pedagogia que não considera quem aprende como uma tábua rasa; saindo pelo país afora implantando o sonho da unidade, capacitando homens e mulheres para viver um novo jeito de ser Igreja.

O ser humano na sua integralidade é possuído pela força de Deus, porque, em última instância, essa força de Deus é o próprio Deus. Ele é o campo onde atuam as forças da morte (a carne) e as forças da vida (o Espírito), onde há concretamente a possibilidade de vivermos no Espírito. Nosso corpo é o lugar onde habita o Espírito, onde experimentamos o arrebatamento da força do Senhor, onde podemos optar pelo martírio ou dar espaço para o processo de transformação e ressurreição na dinâmica histórica da vida.

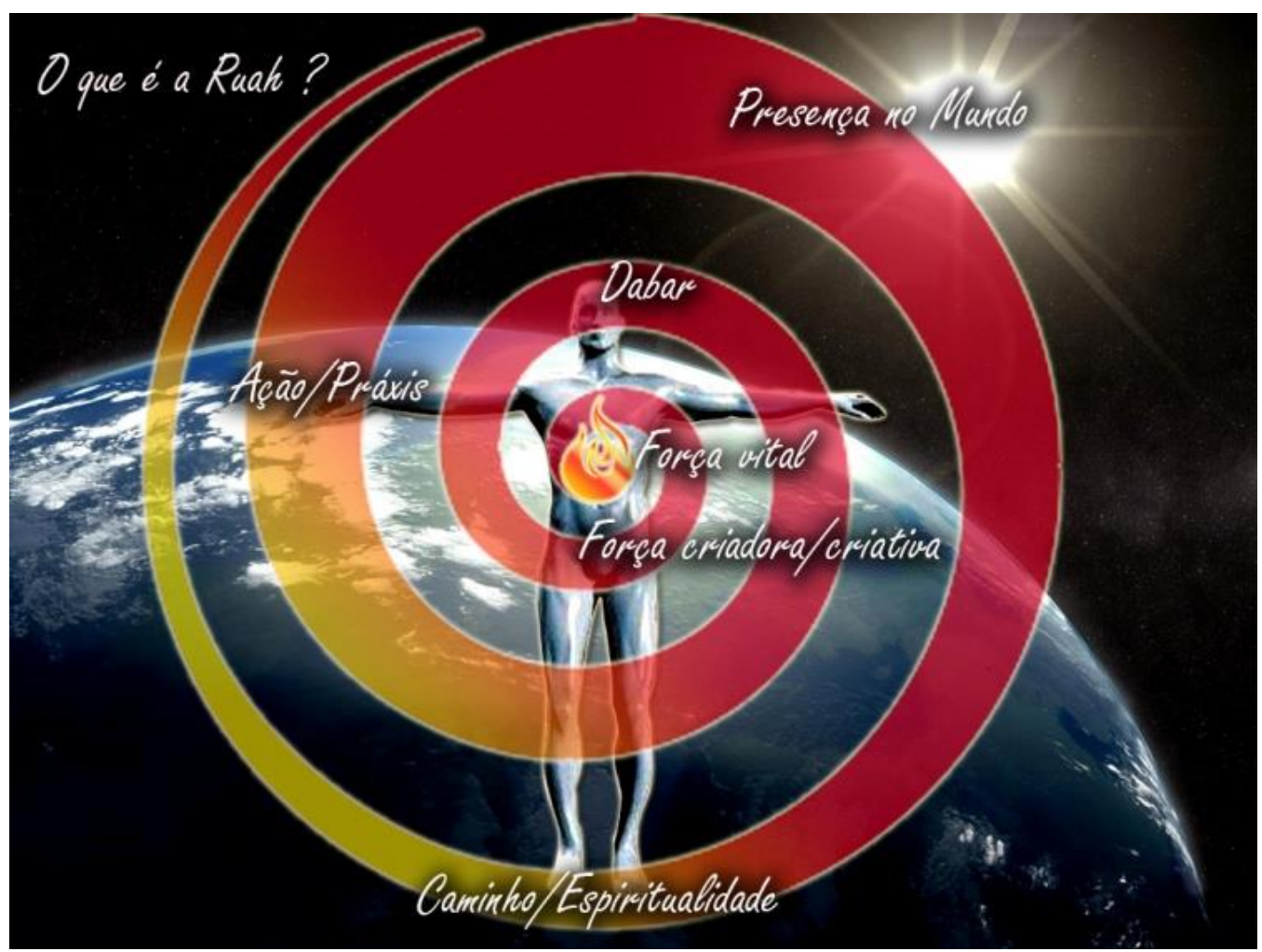

Figura 1 - Espiral da Ruah por Viviane Moreira

Cada experiência vivida por nosso corpo, na sua inteireza, razão, sentimentos, sensações nos faz experimentar na nossa história a distância ou a proximidade com a força da vida que está em nós e nos cerca. Experienciar a vida é dar espaço para viver intensamente cada possibilidade de levarmos o mundo para dentro de nosso interior onde habita o Espírito de Deus e nele fazer nossas experiências de vida. Não existem duas histórias, a do homem e a da salvação, só existe uma história onde Deus que primeiro nos amou enviou seu Filho amado para que pudéssemos entender o que é verdadeiramente ser 
humano e nos deu seu Espírito para que possamos a cada dia viver no seu amor e na sua santidade.

As experiências de vida e morte com toda a sua força, as experiências comunitárias que nos aproximam e nos faz irmãos e as experiências que herdamos, que chegaram até nós por gerações e que nos dizem quem somos, são todas estas que nos deixam vivenciar a presença de Deus em nossas vidas pela força do seu Espírito.

Nosso desafio não é entender que onde está a Igreja, está o Espírito Santo; mas sim que onde está o Espirito Santo, ali está a Igreja. Entender que, como cristãos, vivemos nossas experiências de Deus numa via de mão dupla: como Corpo de Cristo e como cristãos que vivem o Espírito de Cristo.

Fazemos a experiência no Espírito "como Igreja", na recepção dos sacramentos, na celebração da liturgia, na proclamação do Evangelho, na ação coletiva em favor do outro, na reflexão teológica, nas pastorais, nos movimentos, na oração comunitária, ou seja, em tudo que nos faz sentir um "nós". Como Igreja Corpo de Cristo, organismo vivo que sente, elabora, reflete e expressa as experiências que transformam, edificam, ou dilaceram e estratificam o Corpo da Igreja, através da sua teologia, do seus documentos. Que é feita de indivíduos, mas é maior que estes, pois é também Corpo Místico, é realidade escatológica.

Como território de passagem, o organismo vivo, que é a lgreja, também é tocado por experiências que a tomam, desalojam e abrem perspectivas para uma nova leitura da vida dessa mesma Igreja. Juntos, sentimos "como Igreja", ora acolhemos a expressão destas experiências, ora nos revoltamos diante daquelas que não são expressas e elaboradas e por isso nos parecem ficar "atravessadas" no caminhar da Igreja.

Porém, também somos indivíduos, e fazemos uma experiência pessoal no Espírito de Deus, nossa vida é marcada pelas dores, alegrias, ódios, amores, morte e nascimento. E a Igreja que é cada um de nós experimenta tudo isso à luz da nossa fé, da nossa individualidade, nossa subjetividade e liberdade. Poderíamos dizer que neste momento, sentimos "na Igreja", e quando assim o dizemos não nos referimos a um lugar, mas sim a um estar. Somos Igreja onde quer que estejamos, não podemos separar quem somos do que somos, nossa leitura da vida e das experiências que vivemos estão submetidas à nossa fé em Jesus Cristo morto e ressuscitado, mas nem sempre sentimos "como Igreja", aquilo que sentimos "na Igreja". Viver essa via de mão dupla, não é tão simples, principalmente para os leigos, somente o Espírito Santo de Deus, que move a Igreja e que inhabita em nossos corações pode realizar esta comunhão. 
O testemunho das CEB's é um convite a mergulhar nas águas profundas da reflexão do que é realmente ser Igreja, estar na Igreja e sentir com a Igreja . Essa experiência do Espírito de Deus no dia-dia do povo é um exemplo a ser seguido por todos os cristãos, estejam onde estiverem: no campo ou na cidade, no interior ou nas grandes metrópoles.

Mas como as próprias CEB's assumiram ao longo de sua história, em seu processo de maturidade, elas não são "o jeito de ser Igreja", são "um jeito de ser Igreja", que pode apontar inúmeras luzes para o caminhar de toda a Igreja.

Podemos elencar em especial:

- A proximidade com a Palavra de Deus a partir dos círculos bíblicos, dos grupos de reflexão, das paraliturgias e nos encontros pastorais. Uma partilha que tenha como prioridade o encontro da pessoa com o texto bíblico e não a simples leitura de uma ideia pré-estabelecida, como é a maioria dos círculos que são realizados em cima de cartilhas, onde o participante é uma mera voz na leitura do texto. É preciso devolver a voz ao povo, deixar que sua história entre na história bíblica, assim ele/a pode se sentir protagonista neste encontro com a Palavra.

- A comunhão e a solidariedade fraternas entre si e com os mais necessitados devem ser alicerces para a vida de comunidade, a luta pelo bem comum, pela justiça social, pela vida digna e pela igualdade de direitos para todos, são práticas primordiais para que haja vida em abundância.

- A fração do pão (eucaristia) é o momento de encontro com Jesus Cristo, em que a comunidade se apresenta como família. Pede perdão pelos erros comunitários, apresenta suas lutas, suas vitórias, seus desafios, coloca tudo em seu altar para que junto ao seu corpo seja comunhão para toda a comunidade. Esse encontro não necessita ser diário, mas todas as vezes que acontece é sempre um evento que lança a comunidade em missão, e alimenta a certeza de que o rio já corre nas terras do Reino de Deus. Para tal, a liturgia deve falar ao coração das pessoas, deve trazer a vida para o altar, deve conter símbolos, cantos e expressões que comuniquem o mistério celebrado.

- A vida ministerial precisa ter seu compromisso para com a realidade. $\mathrm{O}$ papel do leigo nas paróquias, nas pastorais e movimentos pode ser visto com maior autonomia. De que adianta ter o altar da Igreja empencado 
de ministros da eucaristia, se há doentes sem comungar, presos sem ser visitados, crianças sem ser batizadas, capelas fechadas sem celebração da Palavra e tantas outras ações que, legitimamente podem ser assumidas pelos leigos? As Comunidades de base nos apontam para o comprometimento de que somos investidos a partir de nosso batismo.

- A questão da opção pelos pobres, ainda é uma temática a ser aprofundada com mais atenção e abertura. Hoje, esta categoria abrange uma gama maior de pessoas vivendo à margem da estrutura social. A dimensão da pobreza passa por camadas ainda mais profundas do tecido social. À multidão dos que nada tem, juntam-se os transexuais, os migrantes, os sem-terra, os exilados e tantos outros. Como falar de opção, se muitos descartados nem se veem como pobres? As CEB's encontraram no jeito simples de "amar como Jesus amou", a medida acolhedora de ver em todos os rostos não só o outro, mas o mesmo Cristo.

Muito poderia ainda ter se falado sobre as contribuições das CEB's para a Igreja do Brasil hoje. O número de teólogos, padres e bispos que acompanham as CEB's é grande; no entanto, a produção teológica sobre uma experiência que marcou a história eclesiológica da Igreja do Brasil é mínima.

Produz-se muito: material de formação de lideranças, subsídios para caminhada, cartilhas para círculos bíblicos e tantos outros materiais populares. Entretanto, poucos fazem uma análise teológica do resultado destas leituras, das experiências registradas destas comunidades.

No último Intereclesial, a preocupação com a formação das lideranças das CEB's, também foi tema de debate e preocupação dos assessores. Em meio a análise de conjuntura da caminhada dos últimos 20 anos, se perguntavam: - De que formação precisam os membros das CEB's? Uma formação que ajude a desenvolver o processo de humanização ou uma formação limitada a apenas a esta ou aquela dimensão? Foram apresentadas algumas experiências de formação que tiveram êxito, dentre as quais a que se vivencia nas Escolas de Formação Missionária (Juazeiro - BA; Mogeiro - PB; Esperantina - PI; Floresta - PE; Barra - BA e Nazaré da Mata - PE). Não podemos aqui explicitar sua proposta teórico-metodológica pois ela não se apresentou de forma sistêmica. Mas sabemos, por conhecimento próprio que ela está fundada numa sólida formação teológica. 
Eclesiologia das CEB's merece ser aprofundada considerando os novos desafios que a pós modernidade nos coloca.

As conquistas que foram alcançadas por estas comunidades há quase 5 décadas merecem ser pesquisadas à luz da revelação de Deus na história e das possibilidades futuras que estas podem vivenciar.

O trabalho aqui apresentado é modesto e nem chega a ser uma gota no oceano da vida das Comunidades Eclesiais de Base, mas procura ser, pelo menos, um estímulo aos que amam a Igreja de Cristo e querem ver surgir ainda mais "comunidades de comunidades". 
6

\section{Referências Bibliográficas}

6.1

Documentos

ARQUIDIOCESE DO RIO DE JANEIRO. 11ํㅜ Plano Pastoral de Conjunto. Rio de Janeiro: ARQUIDIO, 2012.

BENTO XVI. Spe Salvi - Carta Encíclica sobre a esperança cristã. São Paulo: Paulus, 2007.

CELAM. Conclusões das Conferências do Rio de Janeiro, de Medellin, Puebla e Santo Domingo. Documentos do CELAM. São Paulo: Paulus, 2004.

CELAM. Documento de Aparecida - Texto conclusivo da V Conferência Geral do Episcopado Latino Americano e do Caribe. São Paulo: Ed. CNBB/Paulus /Paulinas. SP, 2007.

CNBB. As Comunidades Eclesiais de Base na Igreja do Brasil. Documento 25. Brasília: Edições CNBB, 1982. Disponível em $<$ http://www.cnbb.org.br/site/component/docman/cat_view/134documentos-cnbb?start=60 >. Acesso em 18/08/15.

CNBB. Plano de Emergência para Igreja do Brasil. $2^{a}$ ed. São Paulo: Paulinas, 2004.

CNBB. Plano de pastoral de conjunto: 1966-1970. São Paulo: Paulinas, 2004.

CNBB. Mensagem do Povo de Deus sobre as Comunidades Elesiais de Base. Brasília: Edições CNBB, 2010.

CNBB. Diretrizes Gerais da Ação Evangelizadora da Igreja no Brasil: 2011-2015. Brasília: Edições CNBB, 2011.

FRANCISCO. Evangelii Gaudium. Exortação Apostólica - O Anúncio do Evangelho no Mundo Atual. São Paulo: Paulus/Edições Loyola, 2013.

FRANCISCO. Carta Encíclica Laudato Si'- Sobre o cuidado da casa comum. Roma: Vaticano, 2013. Disponível em: <http://w2.vatican.va/content/francesco/pt/encyclicals/documents/papafrancesco_20130629_enciclica-lumen-fidei.html>. Acesso em 15/02/2016.

JOÃO PAULO II. Carta do papa à CNBB sobre a missão da Igreja e a Teologia da Libertação. Petrópolis: Vozes,1986. 
PAULO VI. Evangelii Nuntiandi. Exortação Apostólica do Episcopado, ao Clero, aos fiéis de toda a Igreja sobre a Evangelização no mundo contemporâneo. Disponível em: <http://w2.vatican.va/content/paulvi/pt/apost_exhortations/documents/hf_p-vi_exh_19751208_evangeliinuntiandi.html . Acesso em 05/07/16.

PIO XII. Discorsi e Radiomessaggio di Sua Santità PIO PP. XII Ai Fedeli Romani. 10 feb. 1952. Disponível em: $<$ http://w2.vatican.va/content/pius-xii/it/speeches/1952/documents/hf_pxii_spe_19520210_fedeli-romani.html>. Acesso em 22/08/2015. Site Oficial Movimento Mondo Migliore <http://www.mmmitalia.org/

SAGRADA CONGREGAÇÃO PARA A DOUTRINA DA FÉ. Instrução sobre alguns aspectos da teologia da libertação. 1984. Disponível em <http://www.vatican.va/roman_curia/congregations/cfaith/documents/rc_c on_cfaith_doc_19840806_theology-liberation_po.html>. Acesso em $09 / 02 / 2016$.

\section{2}

\section{Livros}

AGOSTINHO, Santo. A Trindade. Livro. 8, cap. 6. 4를 Eda Paulo: Paulus, 2008.

AQUINO, Maria Pilar. A teologia, a Igreja e a mulher na América Latina. Coleção Mulher, ontem e hoje. São Paulo: Paulinas, 1997.

BARREIRO, Álvaro. Comunidades Eclesiais de Base e Evangelização dos Pobres. São Paulo: Loyola, 1977.

BEOZZO, José Oscar. A Igreja do Brasil no Concílio Vaticano II 19591965. São Paulo: Paulinas, 2005.

BETTO, Frei. O que é Comunidade Eclesial de Base. $5^{\mathrm{a}}$ ed. São Paulo: Brasiliense, 1985.

BOFF, Leonardo. Como fazer teologia da libertação. Petrópolis: Ed. Vozes, 1986.

$\overline{\text { Record, }} 2008$.

Eclesiogênese: A reinvenção da Igreja. Rio de Janeiro: Ed.

. Ecologia: grito da terra, grito dos pobres. $3^{\underline{a}}$ ed. São Paulo: Ática, 1999.

Experimentar Deus: a transparência de todas as coisas. Campinas: Verus, 2002.

.; BOFF, Clodovis. Da Libertação. O teológico das libertações sócio históricas. Petrópolis: Ed. Vozes, 1985.

BROWN, Raymond Edward. A comunidade do discípulo amado. São Paulo: Paulus, 2003. 
BUSCEMI, Maria Soave. Eu, Terra do Meio. Corpo de Mulher e Leitura Popular da Bíblia. São Bernardo do Campo: Editora Nhanduti, 2007.

CÂMARA, Dom Helder. Correspondência Conciliar - Circular de número 31, datada de $1^{\circ}$ de novembro de 1963. Recife: Ed. Universitária da UFPE, 2004.

CAMARGO, Cândido Procópio Ferreira de. Igreja e Desenvolvimento. São Paulo: CEBRAP, Editora Brasileira de Ciências, 1971.

CANTALAMESSA, Raniero; GAETA, Saverio. O sopro do Espírito. São Paulo: Paulus e Ave-Maria, 1998.

CANTA POVO DE DEUS. Cancioneiro das Comunidades. São Paulo: Loyola, 1995

CARAMURU, Raimundo. Comunidade de Base: uma opção pastoral decisiva. Petrópolis: Vozes, 1967.

CASALDÁLIGA, D. Pedro. Creio na justiça e na esperança. Rio de Janeiro: Ed. Civilização Brasileira S.A, 1978.

CEBI. Leitura Orante da Bíblia. São Paulo: Paulus - CEBI (Centro Ecumênico de Estudos Bíblicos), 2001.

CEBS. Espiritualidade Libertadora: Seguir Jesus no Compromisso com os Excluídos. Secretariado Nacional do 11을 Intereclesial - CEB's. Belo Horizonte: Editora Lutador, 2004.

CESARÉIA, Eusébio de. História Eclesiástica. Cap.: XVI, Livro 5. Rio de Janeiro: Casa Publicadora das Assembleias de Deus, 1999.

CODINA, Victor. Creo em el Espíritu Santo - Pneumatologia narrativa. Espanha: Sal e Terra, 1994.

COMBLIN, José. O Espírito Santo no Mundo. $2^{a} e d$. São Paulo: Paulus, 2010.

CONGAR, Yves. A Palavra e o Espírito. São Paulo: Loyola, 1989.

. Creio no Espírito Santo 1 - Revelação e experiência do Espírito. São Paulo: Paulinas, 2005.

Creio no Espírito Santo 2 - Ele é Senhor da Vida. São Paulo: Paulinas, 2005.

DE FIORES, Stefano. A "nova" espiritualidade. São Paulo: Editora Cidade Nova/Paulus, 1999.

DELLA CAVA, R. Miracle at Joazeiro. New York/London: Columbia University Press, 1970.

DE VAUX, Roland. Instituições de Israel no Antigo Testamento. São Paulo: Editora Teológica, 2003.

DENZINGER, H. Compêndio dos símbolos, definições e declarações de fé e moral. São Paulo: Paulinas/ Loyola, 2007.

FERRARI, Alceu. Igreja e Desenvolvimento - O Movimento de Natal. Natal: Fundação José Augusto, 1968. 
FORTE, Bruno. A Igreja ícone da Trindade: breve eclesiologia. São Paulo: Loyola, 1987.

GADAMER, Hans Georg. Verdade e método. Traços fundamentais de uma hermenêutica filosófica. Petrópolis: Vozes, 1999.

GUTIÉRREZ, Gustavo. Teologia da Libertação. $6^{\underline{a}}$ ed. Petrópolis: Vozes, 1986.

KELL, Medard. Escatologia. Salamanca: Ediciones Sigueme, 1992.

LAFONT, Gislain. Imaginar a Igreja Católica. São Paulo: Ed. Loyola, 2008.

LEÃO, Jordana Gonçalves. Fragmentos de um 'diário': a correspondência pessoal de Helder Pessoa Camara (1944-1952). Recife, 2011. Dissertação de Mestrado. Faculdade de História Social e da Cultura Regional. Universidade Federal Rural de Pernambuco. Dissertação disponível em:

http://www.pgh.ufrpe.br/dissertacoes/Jordana\%20Leao.pdf> Acesso em 22 de Agosto de 2011.

LEGER. Danièle Hervieu. O Peregrino e o convertido. Petrópolis: Vozes, 2008.

LIBÂNIO, João Batista. Teologia da Revelação a partir da modernidade. São Paulo, Loyola. 1992.

LIÉBAERT, Jaques. Os Padres da Igreja [Séculos I - IV]. Volume I. São Paulo: Loyola, 2004.

MARITAIN, Jacques. Os Direitos do Homem. Rio de Janeiro: Ed. José Olympio, 1967

MAZZAROLO, Isidoro. O Clamor dos Profetas ao Deus da Justiça e Misericórdia. Rio de Janeiro: Mazzarolo Editor, 2007.

MESTERS, Carlos. Deus onde estás? Uma introdução prática à Bíblia. Petrópolis: Vozes, 2003.

MIRANDA, Mário França. A Salvação de Jesus Cristo. São Paulo: Loyola, 2004.

MOLTMANN, Jürgen. O Espírito da Vida - Uma pneumatologia integral. Petrópolis: Vozes 1999.

. Teologia da Esperança. São Paulo: Edições Loyola, 2002.

. Trindade e Reino de Deus. Uma contribuição para a teologia. $2^{\text {a }}$ Ed. Petrópolis: Editora Vozes, 2011, p.39-41.

MÜLLER, Gerhard Ludwig; GUTIÉRREZ, Gustavo. Ao lado dos pobres: Teologia da Libertação. São Paulo: Paulinas, 2014.

NETO, João Paixão; MACHADO, Alda Anunciação. Léxicon. Dicionário Teológico Enciclopédico. São Paulo: Loyola, 2003.

PADOVESE, Luigi. Introdução à Teologia Patrística. São Paulo: Loyola, 1992. 
PERALIAS, Isabel Ortega. Participação e autonomia das mulheres nas Comunidades Eclesiais de Base (Cebs). Goiás, 2014. Tese de Mestrado - Faculdade de Ciências da Religião, Universidade Católica de Goiás. Disponível em: <http://tede.biblioteca.ucg.br/tde_busca/arquivo.php?codArquivo=365> Acesso em 15/09/2014.

SANTANA, Luiz Fernando. O Espírito Santo e a Espiritualidade Cristã. Rio de Janeiro: Ed. Bom Pastor, 1999.

SCHENEIDER, Theodor (Org.). Manual de Dogmática. V. 1. $2^{\mathrm{a}}$ ed. Petrópolis: Vozes, 2002.

SICRE, José Luis. Profetismo em Israel: O profeta. Os Profetas. A mensagem. Petrópolis: Vozes, 1996.

STORNIOLO, I.; BALANCIN, E. M. Como ler o livro do Êxodo: o caminho para a liberdade. São Paulo: Paulus, 1991.

TAVARES, Sinivaldo S. (org). Memória e Profecia - A Igreja do Vaticano II. Petrópolis: Vozes, 2005.

TEIXEIRA, Faustino. A Gênese das Cebs no Brasil. Elementos Explicativos. São Paulo, Paulinas, 1988, p.73.

Comunidades Eclesiais de Base. Bases teológicas. Petrópolis: Vozes, 1988, p. 30.

TEPEDINO, Ana Maria. Encontro com a Igreja de Jesus Cristo (Eclesiologia). Coleção Iniciação Teológica. Departamento de Teologia. Rio de Janeiro: PUC/Rio: Edição Experimental, 2005.

Amor e discernimento - Experiência e razão no horizonte pneumatológico das Igrejas. São Paulo: Paulinas, 2007.

TORRINHA, Francisco. Dicionário Português - Latino. Porto: Laborando Vinces, 1939.

VARONE, Francois. Esse Deus que dizem amar o sofrimento. São Paulo: Santuário, 2001.

YUNES. Eliana. Tecendo um leitor: uma rede de fios cruzados. Curitiba: Ayamará, 2009.

VV.AA. Justiça e Profecia a serviço da vida. Texto-base do $13^{\circ}$ Intereclesial, CEBs, Romeiras do Reino no Campo e na Cidade, 7 a 11/01/2014.

\section{3}

Artigos

ALVES, Maria Jeane dos Santos. "Cidadania religiosa: uma experiência de religiosas no Nordeste brasileiro". Revista Brasileira de História das Religiões - ANPUH. Anais do II Encontro Nacional do GT História das Religiões e das Religiosidades, v. 1, n. 3. 2009. 
ARAGÃO, Gilbraz. "Inculturação da fé cristã na religiosidade popular". Revista Vida Pastoral, n. 289, março-abril, 2013.

BARREIRO. Álvaro. "As Comunidades Eclesiais de Base como modelo inspirador da nova evangelização". Revista Perspectiva Teológica, n. 24, 1992. Disponível em <http://www.faje.edu.br/periodicos/index.php/perspectiva/article/viewFile/ 894/1324>. Acesso em 24/11/2015.

BEOZZO, José Oscar. "A recepção do Vaticano II na Igreja do Brasil". In INSTITUTO NACIONAL DE PASTORAL (Org). Presença pública da Igreja no Brasil (1952-2002): Jubileu de ouro da CNBB. São Paulo, Paulinas, 2003.

BINGEMER, Maria Clara. "Comunidades Eclesiais de Base: Vida e Esperança". Site Amaivos, Notícia em Destaque, 26 abr. 2003. Disponível em: $<$ http://amaivos.uol.com.br/amaivos09/noticia/noticia.asp?cod_noticia $=19$ 03\&cod_canal=44>. Acesso em 20/08/2011.

BUYST, lone. "Beba da fonte: sobre o lugar da liturgia na espiritualidade cristã". In.: SECRETARIADO NACIONAL DO 11. INTERECLESIAL DAS CEBs. CEBs: Espiritualidade Libertadora - seguir Jesus no compromisso com os excluídos. Texto-base do 11. Intereclesial de CEBs. Belo Horizonte: Ed. O Lutador, 2004.

CALADO, Alder. "CEBs: Desafios e Perspectivas de Enfrentamento". In: ISER-Assessoria. $2^{\circ}$ Dossiê sobre o $\mathbf{1 3}^{\circ}$ Intereclesial. [s.I]: ISER, 2014. Disponivel em <www.iserassessoria.org.br/novo/arqsupload/224.docx> Acesso em 12/02/2016.

CONDEIXA, Rodrigo. "O Esquecimento Do Espírito Na Teologia Ocidental: Um Ensaio Pneumatológico. No Horizonte Da Teologia Hodierna". Revista Pós Escrito, n. 5, jan. /ago. Rio de Janeiro, 2012.

"FREIRAS tomam conta de tudo". Revista Visão, 31 jul. 1964, p. 42, Religião.

GODOY, Manuel José de. "A CNBB e o processo de evangelização do Brasil”. In INSTITUTO NACIONAL DE PASTORAL (Org). Presença pública da Igreja no Brasil (1952-2002): Jubileu de ouro da CNBB. São Paulo, Paulinas, 2003.

KUZMA, Cesar Augusto. "Da experiência à razão. A compreensão pneumatológica em Santo Agostinho". In. TEPEDINO, Ana Maria (org.). Amor e discernimento - Experiência e razão no horizonte pneumatológico das Igrejas. São Paulo: Paulinas, 2007.

MESTERS, Carlos. "Descobrir e discernir o rumo do Espírito.Uma reflexão a partir da Bíblia". In.: TEPEDINO, Ana Maria. Amor e discernimento Experiência e razão no horizonte pneumatológico das Igrejas. São Paulo: Paulinas, 2007.

MIRANDA, Mário França. "A Experiência do Espírito Santo - Uma abordagem Teológica”. Revista Atualidade Teológica, n.81, ano 30. 
MUNDO E MISSÃO. "CEBs: Comunidades Eclesiais de Base". Revista mundo e Missão, $2014 . \quad$ Disponível em <http://www.pime.org.br/mundoemissao/igrejacebs.htm> Acesso em 15/09/2014.

NEUENFELDT, Elaine G. "Diálogo entre Leitura Popular e Leitura Feminista". Revista de Estudos Teológicos, v.45, n.2, 2005.

NEVES, Sofia; NOGUERIA, Conceição. "A psicologia feminista e a violência contra as mulheres na intimidade: a (re) construção dos espaços terapêuticos". Psicologia \& Sociedade, n. 15, Jul/Dez, 2003, p.56. Disponível em: <http://www.scielo.br/pdf/psoc/v15n2/a04v15n2.pdf> Acesso em 23/12/2015.

OLIVEIRA, Pedro Ribeiro. "Catolicismo popular e Romanização do Catolicismo brasileiro". Revista Eclesiástica Brasileira, v. 36, fasc. 141, 1976.

QUEIROZ, Álvaro. "Jacques Maritain e o humanismo integral". Revista Eletrônica de Psicologia, Ano III, № 2, Ed. 3. Junho de 2010. <http://www.pesquisapsicologica.pro.br/pub06/Alvaro.htm> Acesso em 10/09/2014).

SOARES, Paulo Célio. "CEB's: um novo sujeito na vida da igreja. Temporalidades". Revista Discente do Programa de Pós-graduação em História da UFMG, v. 2, n. 1, Janeiro /julho de 2010.

SOUZA, Luiz Alberto Gómez de. "As CEBs vão bem, obrigado!". Revista Eclesiástica Brasileira, n. 60, 2000.

STEFANO, Gilberto. "Identificando os anabatistas até o século XII". Site SolaScrituraTT, Eclesiologia, abr. 2011. Disponível em $<$ http://solascriptura-

tt.org/EclesiologiaEBatistas/IdentificandoAnabatistasAteSeculoXIIGilbertoStefano.htm>. Acesso em 25/12/2015.

SUNG, Jung Mo. "Tarefas do Cristianismo da Libertação (IV): a metáfora do Éxodo". Site Adital, Mundo, 23 mar. 2011. Disponível em <http://www.adital.com.br/?n=bxx5. >. Acesso em 26/08/2011.

TEIXEIRA, Faustino. "Espiritualidade do Ecumenismo e do Diálogo Interreligioso". In.: CEBS. Secretariado Nacional do $11^{\circ}$ Intereclesial. Cebs Espiritualidade Libertadora: Seguir Jesus no Compromisso com os Excluídos. Belo Horizonte: Editora Lutador, 2004, p. 130.

. "O irrevogável desafio do pluralismo religioso". Ciberteologia Revista de Teologia \& cultura, n. 28, Ano VI.

. "Intereclesiais das Cebs: identidade em construção". Revista Perspectiva Teológica, v.28, n. 78, 1997. Disponível em $<$ http://www.faje.edu.br/periodicos/index.php/perspectiva/article/viewFile/ 894/1324>. Acesso em 05/09/2011.

2005.

"Comunidades Eclesiais de Base no Brasil". Iser Assessoria, $<w w w$.iserassessoria.org.br/novo/arqsupload/89.DOC $>$. Acesso em 08/09/2011. 
TEPEDINO, Ana Maria. "A espiritualidade do seguimento de Jesus no compromisso com os excluídos: Fora do amor não há salvação". In.: CEBS. Espiritualidade Libertadora: Seguir Jesus no Compromisso com os Excluídos. Secretariado Nacional do 11ํIntereclesial - CEB's. Belo Horizonte: Editora Lutador, 2004.

. "Das trevas da Angústia à consolação do Amor. Experiência de fé da comunidade joanina inspirada pelo Espírito Santo". In. Id. Amor e discernimento. São Paulo: Paulinas, 2007. 


\section{Anexo I}

Cartilha Mutirão

\section{MOVIMENTO DE EDUCAÇÃO DE BASE}

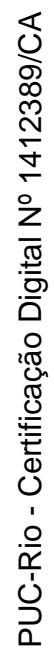

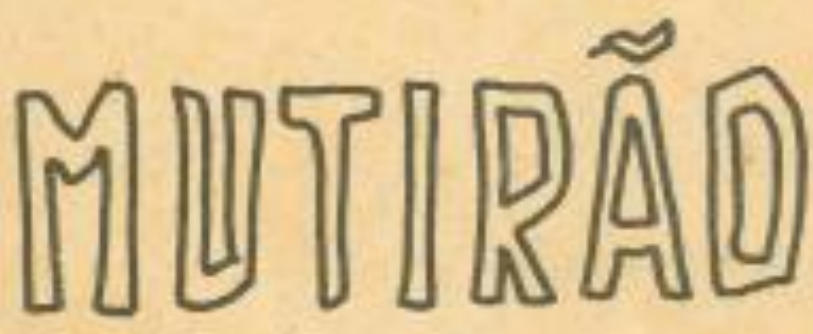

1. - livro

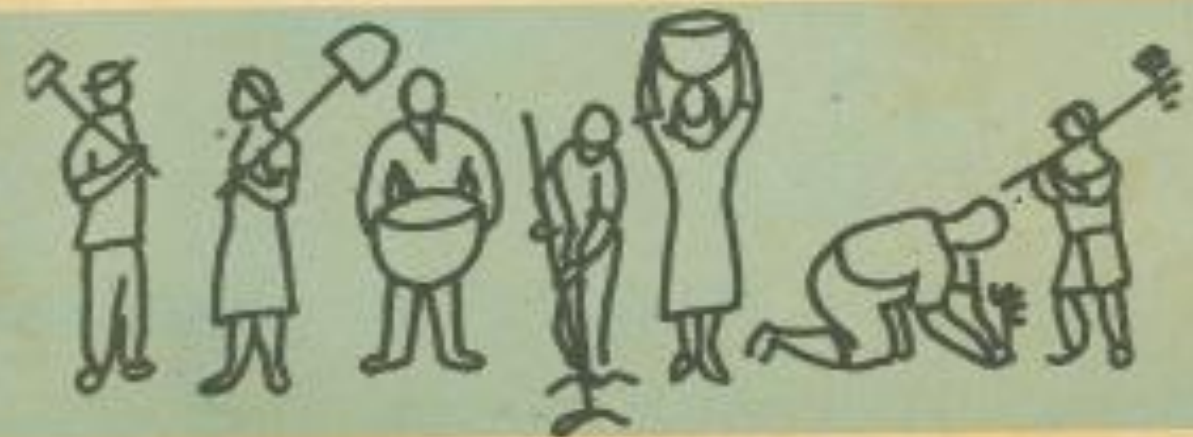




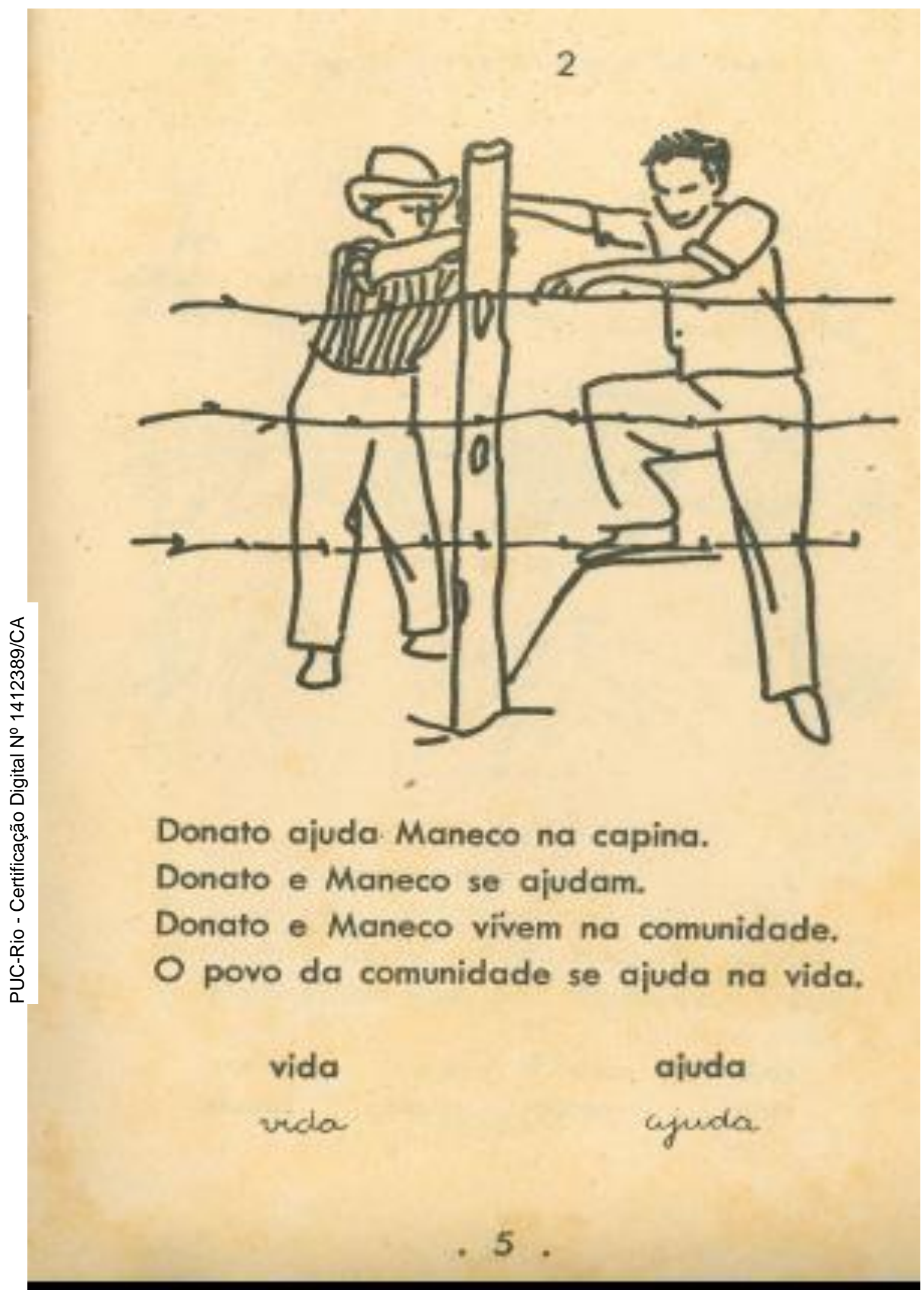




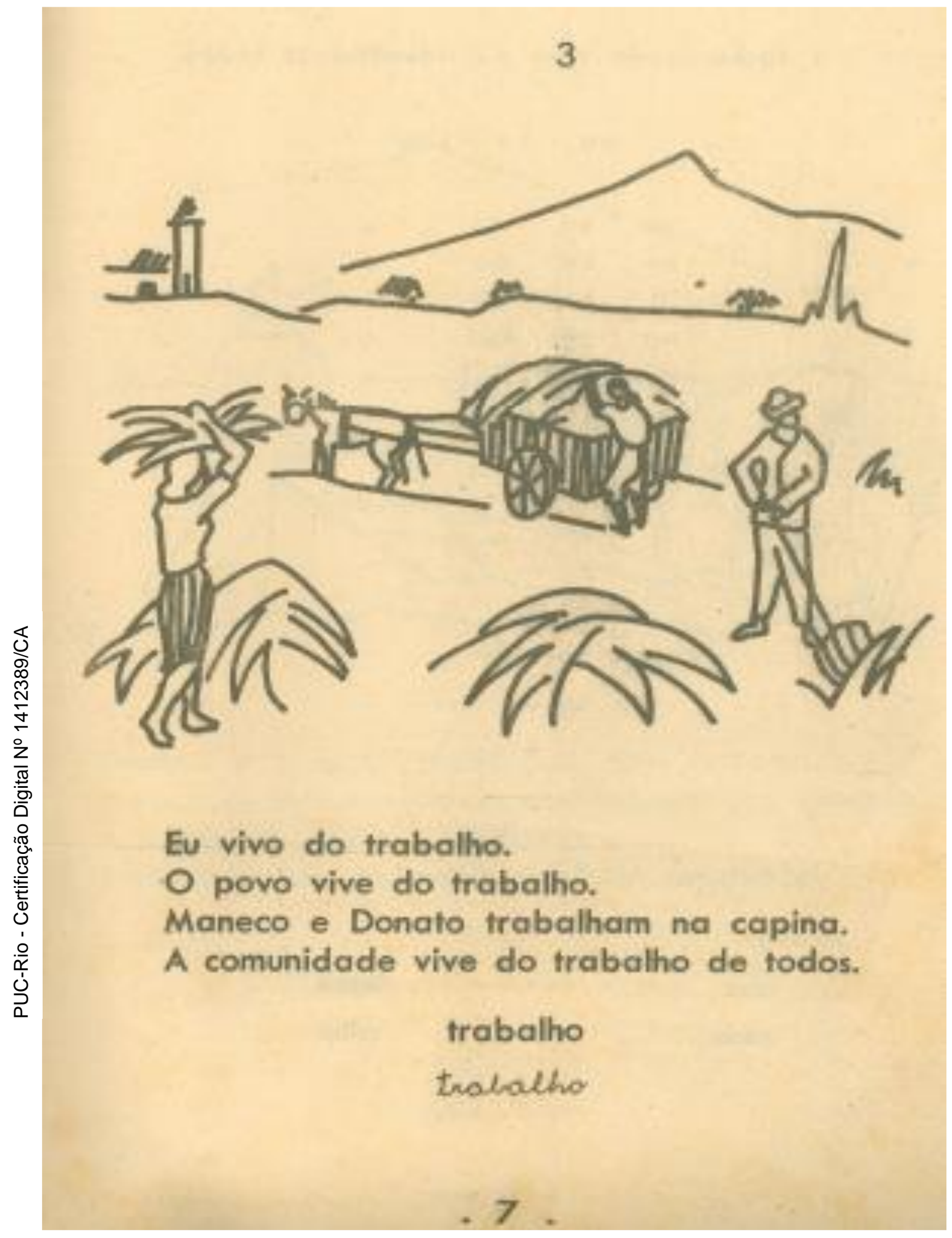


Donato tem uma roça bem perto do povoado. A comunidade vive do trabalho no roçado. Todo povo que se ajuda vive unido a methorado.

Trabalhando com a enxada, Donato cuida do roçado. A máquina ajuda o povo a ter melhor resultado. Todo povo que se ajuda vive unido a melhorado. 


\section{Anexo II}

Cartilha Viver é Lutar

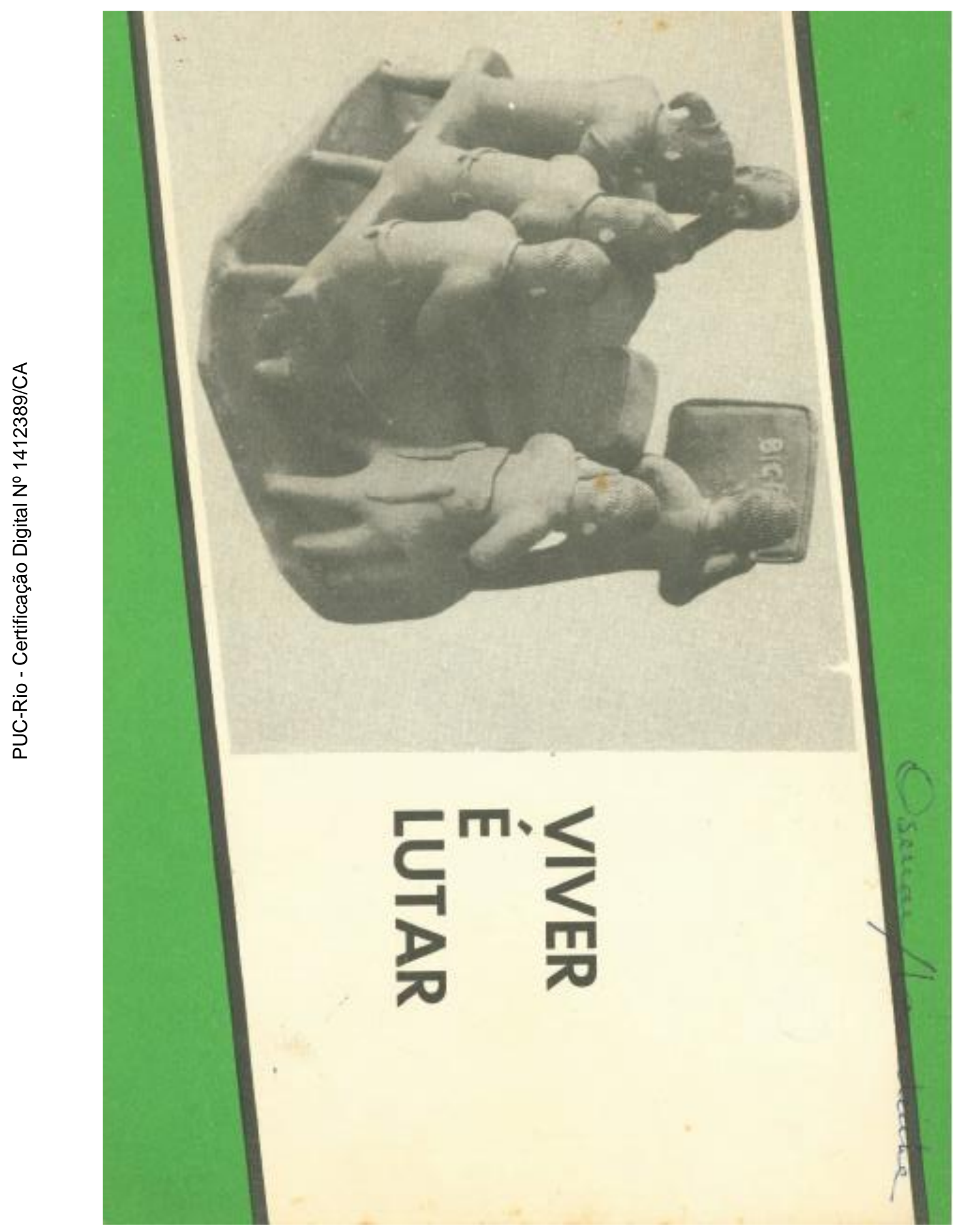




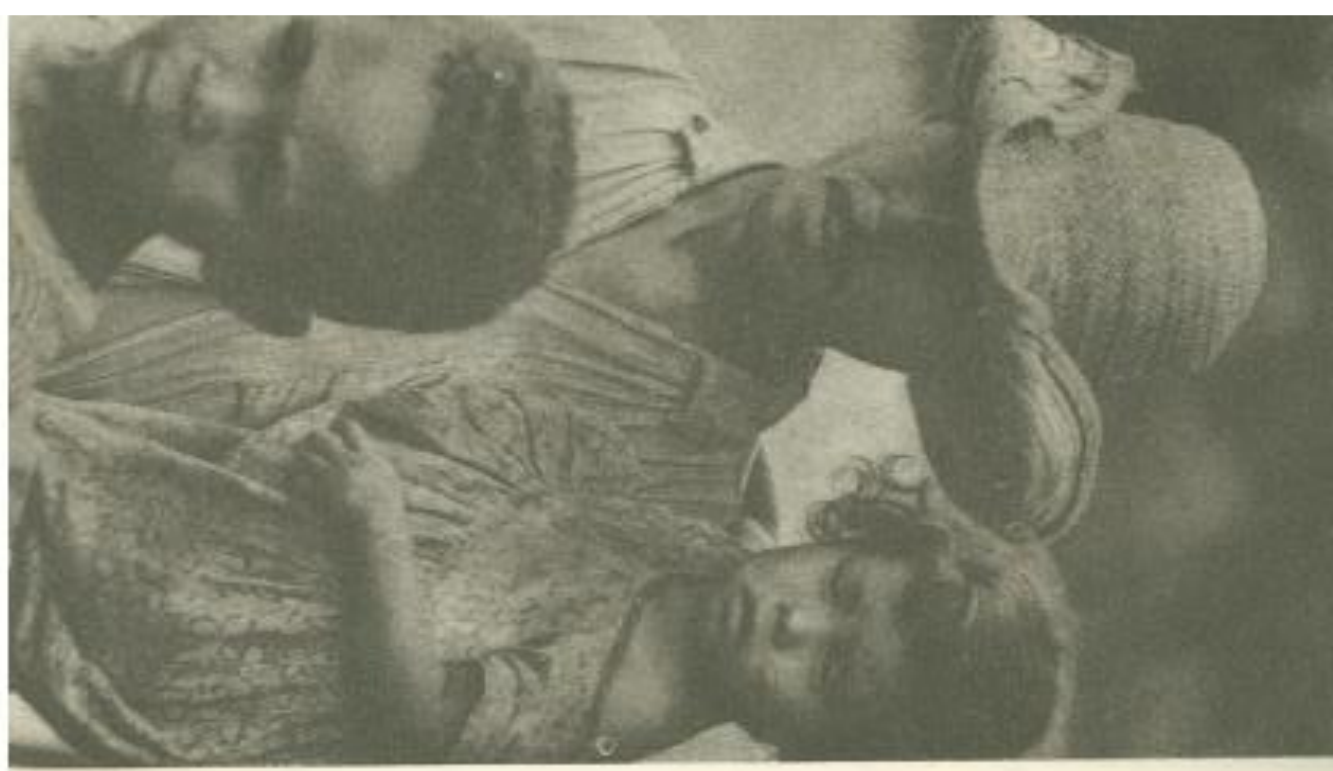

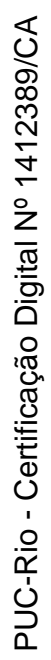

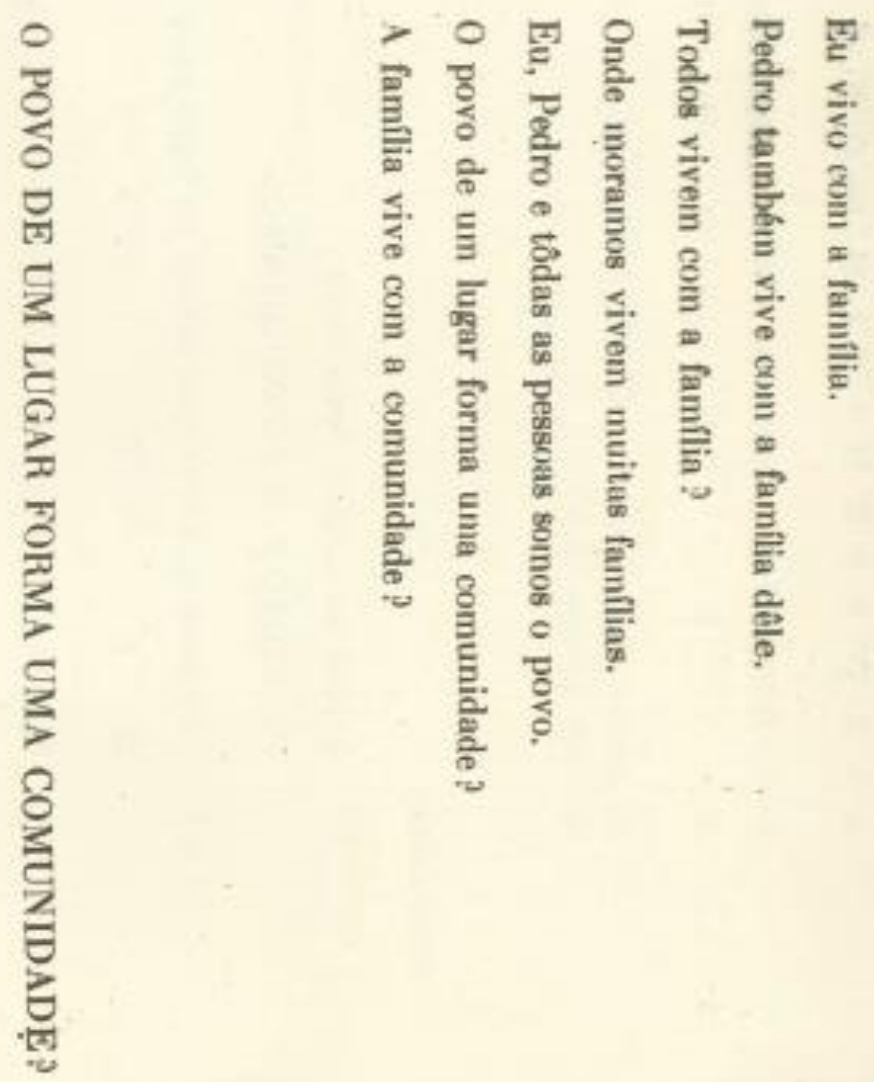




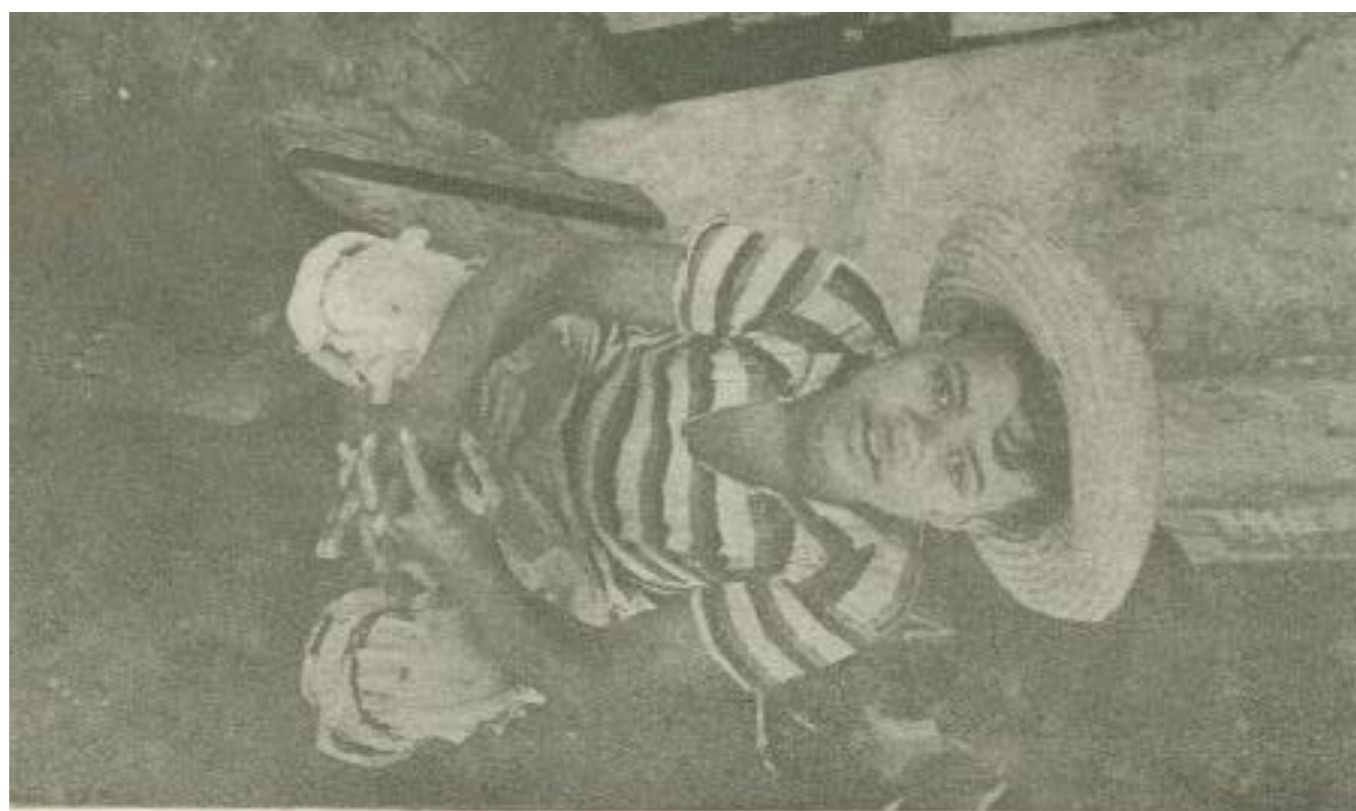

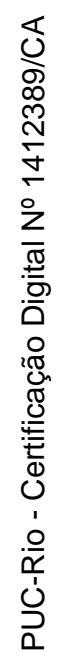

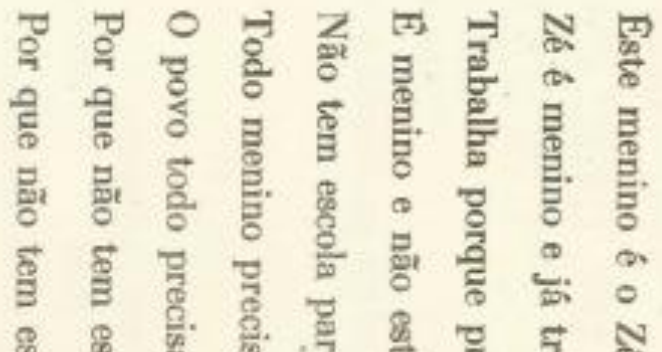

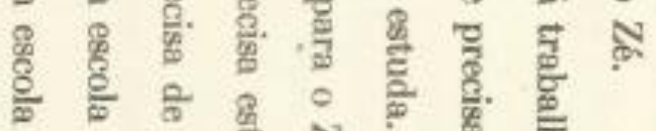

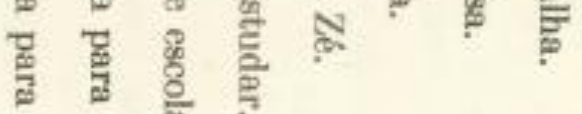

ᄒ

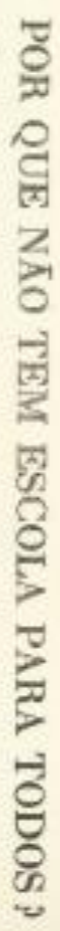

ज. 

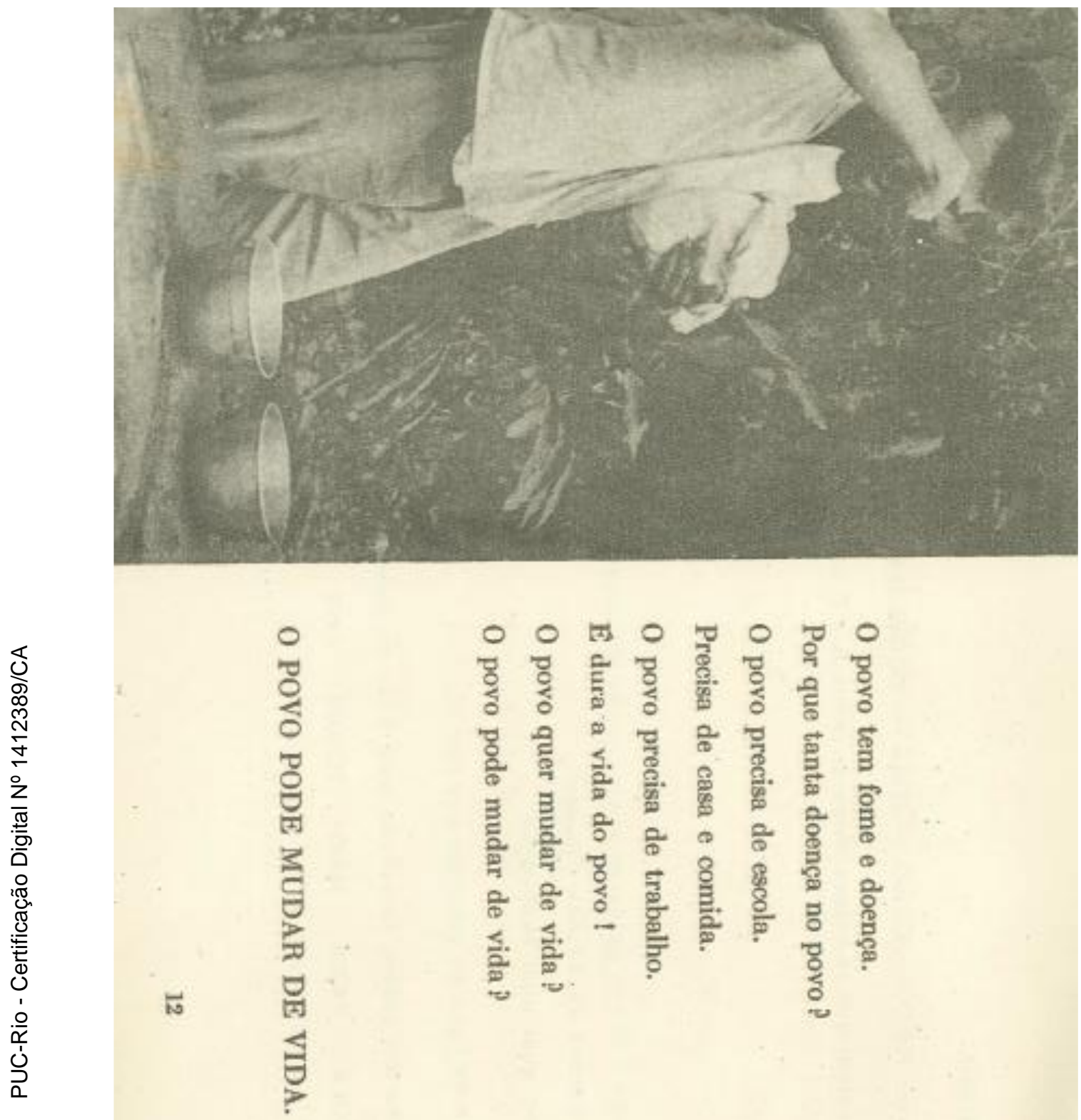


\section{Anexo III Jornal de Nízia Floresta (1964)}

RELIOIAO

\section{Freiras tomaram conta de tudo}

O perverno manicipia de Nisia Foresta, no kio Crantle do Narte, fai

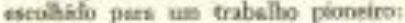

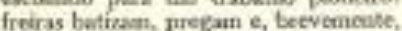

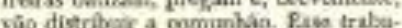

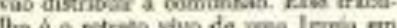
Estado de Conetin.

A expetilnola repercutia nais de. presia no rotrungeino dos que no Brast. c minitos bispos assediarain Dom Eu. Nelnio Sales, entis Administradou Apos. toliso de Nintal, oom podistos de infor. macisa. O peúpuifo Pape Phebo vi tomov contecimento da expenumei.

Ciudo começou na noito de 3 de sutubro in ato paesado, quando o povo se mowie na Praca de Matrix de Nivis Floresta, sob a hag, pore orvir Madre frani Bastios e seas ecenpanthetnas, que, ao viollio, flewent na primeira rerrats.

A peróguia nás tinha vipiria. embers tolus os doningos am padre

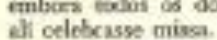

Nisia Flocesta de um monicipio localizods numa dur mais f́cteis re piltes da Zona Agresto do Ris Grande do Norte, a $60 \mathrm{~lm}$ de Natal Espalha. das pelo sev território exigtem $16 \mathrm{la}$. peos, alian de riachos em abondincia. 6 que contamente explica o fato de uprrsentar a regiso elevado inclice de expuistrewcenteic.

Nibo bil metdion nem endermeito. Drma vez por semana un dentista viota a collanis de pescadones do pôto o mácipis compreade 318

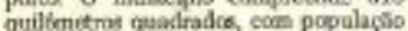
quilcenitros geadradcs

Fintùricameste, a grande now. dade de Nisia Floweota e que ela $n$ tortau * primesisa pardquia do mun. dn $\mathrm{a}$ ser ofitialmente entregse a Irei-

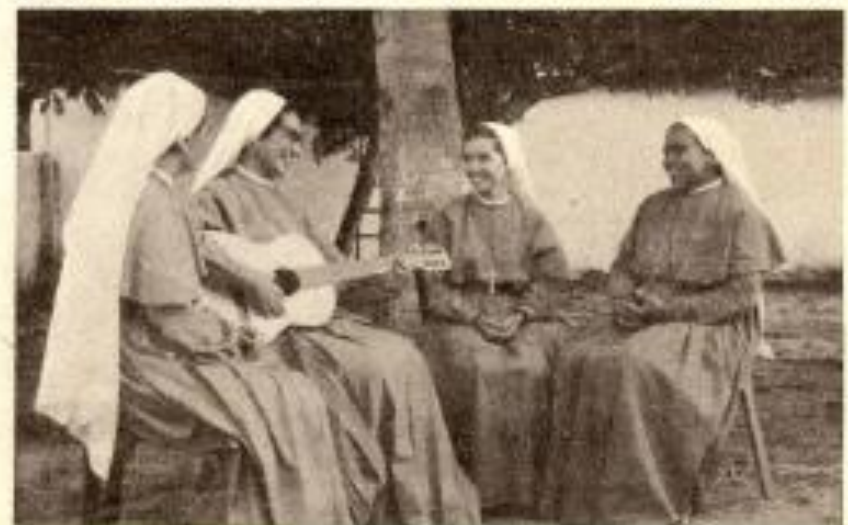

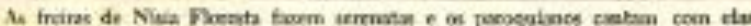
42 mo, enbora haja um vigiem of meice designido, que a wista nos fins

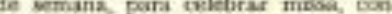
cessat e dirtvibutr a comunbas. As frei. us tìm jurisdigio ipual $\alpha$ do vigleio. Batioam ent cavos de urgencis, faien ancomenda dos moitos, pucparam os aoiver paca o cassementa, ceientami es piribialmente os movimentos de sposfalato dos lespas o movimento de ea. sais, pregam na igreja. E brim

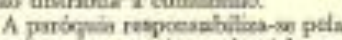

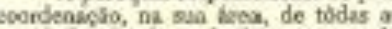
ativitlades do chamado "Xfovimento de Natar', e opdia, na medida do posil. vel a sindicalimen nurs:

Os mats oxgultogres pela rwirve. trocinento esointeal de Nish Florest. tas os mous hahitanter. Descle of mevinos Luis e Jarge, um com nove gutro com dom imes, quan explitam a organtascio da diocese e dos cocoinhas. ate a tabelius Apripino, que agars di inistabl, mas a verdade é que cada. di. on nota mais propreeso no trabalbo", Conta the ove, "ho principlo. notalur algon cokela e ficara meio descrustiaćn. Maa azora tadas soen. preendem que slas vieram apenas para servir, e gostum mito decis".

Como bos cidacte nordestina. Ni. sia Flovesta, pollckemente, dividese $\mathrm{cm}$

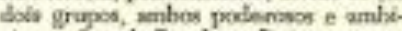
cimos o trabalto dis religiones come. el a modifiear proiundarninte o mentalidade da populargo, e co politicos, centindo a inllutricia que elus extron. a cocrunidade, tentam tirar peovelto pus us freins noda queres eom -

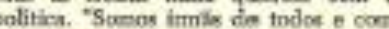
broso a toroer! Tu ere das mais pos. pors pessarn que as feeinos vehau todon nax portames de mutetra gguel" then:

A explicacio do "iallagre" de Ni. cis Floreste enconitra-be nair própirias fieiras e vo seu modo de viver

Na coxiriza retifa a lems Elex Beito Martins, maranhimse meretua de os soms. Tho boo coxhiheira quanbo juegarkesa.

A trmal eacola, com anorias 29 anes chama-se Marie joet Cardoeo Fa. mos e troberm \& pordestini $A$ mavis velhe de 37 anos, 6 a Irma Rors Sea bra Ferreira.

A quata é a madre. Coeno no cotres, fore questio de finte o rome completo: Marlene Pessos de Llas, 27 anco pernalubocan. Aerodica em to. des ponque acredita em Deras. Ama * todon poryoe ama a Deas. Serve a odoe poeque serve a Derre

Fot =illiante da Acto Cotblica noe mornos mburbanos do Recile, para vede ix depois dos walas na Facollicite

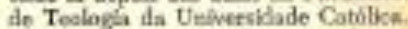

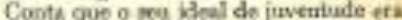

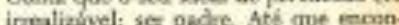

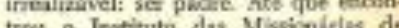
tros a lescinum das Missicniclas de

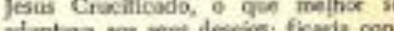

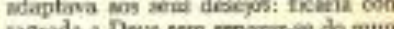
agrada a Deus sem seporar-sen do mun-

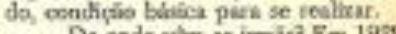
Do onde vetm as irmois? Em 1959 Dom Franciseu Carlos Barreto fundoen a. Ondem, na cidade de Ciespinas, en Sin Pudo.

fiegenise por um edatubo fledive quants an habizo dus religiosas: pooder vextirse de ardint com a époei, tes pritunds a deciro e a modisth. Dep. tro disse rrincioin, exoluiram do taif

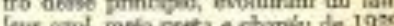

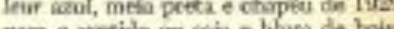
parz o vocita un satis e blusa de hoie Tem am hilwes bonito e simples, azul. marinlo, que uam es cesa e nas cerimônias religiceas.

0 esfatuto b indlexisel geanto ao espinto da congrogaclio: ecesagraçio. a Deus seme separacho of moxth, porqon 0 frimo objetiva 6 a apostolod

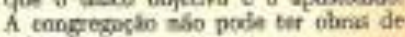
suhsielncia.

Alys, a substotondes dis freinis. en Nivia Floresta, enrektitui uma liceo

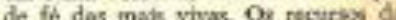
de for das mate

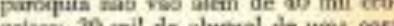
zetros: wo anil do alupel de uma casa

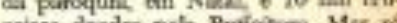

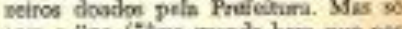
osen of jipe ("esse grande been que noa for órevido pelb Bispo-andiliar de Nowa Youk, Nonsonbor Edumant E Swanvitrom"t gastame o dinheiro toda. De gon viver metio, as freters? A madre esolice: "Vivemon di Provi-

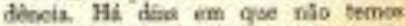
madi, mas alguma coiss apunice, trialda peb pown. Airtita no domingo passa.

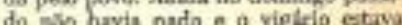
ai pars almegar. Ponoo mites das 11

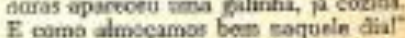

